\title{
COMÉRCIO EXTERNO E INTERNO DO BRASIL E DAS SUAS MACRORREGIÕES: UM TESTE DO TEOREMA DE HECKSCHER-OHLIN
}

\section{MÁRCIA ISTAKE}

Tese apresentada à Escola Superior de Agricultura "Luiz de Queiroz", Universidade de São Paulo, para a obtenção do título de Doutor em Ciências, Área de Concentração: Economia aplicada.

P I R A C I C A B A

Estado de São Paulo - Brasil

Junho - 2003 


\title{
COMÉRCIO EXTERNO E INTERNO DO BRASIL E DAS SUAS MACRORREGIÕES: UM TESTE DO TEOREMA DE HECKSCHER-OHLIN
}

\author{
MÁRCIA ISTAKE \\ Bacharel em Ciências Econômicas \\ Orientador: Prof. Dr. JOAQUIM J. M. GUILHOTO
}

Tese apresentada à Escola Superior de Agricultura "Luiz de Queiroz", Universidade de São Paulo, para a obtenção do título de Doutor em Ciências, Área de Concentração: Economia aplicada.

P I R A C I C A B A

Estado de São Paulo - Brasil

Junho - 2003 


\section{Dados Internacionais de Catalogação na Publicação (CIP) DIVISÃO DE BIBLIOTECA E DOCUMENTAÇÃO - ESALQ/USP}

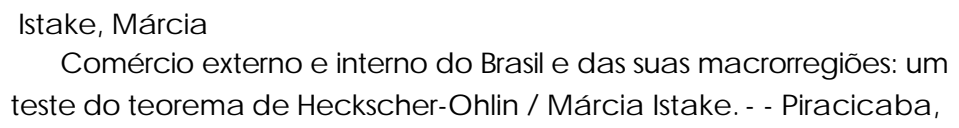

Tese (doutorado) - Escola Supenior de Agricultura Luiz de Queiroz, 2003.

Bibliografia.

1. Comércio intemacional 2. Comércio intemo 3. Economia [Brasil] 4. Economia regional 5. Insumo-produto 6. Mão de ob ra I. Título 


\section{OFEREÇO}

Aos meus pais, Augusto e Rosa, por me mostrarem que objetivos grandes podem ser atingidos e por apoiarem minhas escolhas.

DEDICO

Aos meus amores e alegrias: Milton, por incentivar minha evolução, mesmo sabendo o que isso lhe custaria;

Maria Helena, pela ausência

em minhas viagens; $\mathrm{e}$

à nossa filha que chegará em setembro

e que, juntamente comigo, compartilhou as emoções na elaboração deste trabalho. 


\section{AGRADECIMENTOS}

Ao Departamento de Economia da Universidade Estadual de Maringá, por permitir meu afastamento para cursar o doutorado, e à Capes pela bolsa de estudos que me ajudou a custear o curso.

A todos os professores que participaram da minha formação acadêmica, principalmente àqueles que diretamente influenciaram em minha escolha profissional: Prof. Laércio B. Pereira, por acreditar em minha potencialidade e por me incentivar e orientar em meus primeiros trabalhos de iniciação cientifica, e Prof. Jaime G. Trintin, que também me orientou na iniciação cientifica e na elaboração da monografia no final do curso de graduação. Agradeço ao Prof. Carlos J. C. Bacha, que me orientou durante o curso de mestrado na elaboração da dissertação. Parte da inquietação que me fez trabalhar com esse assunto em minha tese veio da defesa de dissertação, na qual o Prof. Antonio C. Lugnani me fez refletir sobre uma série de questões. Agradeço principalmente ao Prof. Joaquim J. M. Guilhoto, por me mostrar que o trabalho em grupo é altamente produtivo, principalmente nas disciplinas de Micro III e de modelos aplicados de equilíbrio geral. Professor, com você reaprendi a ensinar não exigindo e cobrando, mas sim estimulando para que as idéias deixem de ser apenas idéias e se tornem algo concreto, não importando se existem ou não todas as informações necessárias no início, pois tudo tem de ter um começo. Obrigada por nos estimular para que nossas limitações sejam superadas e por transmitir isso na conduta de suas disciplinas e na orientação dos trabalhos.

Agradeço à professora Heloisa Burnquist, que no decorrer de sua disciplina levou ao meu conhecimento as teorias que foram testadas neste trabalho. Agradeço a você e também às professoras Silvia de Miranda e Ana Kassouf, pelo tempo que dedicaram 
lendo as versões anteriores deste trabalho, bem como pelas sugestões que ajudaram no ganho qualitativo do mesmo.

Durante o curso de doutorado tive a oportunidade de conhecer e conviver com pessoas que acrescentaram muito em minha vida, direta e indiretamente, e me ajudaram de alguma forma: Casemiro, Paulo Martins, Estevão, Patrícia, Cândida e Jaenes, Cleise e Emerson, Marcos, Ricardo e Alexandre (Conchas).

Agradeço a Esalq e a seu idealizador, Luiz de Queiroz, por possibilitarem minha formação tanto no mestrado quanto no doutorado e, principalmente, ao Departamento de Economia, através de seus professores e funcionários. Agradeço diretamente a colaboração recebida das seguintes pessoas: Maieli, Helena, Pedro, Ligiana, Elenice, Álvaro, Márcia, Cristiane e Fernandinho. No Cepea agradeço à Luciane, à Ana Paula e à Mariana. Graças a minha passagem por essa escola pude conhecer e conviver com pessoas maravilhosas tanto no mestrado quanto no dourado, algumas das amizades que fiz aqui me acompanharão, tenho certeza, por toda a minha vida.

Agradeço a minha família que sempre me ajuda diretamente na batalha do dia a dia: Marcelo, Mauricio, Marisa, Juvelina, José, Ana Marta, Liri e Rosana, com a ajuda e carinho de vocês tudo fica bem mais fácil.

Agradeço às irmãs do Cenáculo Nossa Senhora de Lourdes que acolheram a mim e a minha família, durante o tempo que permaneci em Piracicaba. 


\section{SUMÁRIO}

Página

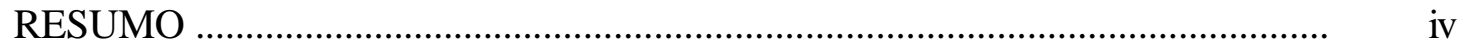

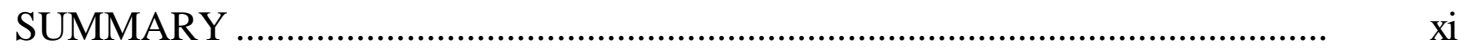

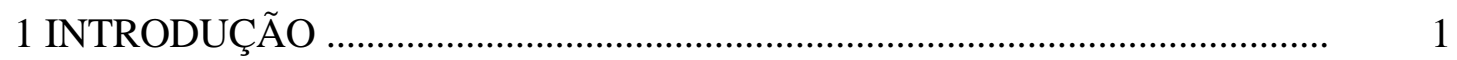

2 ECONOMIA BRASILIERA, DESIGUALDADES REGIONAIS E COMÉRCIO EXTERNO E INTERNO ......................................................... 4

2.1 Economia brasileira na década de 90.................................................................... 4

2.2 Desigualdades regionais .......................................................................... 10

2.3 Comércio exterior ...................................................................................... 18

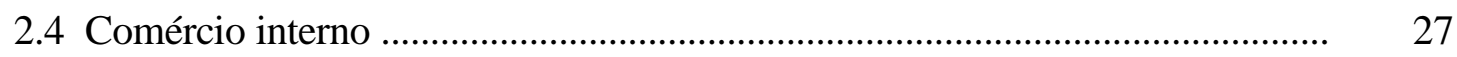

3 REVISÃO DE LITERATURA ……....................................................... 34

3.1 Teorias de comércio internacional ................................................................ 34

3.1.1 O desenvolvimento das principais teorias .................................................. 34

3.1.2 A teoria de Heckscher-Ohlin .................................................................. 37

3.1.2.1 Teorema de Heckscher-Ohlin ..................................................................... 39

3.1.2.2 Demonstração e comprovação do teorema de Heckscher-Ohlin ................... 42

3.1.2.3 A determinação da abundância relativa dos fatores ......................................

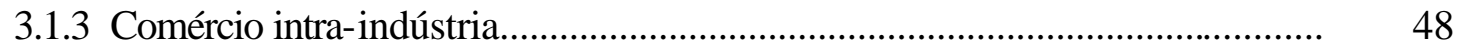


3.2 Trabalhos empíricos desenvolvidos que testam a validade do teorema de Heckscher-Ohlin

4 METODOLOGIA E FONTE DOS DADOS …………....................................... 69

4.1 Metodologia dos modelos insumo-produto nacional e regional .......................... 69

41.1 Modelo insumo-produto nacional ..................................................................... 69

4.1.2 Modelos de insumo-produto regional, inter-regional e intra-regional ............. $\quad 74$

4.1.2.1 Revisão dos modelos insumo-produto regionais .......................................... 78

4.1.3 Estrutura básica de um modelo inter-regional para duas regiões .................... 82

4.2 Metodologia utilizada para testar a validade do teorema de Heckscher-

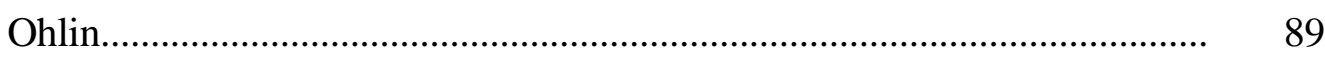

4.3 Tratamento dos dados ........................................................................ 92

4.3.1 Fonte dos dados utilizados na construção das matrizes inversas de Leontief regionais e nacionais.

4.3.2 Construção da matriz R: nacional e regionais

4.3.3 fonte e tratamento dos dados utilizados na construção das matrizes C.............. 100

5 ANÁLISE DOS RESULTADOS .................................................................... 104

5.1 Teste de validade do teorema de Heckscher-Ohlin ............................................. 104

5.1.1 Teste de validade do teorema de Heckscher-Ohlin para o comércio externo do Brasil

5.1.2. Teste de validade do teorema de Heckscher-Ohlin para o comércio externo das regiões.

5.1.3. Teste de validade do teorema de Heckscher-Ohlin para o comércio interno observado entre as macrorregiões 
6 CONSIDERAÇÕES FINAIS

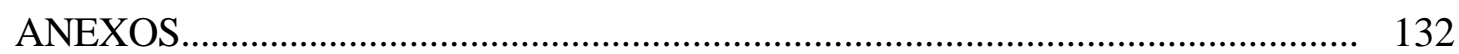

REFERÊNCIAS BIBLIOGRÁFICAS .......................................................... 140 


\section{COMÉRCIO EXTERNO E INTERNO DO BRASIL E DAS SUAS MACRORREGIÕES: UM TESTE DO TEOREMA DE HECKSCHER-OHLIN}

Autora: MÁRCIA ISTAKE

Orientador: Prof. Dr. JOAQUIM J. M. GUILHOTO

\section{RESUMO}

O objetivo deste trabalho foi avaliar, com base no padrão de comércio externo e interno brasileiro, se a especialização da produção no Brasil e nas macro-regiões encontra-se de acordo com a dotação relativa de fatores, ou se há outras questões que expliquem a localização da produção. A fundamentação teórica veio do teorema de Heckscher-Ohlin, mais especificamente da abordagem da qualificação da mão-de-obra e do comércio intra-indústria. $\mathrm{O}$ teorema de Heckscher-Ohlin foi confirmado para os trinta tipos de comércio externo observados no trabalho, e pôde-se verificar um comportamento semelhante entre os resultados obtidos para o Brasil, como um todo, e aqueles conseguidos para as suas regiões. No comércio observado entre o Brasil e as regiões e a Ásia, os Estados Unidos, a União Européia e o resto do mundo, a dotação de fatores constatada foi de mão-de-obra não qualificada. Considerando apenas o comércio do Brasil e das regiões com o Mercosul, pôde-se verificar que o Brasil e as regiões apresentaram abundância relativa de mão-de-obra qualificada. Com relação aos resultados para o comércio intra-indústria, dos 30 dimensionamentos efetuados para o 
comércio exterior, apenas em três casos o comércio interindústria não foi observado: no comércio do Brasil, do Sudeste e do Sul com o Mercosul. Pode-se sugerir, então, que, na relação entre o Brasil e as macrorregiões e seus principais parceiros comerciais no mercado mundial, o comércio interindústria foi observado na maior parte dos casos, confirmando, assim, os resultados verificados no teorema de Heckscher-Ohlin. $\mathrm{Na}$ análise dos testes do teorema de Heckscher-Ohlin realizados para o comércio interno entre as regiões do Brasil, pôde-se verificar que a validade do teorema foi confirmada para quatro das cinco regiões consideradas. Somente para o comércio verificado entre o Nordeste e as demais regiões o teorema não foi constatado. A região Sudeste foi considerada como relativamente abundante em mão-de-obra qualificada, enquanto as demais regiões se apresentaram como relativamente abundante em mão-de-obra não qualificada. O comércio intra-indústria somente foi observado, no mercado doméstico, entre macrorregiões, para as relações comerciais do Nordeste com o Centro-Oeste. Com base nos resultados verificados para o teorema de Heckscher-Ohlin, pode-se sugerir que a dotação diferenciada de fatores foi importante determinante da especialização da produção, no Brasil e nas regiões, para o comércio no mercado mundial e doméstico. O dimensionamento do comércio intra-indústria confirma os resultados observados do teorema de Heckscher-Ohlin para a quase totalidade dos casos analisados. Cabe destacar que, na revisão bibliográfica realizada para a elaboração deste estudo, não se observou trabalhos que já tivessem testado a validade do teorema de Heckscher-Ohlin para os comércios externo e interno, considerando as macrorregiões. $\mathrm{O}$ que se verificou foram trabalhos que consideravam o Brasil como um todo. Esses testes regionais somente foram possíveis de serem realizados em função do modelo inter-regional que foi construído por Guilhoto et al (2003), bem como das informações detalhadas sobre importação e exportação, publicadas pelo Ministério do Desenvolvimento da Indústria e do Comércio - MDIC - (Brasil, 2003) e pelos microdados da Pesquisa Nacional por Amostra de Domicilio - PNAD - (IBGE, 1999a). 


\title{
DOMESTIC AND INTERNATIONAL TRADE OF BRAZIL AND ITS MACROR REGIONS: A TEST OF THE HECKSCHER-OHLIN THEOREM
}

\author{
Author: MÁRCIA ISTAKE \\ Adviser: Prof. Dr. JOAQUIM J. M. GUILHOTO
}

\section{SUMMARY}

The aim of this study was to evaluate, based on the trade procedures for the external and internal Brazilian trade, if the production especialization in Brazil and in macro-regions is according to the relative allotment of factors, or if there are other questions that explain the production localization. The theoritical basis came from Hecksscher-Ohlin, more specifically, from the assessment of the labor qualification and from the trade intra-industries.The theorem of Heckscher-Ohlin was confirmed for the 30 (thirty) kinds of external trade observed, at work, and it was noticed a similar behavior among the results obtained for Brazil, as a whole, and the ones obtained for its regions. In the trade evidenced among Brazil and regions of Asia, the United States, the European Union and the rest of the world, the allotment of factors establihed was the one of non-qualified labor. Considering Brazil's trade and of the regions with MERCOSUL alone, it was noticed that Brazil and the regions offer relative abundant qualified labor. Regarding the results abtained from for the trade intra-industries, of the 30 outlinings for the external trade, only in three cases the intra-industry trade was not 
observed: in the Brazilian market, of the South and Southeast with the MERCOSUL. It can be suggested, then, that in the trade analyzed between Brazil and the macro-regions and their main business partners in the international market the trade intra-industries was observed in most cases, therefore, confirming the results verified in the theorem of Heckscher-Ohlin. In the test analysis of the theorem of Heckscher-Ohlin, carried out for the domestic market among ther egions in Brazil, it was noticed that the validity of the theorem was confirmed for four out of the five regions considered. Only between the Northeast and the other regions, the theorem was not evidenced. The Southeastern region was considered relately rich in qualified laborforce, whereas the other regions presented as relatively abundant in non-qualified labor. The intra-industry trade was only observed, in the domestic market among macro-regions, for the business relations of the Northeast and the Midlle-west. Based on the results obtained for the theorem of Heckscher-Ohlin, it can be suggested that the different allotment of factors was an important determiner of the production especialization, in Brazil and in the regions, either for the domestic as for the international markets. The outlining of the intraindustry trade confirms the results observed of the theorem of Heckscher-Ohlin, for almost all of the cases analyzed. It is worth pointing out that in the bibliographic review carried out in order to do this study it was not observed studies which had tested the validity of the theorem of Heckscher-Ohlin for the internal and external trade, considering the macro-regions. What was evidenced were the studies done considering Brazil as a whole. These regional tests were only possible to be carried out for the regions making use of the inter-regional model which was constituted by Guilhoto et al (2003), as well as of the detailed information about importation and exportation, published by the Ministery for the Development of the Industry and Commerce -MDIC(Brasil, 2003) and by the microdata of the National Research by Domicile Sample PNAD- (IBGE, 1999a). 


\section{INTRODUÇÃO}

O objetivo deste trabalho foi avaliar, com base no padrão de comércio exterior e inter-regional brasileiro, se a especialização da produção no Brasil e em suas regiões se encontra de acordo com a sua dotação relativa de fatores, ou se há outras questões que explicam a localização da produção. A fundamentação teórica veio da teoria de Heckscher-Ohlin, mais especificamente da abordagem da qualificação da mão-de-obra, adotada após a constatação do paradoxo de Leontief.

Uma questão que se procura responder freqüentemente, em comércio internacional, diz respeito à localização da produção. Para que essa questão possa ser respondida, faz-se necessário verificar quais seriam os fatores responsáveis pela distribuição da produção mundial e regional. Muitos estudos buscam respostas para tais questões (alguns deles verificados neste trabalho) na diferença de dotação de fatores existentes nos países e em regiões. De acordo com esses estudos, o país ou região que detém relativamente maior abundância em um dos fatores teria vantagem na especialização da produção de bens que utilizam em seu processo produtivo um volume maior do mesmo. Essa é a pressuposição do teorema de Heckscher-Ohlin, que foi testado neste trabalho para o comércio realizado entre o Brasil e suas macrorregiões e seus principais parceiros no comércio internacional, e também para o comércio realizado internamente entre tais regiões.

Seguindo a linha de raciocínio dos trabalhos que buscam a resposta da distribuição da produção na dotação relativa de fatores existentes nas economias, os países e as regiões subdesenvolvidos e em desenvolvimento deveriam, então, se especializar no comércio de bens intensivos em recursos naturais e em mão-de-obra de baixa qualificação, observando a hipótese de que esses fatores seriam abundantes em tais 
economias. Já os países e as regiões mais desenvolvidos, na hipótese de abundância relativa de capital e de mão-de-obra qualificada, deveriam, então, especializar-se na produção de bens intensivos nesses fatores de produção.

A questão que se procurou responder neste trabalho foi se o Brasil poderia apresentar uma especialização na produção diferenciada, comparando sua comercialização com os diferentes blocos e países considerados no estudo.

Como se pôde observar na presente pesquisa, o Brasil apresenta dimensões continentais que se caracterizam por fortes desigualdades de renda e de produto nas regiões com um núcleo economicamente mais desenvolvido, associado a regiões deprimidas e com fraco desempenho econômico. Essas disparidades podem implicar dotação relativa de fatores diferenciada nas regiões? Caso a resposta tenha sido afirmativa, uma outra questão que se levantou foi a seguinte: há uma especialização na produção nas regiões de acordo com tal dotação de fatores?

A hipótese inicial deste trabalho foi que o Brasil, como um todo, e suas macrorregiões têm abundância relativa, frente ao comércio mundial, de mão-de-obra não-qualificada. $\mathrm{Na}$ análise das regiões, esperou-se que o Sudeste apresentasse abundância relativa em mão-de-obra qualificada e que fosse exportador de bens intensivos neste fator de produção, e que as demais regiões exportassem bens intensivos em mão-de-obra de menor qualificação e importassem bens intensivos na utilização de mão-de-obra qualificada.

Uma outra questão que se levanta na teoria de comércio internacional é a seguinte: qual a justificativa para a existência de comércio entre regiões ou países com dotação semelhante de fatores? Para tentar responder a essa questão, alguns trabalhos foram desenvolvidos, buscando justificar o comércio com base na diferenciação de produtos e nas economias de escala. Com isso, eles esperam que haja um comércio mais intensivo entre segmentos de um mesmo ramo industrial, denominado comércio intraindústria. Isso difere da hipótese central do teorema de Heckscher-Ohlin, segundo a qual se espera que haja comércio entre segmentos diferenciados, denominados comércio interindústria. $\mathrm{O}$ comércio intra-indústria também foi dimensionado neste trabalho, para 
os mesmos tipos de comércio observados nos testes do teorema de Heckscher-Ohlin. Os seus resultados confirmarão, ou não, os observados para o teorema de Heckscher-Ohlin.

Este trabalho é composto de seis capítulos, incluindo esta introdução. Um panorama da economia brasileira na década de 90 foi traçado no próximo capítulo, juntamente com a análise de algumas desigualdades regionais e do comportamento do comércio interno e externo. O capítulo três mostra a evolução das teorias de comércio internacional que buscam justificar os motivos que levam os países a comercializarem. Neste capítulo, a teoria de Heckscher-Ohlin e do comércio intra-indústria encontram-se descritas em detalhes, assim como a revisão de alguns trabalhos já realizados, com o objetivo de testar a validade do teorema de Heckscher-Ohlin. O capítulo quatro tratou da metodologia empregada no trabalho. Um esboço geral sobre a forma como os dados e suas fontes foram tratados são também objetivos desse capítulo. A análise dos resultados foi realizada no capítulo cinco e as considerações finais do trabalho são apresentadas no capítulo seis. 


\section{ECONOMIA BRASILEIRA, DESIGUALDADES REGIONAIS E COMÉRCIO EXTERNO E INTERNO}

Este capítulo tem como objetivos: mostrar um breve relato da evolução da economia brasileira na década de 90, através da análise de alguns agregados macroeconômicos; relatar algumas diferenças regionais, principalmente em relação ao mercado de trabalho; e verificar o comportamento do comércio externo e interno. Os três últimos aspectos, mercado de trabalho e comércio externo e interno, foram observados em maiores detalhes por serem importantes objetos de estudo neste trabalho.

\subsection{Economia brasileira na década de 90}

A economia brasileira na década de 80 passou por um período de instabilidade econômica e de ausência de crescimento do produto interno, de acordo com Neri et al. (2000). Era uma economia considerada fechada para o fluxo de comércio e de capitais internacionais, tinha o Estado como produtor de bens e serviços e apresentava problemas com a inflação. No decorrer da década de 90, a economia brasileira passou por importantes transformações nessas áreas. No período, passou a ser uma economia mais aberta, com redução da proteção comercial e liberalização dos fluxos de capitais e, também, œm a presença do Estado reduzida como produtor de bens e serviços, devido aos processos de privatização. Pôde contar com o controle do processo inflacionário, que se deu a partir do Plano Real, o qual se baseou em uma âncora cambial, respaldado pela abertura comercial e financeira.

Essas mudanças tiveram algumas implicações no que diz respeito ao ritmo e à estrutura de crescimento da economia. De acordo com os dados da Figura 1, pode-se verificar que, nos primeiros anos da década de 90, o PIB brasileiro se encontrava 
estacionado. A partir de 1993, e mais intensamente a partir da estabilização de junho de 1994, esse processo foi revertido e pôde-se verificar um crescimento da economia até 1997. No ano de 1998, a partir da crise asiática, da crise russa e da consequiente crise financeira internacional, ocorreu uma interrupção do crescimento econômico, que vinha sendo observado no Brasil a partir de 1993. Nos anos de 2000 e 2001, a economia brasileira voltou a apresentar sinais de recuperação, e o PIB, a apresentar taxas de crescimento positivas.

Quando se observa a evolução, na década de 90, do PIB per capita, pode-se verificar que ele apresentou uma trajetória crescente, de acordo com a Figura 3, com queda nos anos de 1992, 1998 e 1999. Essa redução nos últimos anos da década encontra-se vinculada à queda observada no PIB, ocasionada, principalmente, pela crise no mercado financeiro internacional. O PIB per capita apresentou uma taxa de crescimento positiva de 13\% no período 1990-2001. Cabe ressaltar, entretanto, que esse crescimento não significa melhoria no rendimento ou na qualidade de vida da população brasileira. Essa constatação exige uma investigação mais aprofundada, através da análise de outras variáveis, que não são objetivos do presente trabalho.

Juntamente com as modificações internas, a década de 90 foi marcada pelo aumento do investimento estrangeiro no Brasil. Na Figura 2, observa-se que, no último qüinquiênio da década de 90, o investimento estrangeiro total aumentou, no Brasil, passando de um montante aproximado de 5 bilhões em 1995 para um em torno de 33 bilhões de dólares em 2000.Vale lembrar que a taxa de juros, mantida alta no período, foi responsável pela entrada do capital especulativo no país, que se encontra computado nos demais ingressos ${ }^{1}$ na Figura 2. Uma parcela dos ingressos do investimento estrangeiro foi destinada à aquisição de empresas que passaram pelo processo de privatização. Tal fato pode ser constatado na Figura 2, onde se verifica que esse tipo ingresso cresceu no período em questão.

Além da maior entrada do capital externo, uma outra transformação pela qual passou a economia brasileira nos anos 90 foi provocada pela abertura econômica e pela

\footnotetext{
${ }^{1}$ Esse item inclui as operações com moeda nacional, as mercadorias, as conversões e os reinvestimentos.
} 
valorização da moeda nacional frente ao dólar. Com relação à valorização cambial do real frente ao dólar, na Figura 6 verifica-se que a paridade das duas moedas ocorreu no ano de 1995, e teve um considerável salto no ano de 1999, quando houve uma grande desvalorização do real frente ao dólar, em decorrência da crise no mercado financeiro internacional.

Com base nos dois fatores acima observados, abertura comercial e valorização do real, pôde-se observar, no país, um aumento da participação da importação de máquinas e de equipamentos, conforme demonstra a Figura 4. Acredita-se que esse aumento, em parte, possa ser justificado pela maior tecnologia incorporada a tais produtos importados. O impacto da abertura fez-se sentir, também, em outros aspectos da estrutura organizacional da economia brasileira, como ressaltam Áurea \& Galvão (1998, p.7) “A configuração das principais cadeias produtivas vem sendo modificada (...), seja no redesenho das estruturas organizacionais das firmas, seja na substituição dos componentes, partes e peças nacionais por importadas, seja na incorporação de novas tecnologias, com ênfase nas derivadas do segmento da microeletrônica /informática".

Para observar como os setores da economia doméstica sentiram as transformações pelas quais o país passou na década de 90, foram elaboradas a Tabela $1 \mathrm{e}$ a Figura 5. Na Tabela 1, doserva-se a participação da agropecuária, da indústria e dos serviços no PIB do Brasil. Verifica-se a grande importância do setor de serviços, respondendo por aproximadamente $56 \%$ do PIB, seguido da indústria e da agropecuária com $36 \%$ e $8 \%$ em média, respectivamente. A participação desses setores, ao longo do período, manteve-se praticamente constante, não se observando, portanto, modificações com relação àimportância deles na economia brasileira nos anos 90.

A análise da Figura 5 permite constatar a taxa de crescimento do PIB, por setor, no período de 1990 a 1999, no Brasil. Verifica-se que, mesmo com todas as transformações pelas quais a economia brasileira passou, todos os segmentos apresentaram uma taxa de crescimento positiva nos anos 90. 


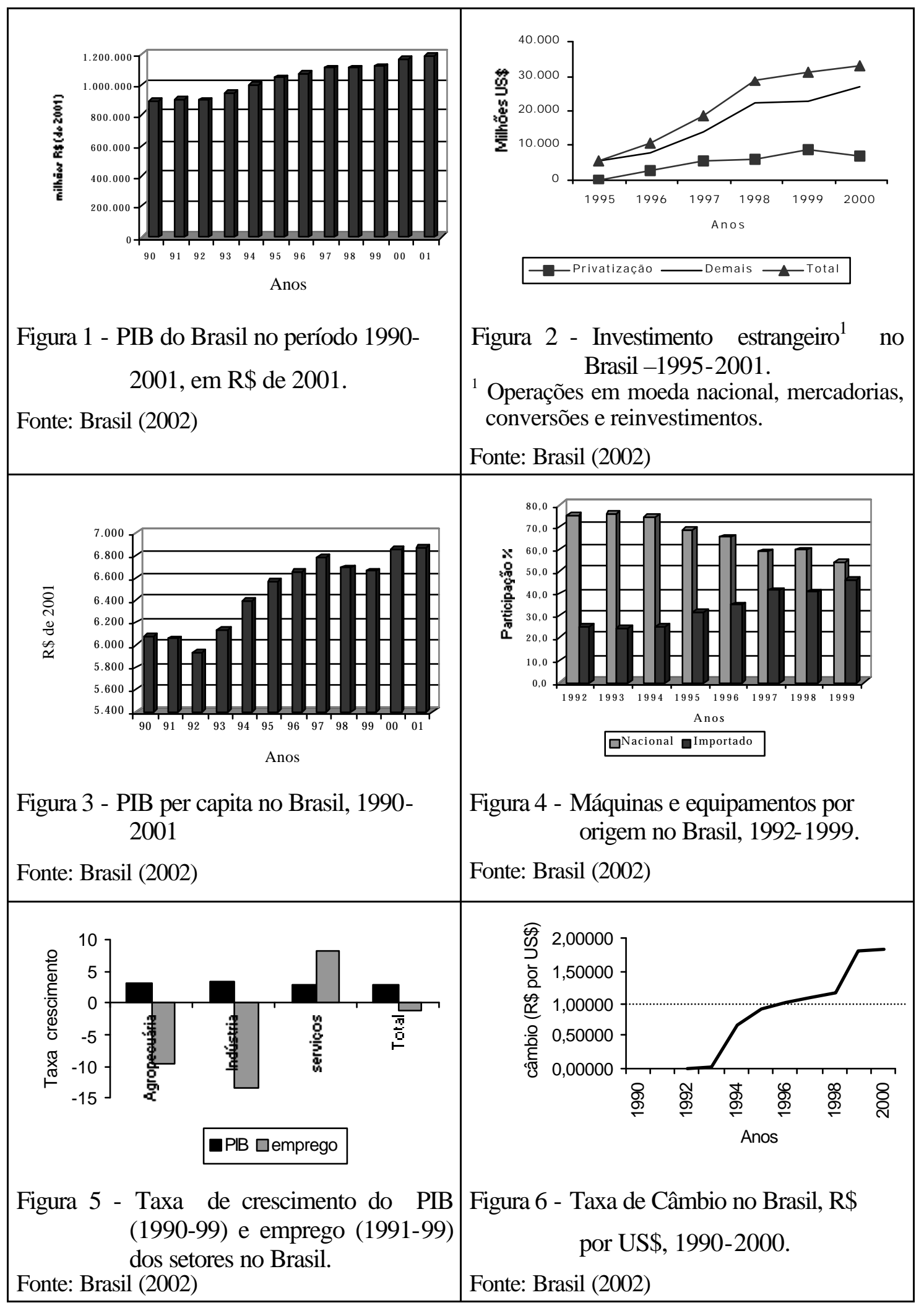


O comportamento do emprego no Brasil, entre 1991 e 1999, foi diferente do observado para o PIB. Entre esses anos, o volume total de empregos apresentou uma taxa de crescimento negativa, ou seja, houve uma redução no número total de postos de trabalho, quando se compara o número de pessoas ocupadas no ano de 1991 e no ano de $1999^{2}$. Na análise setorial, pode-se observar que os setores que tiveram os postos de trabalho reduzidos foram a agropecuária e a indústria. Apenas no setor de serviços, o volume total de empregos aumentou (Figura 5).

A análise em relação à utilização da mão-de-obra demonstra uma maior descontração nos setores ligados à indústria e à agricultura. Através dos dados da Tabela 1, constata-se que a maior parcela do pessoal ocupado, no Brasil, se encontrava empregada no setor de serviços. A agropecuária foi o segundo setor a empregar: em média, 24\% do pessoal ocupado, nos anos 90, estava de alguma forma ligado às atividades desse setor. Com relação à agropecuária, cabe destacar que sua importância na geração de empregos, no Brasil, foi maior que sua participação no PIB. Na indústria, o inverso pode ser observado na Tabela 1 , ou seja, foi o segundo setor na geração do PIB e o terceiro na ocupação da mão-de-obra. Com isso, espera-se uma maior produtividade nesse setor agregado, se comparado à agropecuária nos anos 90. Cabe destacar que essa colocação não é válida para todas as atividades igualmente, ou seja, pode-se observar casos isolados com comportamento diferenciado do acima exposto.

Uma análise desagregada das atividades que fazem parte da indústria e dos serviços pode ser feita com base na Tabela 1 . Na indústria, pode-se verificar que quase todas as atividades tiveram sua participação no PIB aumentada, comparando as informações de 1991 e de 1999, com exceção da indústria de transformação. Com relação ao emprego, apenas a construção civil teve sua participação incrementada. A análise das atividades ligadas ao setor de serviços mostra que a participação no PIB do comércio e do transporte se reduziu enquanto no emprego aumentou. A participação da administração pública no PIB foi reduzida, juntamente com sua importância em relação

\footnotetext{
${ }^{2}$ Esse resultado não permite afirmar que o volume de empregos tenha decrescido continuamente no período, mas apenas demonstra que o número de pessoas ocupadas em 1999 foi menor que o número de pessoas ocupadas em 1991.
} 
ao pessoal ocupado. Acredita-se que tal comportamento se deva, basicamente, a dois fatores: a privatização e o déficit orçamentário do governo.

Tabela 1. Participação percentual dos setores no produto interno bruto brasileiro e no emprego, 1990, 1996, 1999 e 2001.

\begin{tabular}{lrrrrrr}
\hline Setores & \multicolumn{3}{c}{ PIB } & \multicolumn{4}{c}{ Emprego } \\
& 1991 & 1996 & 1999 & 1991 & 1996 & 1999 \\
\cline { 2 - 7 } Agropecuária & 7,8 & 8,3 & 8,4 & 25,9 & 23,3 & 23,6 \\
Indústria & 36,2 & 34,7 & 35,4 & 21,9 & 20,0 & 19,2 \\
$\quad$ Extrativa mineral & 1,6 & 1,0 & 1,7 & 0,5 & 0,4 & 0,4 \\
Transformação & 24,9 & 21,5 & 21,3 & 14,6 & 13,4 & 12,1 \\
Construção civil & 7,1 & 9,5 & 9,5 & 6,2 & 5,9 & 6,3 \\
Serv. ind. util. publ. & 2,6 & 2,7 & 2,9 & 0,5 & 0,4 & 0,4 \\
Serviços & 56,0 & 57,0 & 56,2 & 52,2 & 56,7 & 57,2 \\
Comércio & 9,8 & 7,8 & 7,7 & 13,0 & 14,6 & 15,2 \\
Transportes & 3,8 & 3,0 & 3,4 & 3,5 & 3,8 & 4,0 \\
Comunicações & 1,2 & 1,9 & 2,0 & 0,3 & 0,3 & 0,3 \\
Administração Pública & 15,4 & 16,0 & 16,1 & 10,1 & 9,0 & 8,4 \\
$\quad$ Demais setores & 25,9 & 28,3 & 27,0 & 25,3 & 29,0 & 29,2 \\
Total das atividades & 100,0 & 100,0 & 100,0 & 100,0 & 100,0 & 100,0 \\
\hline
\end{tabular}

Fonte: Brasil (2002); Anuário Estatístico do Brasil (2002)

Com relação às atividades ligadas à comunicação, cabe ressaltar que sua importância no PIB do Brasil cresceu, ao passo que sua importância em relação ao volume de empregos se manteve constante (Tabela 1). Esse crescimento da importância da comunicação na produção, não acompanhada pelo aumento no volume de empregos, parece sugerir, também, um aumento na produtividade da mão-de-obra nessa atividade.

Nesta seção, pôde-se verificar as principais transformações pelas quais a economia brasileira passou nos anos 90, através de uma análise descritiva de seus principais agregados econômicos. Nesse período, constatou-se que a economia apresentou uma taxa de crescimento positiva, que o número de postos de trabalho foi reduzido, que os investimentos estrangeiros aumentaram e que houve a valorização da moeda local, o real, dentre outras mudanças. Na próxima seção, o objetivo é verificar as diferenças regionais para algumas variáveis gerais e outras especificas do mercado de 
trabalho. Este último será observado em maiores detalhes, por se tratar de uma variável utilizada no presente trabalho.

\subsection{Desigualdades regionais}

Uma análise regional do impacto das transformações na economia brasileira demonstrou que não houve mudança na importância relativa das grandes regiões e unidades da Federação. No período compreendido entre os anos de 1995 e 1999, conforme mostra a Tabela 2, 58\% do PIB brasileiro encontrava-se concentrado na região Sudeste, onde São Paulo foi o principal estado da região e do País, respondendo por aproximadamente 35\% do PIB nacional. O Rio de Janeiro, com aproximadamente 11\% do PIB, foi o segundo estado, seguido por Minas Gerais, com $10 \%$.

A segunda região em termos de importância no PIB foi a Sul que, no segundo qüinquiênio da década de 90, foi responsável por aproximadamente 18\% do PIB. Nesta região, os principais estados produtores foram: Rio Grande do Sul e Paraná. O Nordeste foi a terceira principal região a produzir: no Brasil, respondeu por aproximadamente 13\% do PIB nacional entre 1995 e 1999. A Bahia, principal estado produtor dessa região, foi responsável por aproximadamente $4 \%$ do PIB, seguida dos estados de Pernambuco e do Ceará (ver Tabela 2).

As regiões Norte e Centro-Oeste foram as que apresentam as menores participações na produção nacional, aproximadamente $4 \%$ e $6 \%$, respectivamente (Tabela 2). Cabe destacar que, apesar de apresentarem as menores participações em relação ao PIB nacional, as referidas regiões são importantes reservas de recursos naturais do País. A região Centro-Oeste também se destaca como importante na expansão da fronteira agropecuária do Brasil. As maiores participações no PIB do Centro-Oeste foram observadas no Distrito Federal e em Goiás. No Norte, os principais estados produtores foram o Amazonas e o Pará. 
Tabela 2. Participação percentual das grandes regiões e unidades da Federação no PIB brasileiro, 1995-1999.

\begin{tabular}{lrrrrr}
\hline Estados e regiões & 1995 & 1996 & 1997 & 1998 & 1999 \\
\hline Norte & 4,6 & 4,6 & 4,4 & 4,5 & 4,4 \\
Rondônia & 0,5 & 0,5 & 0,5 & 0,5 & 0,5 \\
Acre & 0,2 & 0,1 & 0,2 & 0,2 & 0,2 \\
Amazonas & 1,7 & 1,8 & 1,7 & 1,7 & 1,6 \\
Roraima & 0,1 & 0,1 & 0,1 & 0,1 & 0,1 \\
Pará & 1,9 & 1,8 & 1,7 & 1,7 & 1,7 \\
Amapá & 0,2 & 0,2 & 0,2 & 0,2 & 0,2 \\
Tocantins & 0,2 & 0,2 & 0,2 & 0,2 & 0,2 \\
Nordeste & 12,8 & 13,2 & 13,1 & 13,1 & 13,1 \\
Maranhão & 0,8 & 0,9 & 0,9 & 0,8 & 0,8 \\
Piaúi & 0,5 & 0,5 & 0,5 & 0,5 & 0,5 \\
Ceará & 1,9 & 2,0 & 2,0 & 2,1 & 2,0 \\
Rio Grande do Norte & 0,7 & 0,8 & 0,8 & 0,7 & 0,8 \\
Paraíba & 0,8 & 0,8 & 0,8 & 0,8 & 0,8 \\
Pernambuco & 2,7 & 2,7 & 2,7 & 2,7 & 2,7 \\
Alagoas & 0,6 & 0,7 & 0,7 & 0,7 & 0,7 \\
Sergipe & 0,5 & 0,6 & 0,6 & 0,6 & 0,6 \\
Bahia & 4,1 & 4,2 & 4,3 & 4,2 & 4,3 \\
Sudeste & 58,7 & 58,1 & 58,6 & 58,2 & 58,3 \\
Minas Gerais & 9,7 & 10,1 & 10,0 & 9,8 & 9,6 \\
Espírito Santo & 2,0 & 1,9 & 1,9 & 1,9 & 1,9 \\
Rio de Janeiro & 11,5 & 11,1 & 11,2 & 11,0 & 11,7 \\
São Paulo & 35,5 & 34,9 & 35,5 & 35,5 & 34,9 \\
Sul & 17,9 & 18,0 & 17,7 & 17,5 & 17,7 \\
Paraná & 5,9 & 6,1 & 6,1 & 6,2 & 6,3 \\
Santa Catarina & 3,6 & 3,8 & 3,7 & 3,5 & 3,7 \\
Rio de Grande do Sul & 8,3 & 8,1 & 7,9 & 7,7 & 7,7 \\
Centro-Oeste & 6,0 & 6,1 & 6,2 & 6,8 & 6,4 \\
Mato Grosso do Sul & 1,1 & 1,1 & 1,1 & 1,1 & 1,1 \\
Mato Grosso & 1,0 & 1,0 & 1,1 & 1,1 & 1,2 \\
Goiás & 1,8 & 1,9 & 1,8 & 1,9 & 1,8 \\
Distrito Federal & 2,0 & 2,1 & 2,3 & 2,7 & 2,3 \\
Brasil & 100,0 & 100,0 & 100,0 & 100,0 & 100,0 \\
\hline Font Brasion & & & & &
\end{tabular}

Fonte: Brasil (2002)

Uma análise mais detalhada da importância de cada uma das regiões nos principais setores produtores na economia brasileira pode ser realizada a partir dos dados da Tabela 3. Nesta, pode-se observar que o Sudeste se destacou como principal produtor, 
em quase todos os setores, com exceção dos segmentos ligados à madeira, mobiliário, celulose e pasta e àfabricação de calçados, para os quais o Sul foi o principal produtor.

Tabela 3. Participação percentual das regiões no valor adicionado em cada um dos setores no ano de 1999.

\begin{tabular}{|c|c|c|c|c|c|c|}
\hline Setores & Norte & Nordeste & $\begin{array}{l}\text { Centro- } \\
\text { Oeste }\end{array}$ & Sudeste & $\mathrm{Sul}$ & Brasil \\
\hline Agropecuária & 8,03 & 14,45 & 11,76 & 34,70 & 31,06 & 100,00 \\
\hline Extrativa mineral (exceto combustíveis) & 13,76 & 4,17 & 5,94 & 74,89 & 1,24 & 100,00 \\
\hline Extração de petróleo, gás, carvão e outros & 2,85 & 15,98 & 0,01 & 80,48 & 0,68 & 100,00 \\
\hline Minerais não metálicos & 4,16 & 7,94 & 4,47 & 65,80 & 17,63 & 100,00 \\
\hline Siderurgia e metalúrgicos ferrosos ou não & 2,33 & 10,43 & 1,06 & 74,02 & 12,15 & 100,00 \\
\hline Fab. e manutenção de máquinas e tratores & 2,26 & 2,19 & 0,75 & 66,34 & 28,46 & 100,00 \\
\hline Material elétrico e eletrônico & 14,92 & 2,21 & 0,41 & 69,81 & 12,65 & 100,00 \\
\hline Automóveis, outros veículos e peças & 6,35 & 0,58 & 0,13 & 75,87 & 17,08 & 100,00 \\
\hline Madeira mobiliário, celulose e pasta & 12,00 & 1,66 & 5,05 & 31,03 & 50,27 & 100,00 \\
\hline Indústria de papel e gráfica & 3,82 & 4,59 & 1,00 & 70,55 & 20,04 & 100,00 \\
\hline Indústria da borracha & 2,20 & 4,03 & 0,89 & 71,81 & 21,07 & 100,00 \\
\hline Químicos diversos & 5,99 & 10,83 & 4,27 & 65,45 & 13,46 & 100,00 \\
\hline Refino de petróleo & 0,03 & 30,01 & 0,38 & 52,12 & 17,46 & 100,00 \\
\hline Farmacêutica e veterinária & 4,02 & 1,59 & 0,61 & 92,61 & 1,17 & 100,00 \\
\hline Artigos de plástico & 5,91 & 3,24 & 0,21 & 67,35 & 23,30 & 100,00 \\
\hline Indústria têxtil & 1,62 & 13,39 & 0,92 & 62,96 & 21,11 & 100,00 \\
\hline Artigos vestuário & 0,34 & 7,15 & 2,18 & 60,32 & 30,01 & 100,00 \\
\hline Fabricação do calçados & 0,22 & 14,48 & 1,46 & 24,83 & 59,01 & 100,00 \\
\hline Produtos alimentares & 5,16 & 11,22 & 6,24 & 50,02 & 27,36 & 100,00 \\
\hline Indústrias diversas & 4,74 & 1,33 & 2,11 & 47,59 & 44,23 & 100,00 \\
\hline SIUP & 3,61 & 11,33 & 4,20 & 63,72 & 17,15 & 100,00 \\
\hline Construção civil & 5,10 & 18,25 & 5,30 & 55,23 & 16,14 & 100,00 \\
\hline Comércio & 4,52 & 14,71 & 6,94 & 54,54 & 19,29 & 100,00 \\
\hline Transporte & 5,92 & 17,69 & 7,70 & 50,43 & 18,26 & 100,00 \\
\hline Comunicações & 1,89 & 13,18 & 7,34 & 65,06 & 12,53 & 100,00 \\
\hline Instituições financeiras & 1,61 & 7,03 & 15,47 & 63,78 & 12,11 & 100,00 \\
\hline Serviços prestados às famílias & 4,92 & 14,90 & 7,70 & 56,03 & 16,45 & 100,00 \\
\hline Serviços prestados às empresas & 3,83 & 9,76 & 3,77 & 71,41 & 11,24 & 100,00 \\
\hline Aluguel imóveis & 2,57 & 10,07 & 4,45 & 65,82 & 17,09 & 100,00 \\
\hline Administração Pública & 6,13 & 15,63 & 21,46 & 44,49 & 12,29 & 100,00 \\
\hline Serv. Privados não mercantis & 3,16 & 12,75 & 8,25 & 58,73 & 17,12 & 100,00 \\
\hline Total & 4,56 & 12,87 & 8,69 & 56,42 & 17,46 & 100,00 \\
\hline
\end{tabular}

Fonte: Elaborada a partir dos dados obtidos por Guilhoto et al. ${ }^{3}$ (2003)

3 GUILHOTO, J.J.M.; LOPES, R.L.; SESSO FILHO, U.A. et al. Matriz insumo-produto e interregional para a economia brasileira para 1999. Piracicaba: ESALQ Depto. Economia, Administração e Sociologia. (Texto para discussão) 
A região Sul foi a segunda principal produtora, no Brasil, da quase totalidade dos setores; as exceções foram: a extrativa mineral (Norte); a extração de petróleo, gás, carvão e outros ( Nordeste ); o material elétrico e eletrônico ( Norte ); o refino de petróleo (Nordeste); a farmacêutica e veterinária (Norte); a construção civil e comunicações (Nordeste) e a administração pública (Centro-Oeste). Os resultados das Tabelas 2 e 3 demonstram a alta concentração da produção brasileira na região Sudeste, principalmente no estado de São Paulo e no Sul. As demais regiões se destacaram em alguns setores específicos, mas não como principais produtoras.

A grande importância da região Sudeste, para o Brasil, não se restringe apenas à localização da produção, mas também na concentração da população. Conforme mostra a Figura 7, mais de $40 \%$ da população brasileira tinha, em 1999, sua residência fixada nessa região. O Nordeste foi a segunda principal região em termos de população, seguido do Sul, do Norte e do Centro-Oeste.

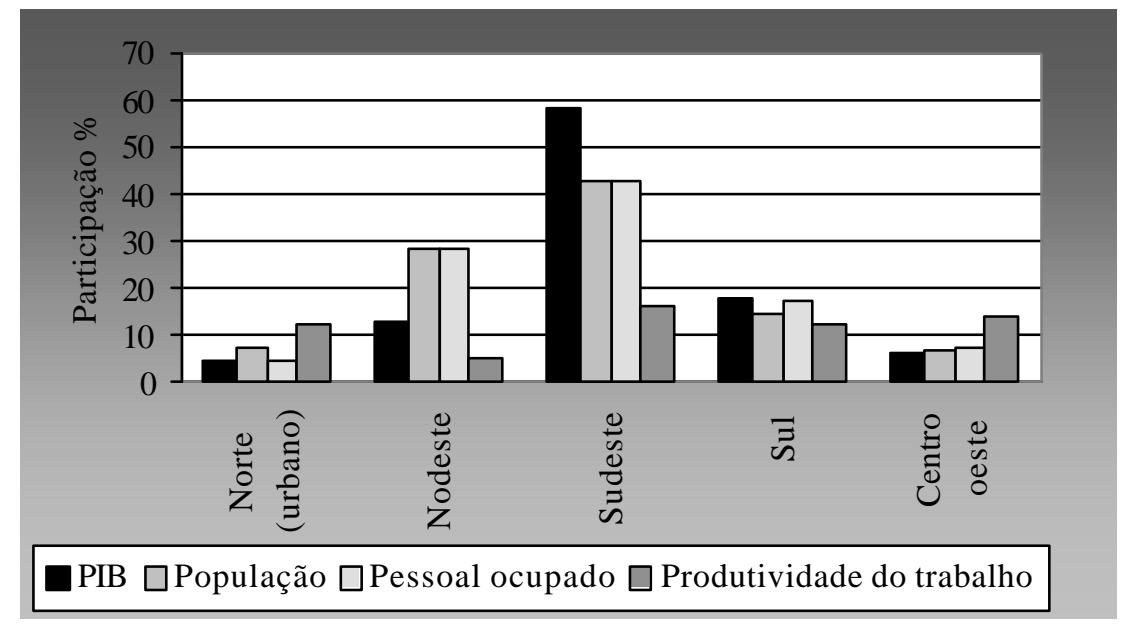

Figura 7 - Participação percentual das regiões brasileiras em relação ao PIB, à população e ao pessoal ocupado, em 1999.

Fonte: Brasil (2002); IBGE (1999a) 
Na Figura 7, pode-se verificar também a distribuição do mercado de trabalho, no Brasil. Observou-se uma grande concentração do pessoal ocupado no Sudeste, em 1999, com mais de 40\%, seguido do Nordeste, do Sul do Centro-Oeste e do Norte.

A maior parcela da população e do pessoal ocupado encontravam-se nas regiões Sudeste, Nordeste e Sul, em 1999. Essas também foram as principais regiões, como se pode verificar na Figura 7, na participação no PIB. O que se observa, também na Figura 7, são divergências em relação às regiões, quando se comparam suas participações no PIB e no mercado de trabalho. No Sudeste sua participação em relação ao PIB foi maior, em relação a sua participação no mercado de trabalho. $O$ inverso se observa no Nordeste, onde a importância da região, em relação ao PIB, foi bem menor, se comparada ao pessoal ocupado. O Sul, apesar de ter sido a segunda região de maior importância em relação ao PIB, foi a terceira no que diz respeito ao mercado de trabalho. No Centro-Oeste, assim como no Nordeste, a importância da região no mercado de trabalho é um pouco menor, se comparada ao PIB.

As maiores diferenças puderam ser observadas entre as regiões Sudeste e Nordeste. Esta última, apesar de ter uma menor representatividade no PIB, apresentou-se como uma região importante na utilização da mão-de-obra, o que levou a mesma a apresentar uma produtividade do trabalho bem menor, se comparada à do Sudeste e à das demais regiões, como se pode verificar na Figura 7.

Quanto aos setores responsáveis pela ocupação da mão-de-obra, pode-se verificar na Figura 8 a importância dos segmentos ligados aos agregados da agropecuária, da indústria e dos serviços, em cada uma das regiões. As atividades ligadas à prestação de serviços foram as principais a empregar mão-de-obra em todas as regiões. Isto demonstra a importância desse segmento para o mercado de trabalho formal e informal ${ }^{4}$ no País.

A agropecuária destacou-se como o segundo principal agregado na ocupação da mão-de-obra no Brasil como um todo e nas regiões Centro-Oeste, Sul e Nordeste. Com

\footnotetext{
${ }^{4}$ Os dados levantados pela PNAD abrangem esses dois segmentos do mercado de trabalho, sendo que, no caso da região Norte, a pesquisa se restringe àzona urbana.
} 
relação a esta última região, verifica-se na Figura 8 a grande importância que as atividades ligadas à agropecuária tiveram para o mercado de trabalho local. Este agregado sozinho respondeu por aproximadamente $40 \%$ do pessoal ocupado, no Nordeste. Para o Sudeste e o Norte, a indústria apresentou-se como o segundo maior segmento para o emprego, depois dos serviços. Com relação ao Norte, cabe lembrar que o levantamento da PNAD se restringe à zona urbana. Essa pode ser a explicação para a grande importância da indústria na região.

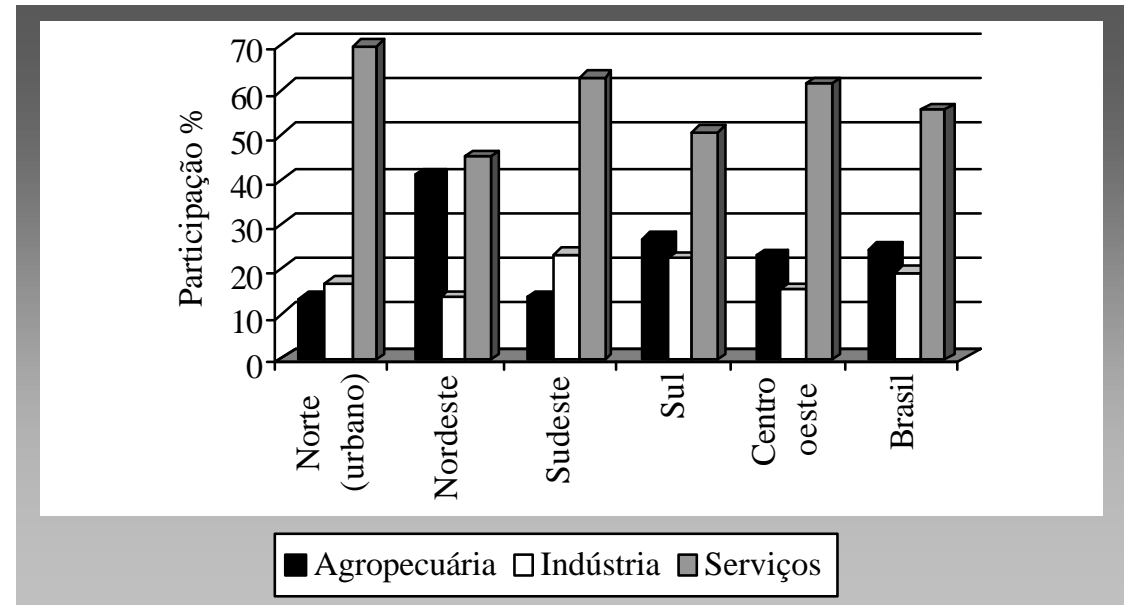

Figura 8 - Participação percentual das atividades ligadas à agropecuária, à indústria e aos serviços em relação ao pessoal ocupado, nas regiões do Brasil, em 1999.

Fonte: IBGE (1999a)

Os dados da Tabela 4 mostram a importância dos diversos níveis de escolaridade da mão-de-obra, nas macrorregiões e no Brasil. No Nordeste, observoutse uma maior concentração de pessoas ocupadas sem instrução e com menos de um ano de estudo 26,28\%. Considerando o total de pessoas ocupadas na região com no máximo sete anos de estudo, essas responderam por $74,45 \%$ do total da mão-de-obra local. Para as demais regiões, os trabalhadores apresentaram, em geral, um nível de escolaridade mais 
elevado, ou seja, a maior parte do pessoal ocupado tinha entre quatro e sete anos de estudo e entre onze e quatorze anos de estudo, juntos eles representaram aproximadamente $49 \%$ do total de pessoas ocupadas.

Tabela 4. Participação percentual dos diversos níveis de escolaridade do pessoal ocupado nas regiões do Brasil, em 1999.

\begin{tabular}{lrrrrrr}
\hline Escolaridade & Norte & Nordeste & Sudeste & Sul & $\begin{array}{r}\text { Centro- } \\
\text { Oeste }\end{array}$ & Brasil \\
\hline Sem instrução e menos & & & & & & \\
De 1 ano de estudo & 13,34 & 26,28 & 6,85 & 6,24 & 9,76 & 12,83 \\
1-3 anos de estudo & 17,34 & 23,52 & 12,24 & 12,43 & 15,82 & 16,00 \\
4-7 anos de estudo & 28,21 & 24,65 & 32,00 & 38,81 & 33,57 & 30,98 \\
8-10 anos de estudo & 16,05 & 9,20 & 18,11 & 17,46 & 16,12 & 15,21 \\
11-14 anos de estudo & 20,56 & 13,00 & 21,70 & 18,18 & 18,19 & 18,30 \\
15 anos ou mais de estudo & 4,49 & 3,34 & 9,10 & 6,88 & 6,54 & 6,68 \\
Total & 100,00 & 100,00 & 100,00 & 100,00 & 100,00 & 100,00 \\
\hline
\end{tabular}

Fonte: IBGE (1999a)

Com o objetivo de avaliar a distribuição de renda do pessoal ocupado nas regiões, foi elaborada a Tabela 5. Nesta pode-se verificar a participação de cada uma das regiões nas diversas categorias de rendimento, para o pessoal ocupado. O Nordeste foi a região que concentrou o maior volume de pessoas ocupadas com os menores rendimentos. Considerando os trabalhadores no Brasil que recebiam, em 1999, até meio salário mínimo, $61,72 \%$ destes encontravam-se no Nordeste e $44,17 \%$ do pessoal ocupado que tinha um rendimento entre meio a 1 salário mínimo também encontrava-se na referida região. A maior parcela das pessoas ocupadas, no Brasil, sem rendimentos concentrou-se na região Nordeste - 47,85\%. Assim, a região se apresentou como a principal somente nos segmentos mais baixos de rendimento, no País. Os dados da Tabela 5 demonstram que houve uma maior concentração de trabalhadores nos demais estratos de rendimento nas regiões Sudeste e Sul do Brasil. 
Tabela 5. Participação percentual das regiões do Brasil em relação aos estratos de rendimento das pessoas ocupadas no ano de 1999.

\begin{tabular}{lrrrrrr}
\hline Rendimento & Norte & Nordeste & Sudeste & Sul & Oeste & Brasil \\
\hline Até 1/salário mínimo & 4,34 & 61,72 & 18,60 & 10,24 & 5,11 & 100,00 \\
De 1/2 a 1 salário mínimo & 5,56 & 44,17 & 30,71 & 12,08 & 7,48 & 100,00 \\
De 1 a 2 salários mínimos & 5,22 & 27,19 & 41,82 & 17,16 & 8,60 & 100,00 \\
De 2 a 3 salários mínimos & 4,12 & 16,03 & 54,10 & 18,07 & 7,68 & 100,00 \\
De 3 a 5 salários mínimos & 4,28 & 13,18 & 56,76 & 18,73 & 7,06 & 100,00 \\
De 5 a 10 salários mínimos & 4,02 & 11,38 & 59,15 & 18,37 & 7,08 & 100,00 \\
De 10 a 20 salários & & & & & & \\
mínimos & 3,68 & 11,60 & 59,43 & 17,59 & 7,69 & 100,00 \\
Mais de 20 salários & & & & & & \\
mínimos & 3,02 & 12,36 & 57,84 & 17,80 & 8,97 & 100,00 \\
Sem rendimento & 3,21 & 47,85 & 22,33 & 20,99 & 5,61 & 100,00 \\
\hline
\end{tabular}

Fonte: IBGE (1999a)

Os dados analisados nesta seção demonstraram a grande concentração da produção, da população e do pessoal ocupado mais qualificado e com maiores rendimentos na região Sudeste. Puderam ser verificadas também as divergências de análise em relação a esta região e ao Nordeste, pois, no Nordeste, observou-se uma grande concentração de trabalho não-qualificado com baixa produtividade do trabalho e as menores remunerações. Com relação à produção, o Sul destacou-se como a segunda principal região a produzir no País, seguida pelo Nordeste. No que se refere ao mercado de trabalho; às regiões Sudeste e Nordeste apresentaram-se como as principais a empregar mão-de-obra, no Brasil. Depois de descritas algumas diferenças regionais, na presente seção, nas seções seguintes serão observados os comportamentos do comércio interno e externo. Cabe destacar que esses dois tipos de comércio são também importantes objetos de análise neste trabalho; por isso foram observados com mais detalhes. 


\subsection{Comércio exterior}

Nos últimos anos, têm-se observado mudanças muito importantes no comércio internacional. A liberalização comercial e o processo de formação de blocos regionais de comércio são alguns exemplos dessas mudanças. Nos anos 90, o Brasil contou ainda com a valorização da moeda local, o real, frente ao dólar, o que, juntamente com o processo de abertura econômica, explica o aumento de 170\% das importações (Brasil, 2000), principalmente no início do Plano Real, em 1994, de acordo com a Figura 9.

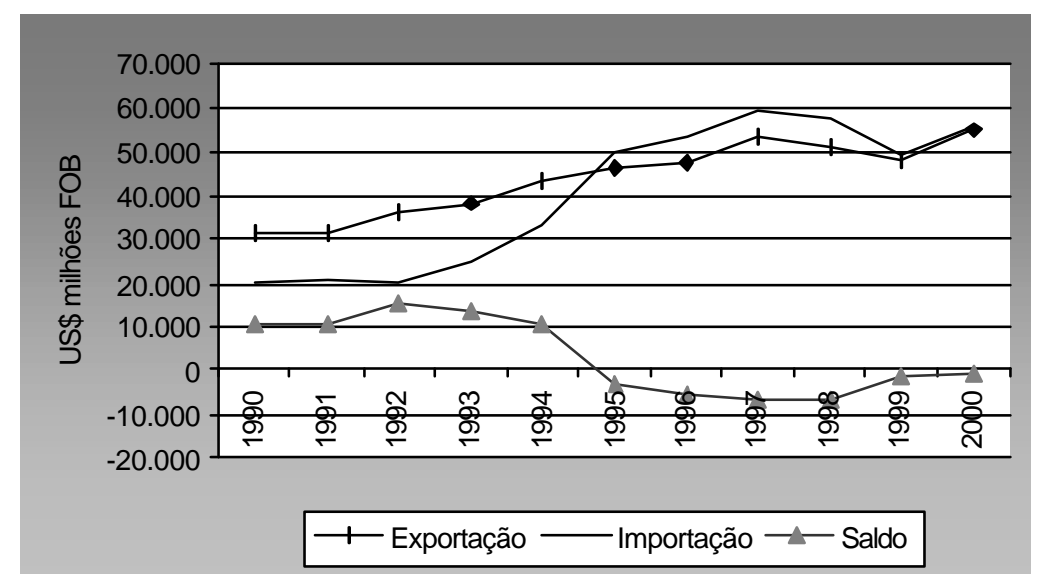

Figura 9 - Exportação, importação e saldo da balança comercial do Brasil, em milhões de dólares FOB, 1990-2000.

Fonte: Brasil (2000)

Na década de 90, as exportações brasileiras aumentaram continuamente, como se pode observar Figura 9. Em 1990, o volume total das exportações era aproximadamente US\$ 30 bilhões, chegando, em 2000, a US\$ 55 bilhões. Apenas nos anos de 1998 e 1999, as exportações decresceram, o que, em parte, acredita-se estar relacionado à crise financeira no mercado internacional. Mesmo o bom desempenho das exportações não foi suficiente para acompanhar o incremento das importações - estas ultrapassaram o volume total das exportações no ano de 1995, o que resultou em um saldo negativo na balança comercial, ao longo do período 1995-2000 (Figura 9). 
A Tabela 6 mostra o comportamento dos fatores agregados, presentes nas exportações e nas importações brasileiras, ms anos compreendidos entre 1994 e 2000. Pode-se verificar que a maior parcela das exportações foi de produtos industrializados, dentre os quais se destacaram os manufaturados: estes, em 2000, foram responsáveis por $59 \%$ das exportações. Os produtos com maior participação nas exportações, dos manufaturados, foram os seguintes: aviões, automóveis de passageiros, aparelhos transmissores ou receptores e componentes e calçados e suas partes componentes (Brasil, 2000). Em 2000, de acordo com os dados da Tabela 6, os produtos semifaturados foram responsáveis por $15,4 \%$ do total das exportações brasileiras, com destaque para a pasta química de madeira, os produtos semimanufaturados de ferro e o aço e alumínio em bruto.

Os produtos classificados como básicos tiveram sua participação reduzida entre 1994 e 2000, passando de 25,4\% para 22,8\%. Os principais produtos básicos, presentes na pauta de exportação do Brasil em 2000, foram: minério de ferro e seus concentrados, soja, mesmo triturada, farelo e resíduos da extração do óleo de soja e café cru em grãos (Brasil, 2000).

A taxa de crescimento das exportações, no período 1991-2000, foi de 25,5\%, de acordo com os dados da Tabela 6. A análise desagregada da evolução da exportação demonstra que os produtos industrializados apresentaram uma taxa de crescimento, mais elevada, se comparada à dos produtos básicos, $28,8 \%$ e 13,6\%, respectivamente. Os produtos manufaturados foram os que apresentaram a maior taxa de crescimento, depois das operações especiais. Cabe ressaltar que estas últimas representaram apenas 2,7\% das exportações no ano de 2000, ao passo que os produtos manufaturados foram responsáveis por 59\% das exportações em 2000, de acordo com os dados da Tabela 6.

O grande crescimento das importações (68,8\%), no período 1994-2000, deve-se basicamente à abertura da economia e à valorização do real. $\mathrm{O}$ principal responsável por esse considerável desempenho nas importações foi o agregado matérias-primas e bens intermediários, o qual apresentou uma taxa de crescimento de 109\% (ver Tabela 6). Os principais produtos que se encontravam nesse agregado no ano de 2000 foram: produtos 
químicos e farmacêuticos; produtos intermediários (partes e peças) e produtos minerais, de acordo com Brasil (2000). No ano de 2000, esse agregado respondeu por 51\% do total das importações realizadas pelo Brasil. O segundo item que apresentou a maior taxa de crescimento, entre os importados, foram combustíveis e lubrificantes. Em 2000, este item foi responsável por 13,2\% das importações realizadas pelo Basil. O segundo principal agregado presente na pauta de importados do Brasil, foram os bens de capital, 24,4\%, que apresentaram um crescimento de 39\% entre 1994-2000. Os principais produtos que se encontravam na pauta de importação do Brasil para esse agregado, no ano de 2000 foram os seguintes: maquinaria industrial, máquinas e aparelhos para escritório e cientifico e parte e peças para bens de capital para a indústria (Brasil, 2000).

Tabela 6. Taxa de crescimento e participação percentual dos fatores agregados na exportação e importação do Brasil, 1994-2000.

\begin{tabular}{lllr}
\hline Discriminação & \multicolumn{2}{c}{$\begin{array}{r}\text { Paxticipação \% } \\
\text { crescimento }\end{array}$} \\
& 1994 & 2000 & $1994-2000$ \\
\hline EXPORTAÇÃO (por fator agregado) & 100,0 & 100,0 & 26,5 \\
Básicos & 25,4 & 22,8 & 13,6 \\
Produtos industrializados & 73,1 & 74,5 & 28,8 \\
$\quad$ Semimanufaturados & 15,8 & 15,4 & 23,3 \\
$\quad$ Manufaturados & 57,3 & 59,0 & 30,3 \\
Operações especiais ${ }^{1}$ & 1,5 & 2,7 & 135,9 \\
IMPORTAÇÃO (por categoria de uso) & 100,0 & 100,0 & 68,8 \\
Matérias primas e bens intermediários & 41,2 & 51,0 & 109,0 \\
Bens de consumo & 16,1 & 13,2 & 38,9 \\
Combustíveis e lubrificantes & 13,1 & 11,4 & 46,4 \\
Bens de capital & 29,6 & 24,4 & 39,0 \\
\hline
\end{tabular}

Fonte: Brasil (1994); Brasil (2000)

1 Neste agregado encontram-se os seguintes itens: reexportação, transações especiais, consumo de bordo e combustível para consumo de bordo.

A análise da origem e do destino dos produtos comercializados pelo Brasil no mercado mundial foi realizada neste trabalho considerando-se os principais parceiros do 
Brasil nesse mercado. O comércio do Brasil fez-se mais intenso com o bloco da América do Norte (Nafta) e da Europa (União Européia). Juntos esses blocos foram responsáveis por $55 \%$ do destino das exportações brasileiras e por $58 \%$ da origem das importações no ano de 1999 (Brasil, 2003). Com relação ao Nafta, cabe destacar a gande importância dos Estados Unidos no comércio realizado com o Brasil. Tal país, sozinho, foi o destino de $87 \%$ das exportações realizadas pelo Brasil para o bloco econômico do norte e foi a origem de $88 \%$ das importações. Devido à grande importância deste país no comércio entre o Brasil e o Nafta, fez-se a opção, neste trabalho, de considerar apenas o comércio do Brasil com os Estados Unidos, e não com o bloco como um todo.

$\mathrm{Na}$ Tabela 7, pode-se verificar a participação percentual dos principais parceiros do Brasil no comércio internacional. A União Européia foi o principal bloco com quem o Brasil realizou suas transações comerciais $(28,61 \%$ das exportações e $30,52 \%$ das importações), seguida dos Estados Unidos (22,60\% das exportações e $24,10 \%$ das importações), do Mercosul (14,12\% das exportações e 13,63 das importações) e da Ásia (11,94\% das exportações e 13,13 das importações). Juntos, eles respondem por $77,26 \%$ das exportações e por $81,39 \%$ das importações do Brasil. Os demais países com quem o Brasil comercializou encontram-se agregados no item resto do mundo e foram o destino de $22,74 \%$ das exportações brasileiras e a origem de $18,71 \%$ do total das importações realizadas pelo Brasil.

Tabela 7. Participação percentual dos blocos econômicos, dos Estados Unidos e do resto do mundo nas exportações e importações do Brasil, em 1999.

\begin{tabular}{lcc}
\hline Blocos e países & Exportação & Importação \\
\hline Blocos/Estados Unidos & 77,26 & 81,39 \\
Mercosul & 14,12 & 13,63 \\
Estados Unidos (inclusive Porto Rico) & 22,60 & 24,10 \\
União Européia & 28,61 & 30,52 \\
Ásia (exclusive Oriente Médio) & 11,94 & 13,13 \\
Resto do mundo & 22,74 & 18,61 \\
Total & 100,00 & 100,00 \\
\hline
\end{tabular}

Fonte: Elaborada com base nos dados obtidos em Brasil (2003) 
A análise regional do comércio estabelecido entre o Brasil e os principais blocos econômicos o resto do mundo e os Estados Unidos pode ser realizada, utilizandose, como base, a Figura 10 e a Tabela 8.

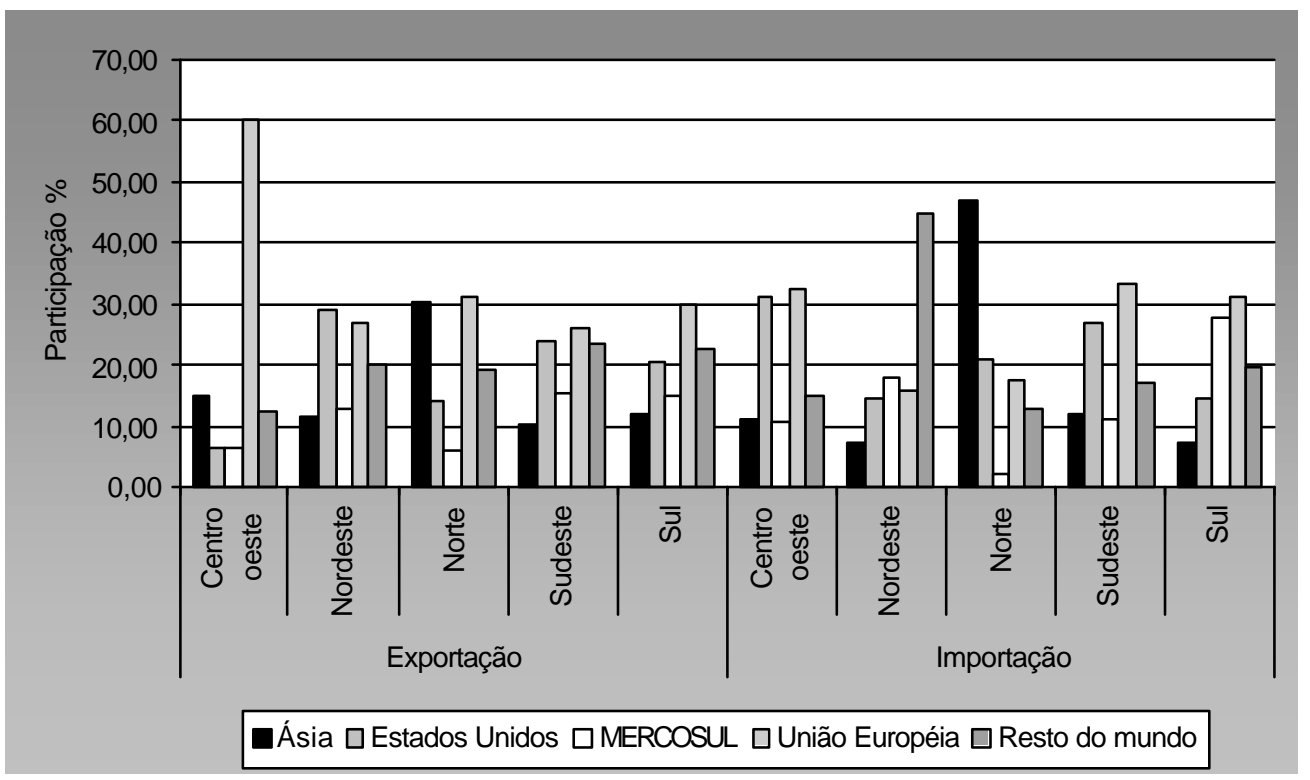

Figura 10 - Participação percentual dos parceiros comerciais nas exportações e importações das regiões em 1999.

Fonte: Elaborada com base nos dados obtidos em Brasil (2003)

A participação dos principais parceiros comerciais, nas exportações e importações das regiões no mercado mundial, pode ser observada na Figura 10. Pode-se verificar a importância da União Européia e da Ásia como destino das exportações do Centro-Oeste. A União Européia e os Estados Unidos foram importantes para a região, com relação à origem de suas importações. Ambos se destacaram, também, nas exportações realizadas pelo Nordeste. Com relação à origem das importações no Nordeste, verifica-se a grande importância do resto do mundo seguido do Mercosul, da União Européia e dos Estados Unidos. Na região Norte, a Ásia mostrou-se como sua 
principal parceira no mercado mundial ${ }^{5}$, juntamente com a União Européia. No Sudeste, destacaram-se os Estados Unidos e a União Européia no comércio com o exterior. Com relação à região Sul, cabe observar o Mercosul como uma das principais fontes de suas importações, juntamente com a União Européia e os Estados Unidos. Nessa região, as exportações tiveram como destinos principais a União Européia, os Estados Unidos e o Mercosul, conforme se pode verificar na Figura 10.

A importância das regiões brasileiras no comércio internacional pode ser observada na Tabela 8. A região Sudeste destacou-se como responsável por 59,81\% do total das exportações realizadas pelo Brasil, em 1999; foi, também, a mais importante nas importações, 67,98\%. A grande importância da região observoutse, também, quando se verifica o comércio na Tabela 8 , em relação aos principais parceiros comerciais no mercado internacional.

Tabela 8. Participação percentual das grandes regiões do Brasil nas exportações e importações no comércio internacional em 1999.

\begin{tabular}{lrrrrrr}
\hline Regiões & Ásia & $\begin{array}{r}\text { Estados } \\
\text { Unidos }\end{array}$ & Mercosul & $\begin{array}{r}\text { União } \\
\text { Européia }\end{array}$ & $\begin{array}{r}\text { Resto do } \\
\text { mundo }\end{array}$ & Total \\
\hline $\begin{array}{l}\text { Exportação } \\
\quad \text { Centro- }\end{array}$ & 100,00 & 100,00 & 100,00 & 100,00 & 100,00 & 100,00 \\
Oeste & 3,35 & 0,78 & 1,18 & 5,88 & 1,50 & 2,76 \\
$\quad$ Nordeste & 6,78 & 9,21 & 6,42 & 6,82 & 6,24 & 7,16 \\
$\quad$ Norte & 14,16 & 3,58 & 2,30 & 6,23 & 4,82 & 5,72 \\
$\quad$ Sudeste & 51,20 & 64,08 & 64,73 & 55,24 & 62,82 & 59,81 \\
$\quad$ Sul & 24,52 & 22,36 & 25,37 & 25,84 & 24,61 & 24,55 \\
Importação & 100,00 & 100,00 & 100,00 & 100,00 & 100,00 & 100,00 \\
$\quad$ Centro- & & & & & & \\
Oeste & 2,06 & 3,20 & 1,94 & 2,58 & 1,89 & 2,44 \\
$\quad$ Nordeste & 3,79 & 4,37 & 9,49 & 3,77 & 16,91 & 7,20 \\
$\quad$ Norte & 22,54 & 5,66 & 0,93 & 3,60 & 4,24 & 6,33 \\
$\quad$ Sudeste & 63,08 & 76,99 & 54,82 & 73,57 & 60,61 & 67,98 \\
$\quad$ Sul & 8,53 & 9,79 & 32,82 & 16,49 & 16,35 & 16,06 \\
\hline
\end{tabular}

Fonte: Elaborada com base nos dados obtidos em Brasil (2003)

\footnotetext{
${ }^{5}$ Acredita-se que essa grande participação da Ásia nas importações do Norte encontra-se associada ao fato de a Zona Franca de Manaus estar localizada na região, onde se destacam as importações de materiais elétricos e eletrônicos.
} 
De acordo com os dados da Tabela 8 , a região Sul foi a segunda região mais importante para o comércio exterior brasileiro. Ela respondeu pr $24,55 \%$ do total das exportações brasileiras, em 1999, e por 16,06\% do total das importações realizadas pelo país. Com relação às importações operadas pela região Sul, vale ressaltar que sua maior participação se encontra centrada nas importações que o Brasil realizou com origem no Mercosul, 32,82\%. A região Nordeste foi a terceira principal região no comércio internacional, seguida do Norte e do Centro-Oeste.

A importância relativa das atividades na exportação e na importação do Brasil, por bloco econômico, pode ser verificada na Tabela 9. Nas exportações realizadas para a Ásia, merecem destaque os seguintes setores: produtos alimentares $(31,14 \%)$, siderurgia e metalúrgicos, ferrosos ou não, $(20,28 \%)$ e extrativa mineral $(18,71 \%)$. Com relação às exportações para os Estados Unidos, cabe destacar a importância da siderurgia e dos metalúrgicos, ferrosos ou não, (17,15\%); dos automóveis, outros veículos e peças $(15,50 \%)$ e dos produtos alimentares $(12,85 \%)$. Considerando o volume total de exportações realizadas para o Mercosul, verifica-se, de acordo com os dados da Tabela 9, que os setores de maior importância foram: automóveis, outros veículos e peças (19,20\%); fabricação e manutenção de máquinas e tratores (11,57\%); siderurgia e metalúrgicos, ferrosos ou não, $(9,10 \%)$ e produtos alimentares $(9,02 \%)$. Nas exportações para a União Européia destacaram-se: produtos alimentares (34,52\%); agropecuária (9,65\%); siderurgia e metalúrgicos, ferrosos ou não, $(9,20 \%)$ e automóveis, outros veículos e peças $(8,47 \%)$. As exportações brasileiras para o resto do mundo, também, tiveram nos produtos alimentares, sua maior participação $(33,20 \%)$, seguidos dos automóveis, outros veículos e peças $(10,82 \%)$ e da siderurgia e dos metalúrgicos, ferrosos ou não, $(8,73 \%)$. 
Tabela 9. Participação percentual das atividades na exportação e importação do Brasil para a Ásia, os Estados Unidos, o Mercosul, a União Européia e o resto do mundo, no ano de 1999.

\begin{tabular}{|c|c|c|c|c|c|c|c|c|c|c|}
\hline \multirow{3}{*}{ Setores } & \multicolumn{5}{|c|}{ Exportação } & \multicolumn{5}{|c|}{ Importação } \\
\hline & & Estados & & União & Resto do & & Estados & & União & Resto do \\
\hline & Ásia & Unidos & Mercosul & Européia & mundo & Ásia & Unidos & Mercosul & Européia & mundo \\
\hline Agropecuária & 4,58 & 0,66 & 0,86 & 9,65 & 1,66 & 1,07 & 1,00 & 18,16 & 0,31 & 1,72 \\
\hline $\begin{array}{l}\text { Extrativa mineral (exceto } \\
\text { combustíveis) }\end{array}$ & 18,71 & 1,83 & 1,61 & 9,08 & 5,16 & 0,29 & 0,25 & 0,76 & 0,27 & 4,55 \\
\hline $\begin{array}{l}\text { Extração de petróleo, gás, } \\
\text { carvão e outros }\end{array}$ & 0,00 & 0,00 & 0,01 & 0,00 & 0,01 & 1,14 & 1,48 & 8,03 & 0,03 & 32,33 \\
\hline Minerais não metálicos & 0,63 & 1,87 & 2,31 & 1,32 & 1,75 & 0,77 & 0,72 & 0,22 & 1,21 & 0,45 \\
\hline $\begin{array}{l}\text { e metalúrgicos } \\
\text { não }\end{array}$ & 20,28 & 17,15 & 9,10 & 9,20 & 8,73 & 3,69 & 4,57 & 2,34 & 5,29 & 5,17 \\
\hline $\begin{array}{l}\text { Fab. e manutenção de } \\
\text { máquinas e tratores }\end{array}$ & 2,22 & 11,12 & 11,57 & 5,94 & 7,63 & 12,32 & 17,00 & 5,90 & 27,66 & 5,75 \\
\hline $\begin{array}{l}\text { Material elétrico e } \\
\text { eletrônico }\end{array}$ & 1,49 & 5,46 & 8,70 & 1,20 & 4,79 & 40,24 & 28,62 & 1,10 & 13,90 & 5,70 \\
\hline $\begin{array}{l}\text { Automóveis, outros } \\
\text { veículos e peças }\end{array}$ & 0,63 & 15,50 & 19,20 & 8,47 & 10,82 & 7,91 & 5,49 & 20,25 & 14,21 & 1,77 \\
\hline Madeira mobiliário & 1,46 & 5,49 & 2,19 & 4,88 & 1,69 & 0,29 & 0,35 & 0,52 & 0,63 & 0,13 \\
\hline Indústria de papel e gráfica & 7,89 & 4,23 & 5,78 & 4,84 & 3,49 & 0,78 & 2,83 & 1,91 & 2,20 & 2,59 \\
\hline Indústria da borracha & 0,38 & 2,45 & 2,49 & 0,81 & 1,62 & 3,68 & 1,45 & 1,20 & 1,29 & 0,39 \\
\hline Químicos diversos & 4,42 & 4,23 & 8,02 & 3,16 & 5,05 & 8,04 & 15,97 & 4,97 & 13,87 & 14,54 \\
\hline Refino de petróleo & 0,02 & 2,35 & 0,70 & 0,24 & 5,52 & 0,08 & 1,34 & 2,07 & 1,45 & 10,65 \\
\hline Farmacêutica e veterinária & 0,18 & 0,14 & 3,11 & 0,23 & 1,45 & 0,91 & 4,25 & 2,32 & 5,75 & 4,06 \\
\hline Artigos de plástico & 0,65 & 0,63 & 5,00 & 0,51 & 1,73 & 2,97 & 4,85 & 3,12 & 3,00 & 1,61 \\
\hline Indústria têxtil & 0,96 & 1,58 & 5,66 & 1,00 & 2,07 & 5,55 & 1,36 & 5,78 & 1,34 & 2,64 \\
\hline Artigos vestuário & 0,04 & 0,19 & 0,38 & 0,04 & 0,08 & 0,96 & 0,06 & 0,46 & 0,13 & 0,06 \\
\hline Fabricação do calçados & 3,36 & 9,55 & 2,07 & 3,87 & 1,46 & 0,90 & 0,04 & 1,73 & 0,12 & 0,12 \\
\hline Produtos alimentares & 31,14 & 12,85 & 9,02 & 34,52 & 33,20 & 1,03 & 1,10 & 18,39 & 3,05 & 4,34 \\
\hline Indústrias diversas & 0,97 & 2,72 & 2,19 & 1,03 & 2,07 & 7,38 & 7,25 & 0,76 & 4,28 & 1,44 \\
\hline SIUP & - & - & - & - & - & - & - & - & - & - \\
\hline Construção civil & 0,00 & 0,00 & 0,03 & 0,00 & 0,03 & 0,00 & 0,01 & 0,00 & 0,01 & 0,01 \\
\hline Comércio & - & - & - & - & - & - & - & - & - & - \\
\hline Transporte & - & - & - & - & - & - & - & - & - & - \\
\hline Comunicações & - & - & - & - & - & - & - & - & - & - \\
\hline $\begin{array}{l}\text { Instituições financeiras } \\
\text { Serviços prestados às }\end{array}$ & - & - & - & - & - & - & - & - & - & - \\
\hline famílias & - & - & - & - & - & - & - & - & - & - \\
\hline $\begin{array}{l}\text { Serviços prestados às } \\
\text { empresas }\end{array}$ & - & - & - & - & - & - & - & - & - & - \\
\hline Aluguel imóveis & - & - & - & - & - & - & - & - & - & - \\
\hline Administração Pública & - & - & - & - & - & - & - & - & - & - \\
\hline $\begin{array}{l}\text { mercantis } \\
\text { merios nao }\end{array}$ & - & - & - & - & - & - & - & - & - & - \\
\hline TOTAL & 100,00 & 100,00 & 100,00 & 100,00 & 100,00 & 100,00 & 100,00 & 100,00 & 100,00 & 100,00 \\
\hline
\end{tabular}

Fonte: Elaborada com base nos dados obtidos em Brasil (2003)

As importações realizadas pelo Brasil de seus principais parceiros comerciais podem ser observadas na Tabela 9. Nas importações com origem na Ásia, destacaram-se 
para os seguintes setores: material elétrico e eletrônico (40,24\%); fabricação e manutenção de máquinas e tratores $(12,32)$ e químicos diversos $(8,04 \%)$. Os principais setores nas importações realizadas dos Estados Unidos foram: material elétrico eletrônico (28,62\%); fabricação e manutenção de máquinas e tratores (17,00\%) e químicos diversos $(15,97 \%)$. As importações brasileiras com origem no Mercosul mostraram a importância dos automóveis, outros veículos e peças (20,25\%), dos produtos alimentares $(18,39 \%)$ e da agropecuária $(18,16 \%)$. Para a União Européia, as atividades que se destacaram foram: fabricação e manutenção de máquinas e tratores (27,66\%); automóveis, outros veículos e peças (14,21\%); material elétrico e eletrônico $(13,90 \%)$ e químicos diversos $(13,87 \%)$. As importações do resto do mundo foram mais concentradas nas atividades relacionadas à extração de petróleo, de gás, de carvão e de outros $(32,33 \%)$, químicos diversos $(14,54 \%)$ e refino de petróleo $(10,65 \%)$.

Os setores mais destacados nas exportações que o Brasil realizou para os destinos observados na Tabela 9 foram: produtos alimentares, siderurgia e metalúrgicos ferrosos ou não; automóveis, outros veículos e peças; extrativa mineral; agropecuária e fabricação e manutenção de máquinas e tratores. Com relação às importações, os setores que mais se destacaram foram: químicos diversos; material elétrico e eletrônico; fabricação e manutenção de máquinas e tratores; automóveis, outros veículos e peças; extração de petróleo, de gás, de carvão e de outros e refino de petróleo.

$\mathrm{Na}$ Figura 11 pode-se verificar o saldo das transações comerciais realizadas entre o Brasil e suas macrorregiões e o exterior. As únicas regiões superavitárias nesse tipo de comércio foram: a Sul e a Centro-Oeste. Cabe ainda observar que a região Sul foi a que apresentou o maior superávit. Com relação às regiões deficitárias, no comércio com o exterior, pode-se verificar na Figura 11 que o Sudeste foi a principal região a apresentar déficit para este tipo de comércio. 


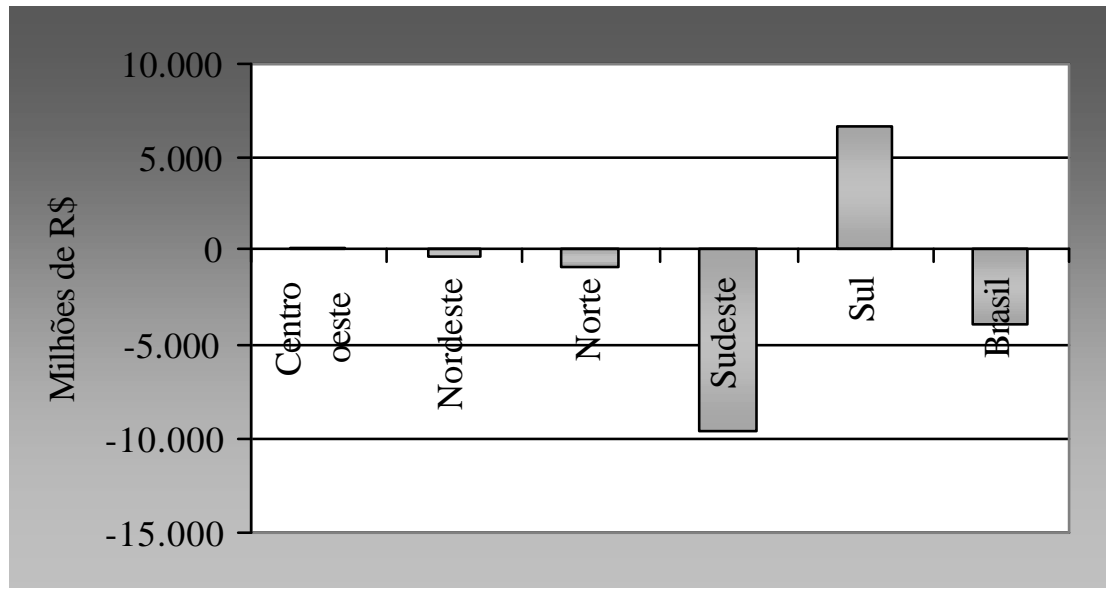

Figura 11 - Saldo (exportação - importação) do comércio realizado entre as regiões e o Brasil com o exterior no ano de 1999.

Fonte: Elaborada com base nos dados obtidos em Brasil (2003)

Nesta seção, o objetivo foi verificar o comportamento do comércio estabelecido entre o Brasil e as regiões e seus principais parceiros no mercado internacional: Ásia, Estados Unidos, Mercosul, União Européia e resto do mundo. Puderam ser observados os seguintes aspectos: o grande crescimento das importações, principalmente de matérias-primas e de bens intermediários; a importância da União Européia, dos Estados Unidos, do Mercosul e da Ásia no comércio internacional do Brasil e regiões; a grande participação da região Sudeste no comércio externo brasileiro; a participação das principais atividades na pauta de exportação e importação brasileira no ano de 1999 e o saldo das transações comerciais do Brasil e regiões no mercado externo. A seção seguinte tem como objetivo descrever o comércio estabelecido internamente entre as macrorregiões do Brasil, no ano de 1999.

\subsection{Comércio interno}

O comércio interno entre todas as regiões brasileiras somente se intensificou e se consolidou após os anos 50, com a efetivação do programa nacional de construção de rodovias. Antes desse período, o comércio existente com o exterior superava o comércio 
estabelecido entre as regiões. Em 1943, as exportações brasileiras para o resto do mundo superavam as exportações totais inter-regionais, por vias internas, em 2,7 vezes. Já no final dos anos sessenta tal processo foi invertido, já que o comércio inter-regional, por vias internas, passou a superar as exportações brasileiras em 1,6 vez, de acordo com Galvão (1999). Essa tendência crescente de comércio entre as regiões continuou a se consolidar nas décadas posteriores. Em 1998, o comércio inter-regional superou as exportações brasileiras em 7,3 vezes, de acordo com Brasil (2000) e Vasconcelos (2001).

A região, no Brasil, que respondeu pelo maior volume de exportação e importação no mercado doméstico foi a Sudeste, como se pode verificar na Figura 12. Há uma diferença considerável entre a participação do Sudeste e da região Sul, que foi a segunda região mais importante, no comércio estabelecido internamente. A terceira principal região foi a Nordeste, seguida do Norte e do Centro-Oeste.

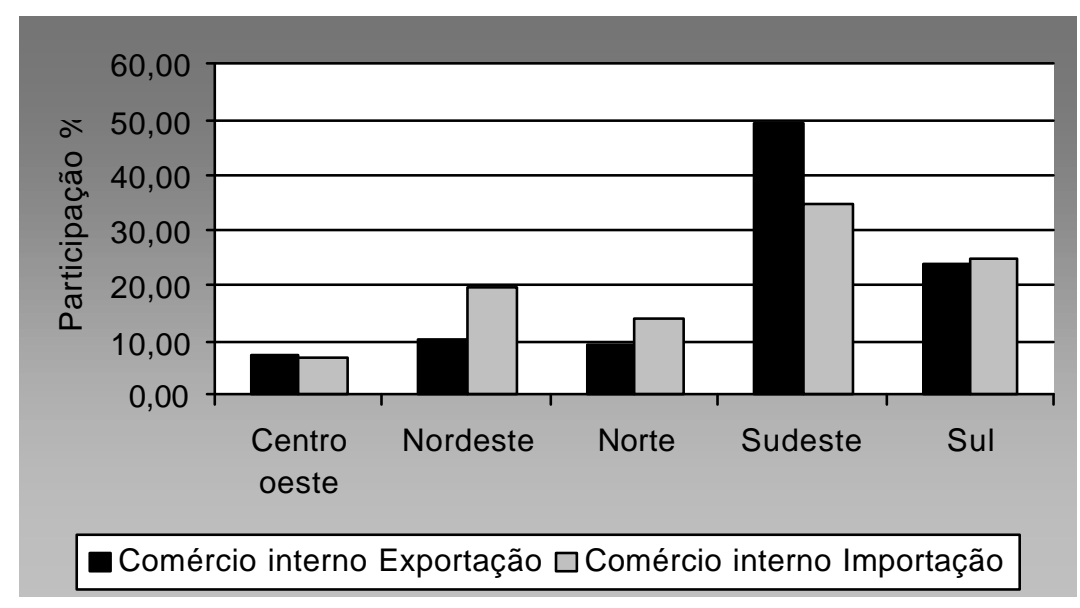

Figura 12 - Importação e exportação das macrorregiões brasileira no comércio interno, no ano de 1999.

Fonte: Elaborada a partir dos dados obtidos por Guilhoto et al., op. cit. (2003) 
A análise da estrutura do comércio realizado entre as regiões no mercado interno foi realizada com base nas Tabelas 10 e 11. Na Tabela 10, pode-se verificar a importância relativa das regiões de origem das importações realizadas em cada uma das macrorregiões. O Sudeste foi a principal região nas importações realizadas por todas as outras. Do total importado pelo Norte, 62,29\% tiveram como origem o Sudeste. Para o Nordeste, o Centro-Oeste e o Sul esses percentuais foram de 74,45\%, 73,33\% e 82,57\%, respectivamente. A segunda região mais importante foi a Sul. Ela também foi a principal fornecedora dos produtos importados pelo Sudeste, 48,00\%. Para as regiões Nordeste, Centro-Oeste e Norte o Sul foi a segunda fonte de importações, depois do Sudeste (ver Tabela 10).

Tabela 10. Participação percentual da origem das importações realizadas entre as regiões, no ano de 1999.

\begin{tabular}{lcrrrrr}
\hline Regiões & Norte & Nordeste & Centro-Oeste & Sudeste & Sul & Total \\
\hline Norte & - & 10,48 & 11,79 & 62,29 & 15,43 & 100,00 \\
Nordeste & 4,57 & - & 3,86 & 74,45 & 17,11 & 100,00 \\
Centro-Oeste & 3,67 & 4,46 & - & 73,33 & 18,54 & 100,00 \\
Sudeste & 14,42 & 21,22 & 16,36 & - & 48,00 & 100,00 \\
Sul & 3,09 & 5,73 & 8,60 & 82,57 & - & 100,00 \\
\hline
\end{tabular}

Fonte: Elaborada a partir dos dados obtidos por Guilhoto et al., op. cit. (2003)

O destino das exportações pode ser observado na Tabela 11. Nela pode-se verificar, também, a importância da região Sudeste como a principal importadora de bens e serviços das demais. Ela foi o destino de 69,94\% das exportações efetuadas pelo Norte, e de $72,94 \%$ das exportações realizadas pelo Nordeste. Do total das exportações realizadas pelo Centro-Oeste, $60,88 \%$ foram para o Sudeste; com relação às exportações do Sul para o Sudeste, o percentual foi de 70,53\%. O Nordeste foi o segundo maior destino para as exportações do Norte $(12,40 \%)$, do Sudeste $(20,84 \%)$ e do Sul $(14,06 \%)$. Já o Sul foi o principal destino das exportações do Sudeste (40,98\%) e o segundo principal destino das exportações do Nordeste $(13,81 \%)$ e do Centro-Oeste $(22,43 \%)$. 
Tabela 11. Participação percentual dos destinos das exportações realizadas entre as regiões, no ano de 1999.

\begin{tabular}{lcrrrrr}
\hline Regiões & Norte & Nordeste & Centro-Oeste & Sudeste & Sul & Total \\
\hline Norte & - & 12,40 & 7,15 & 69,94 & 10,51 & 100,00 \\
Nordeste & 7,10 & - & 6,16 & 72,94 & 13,81 & 100,00 \\
Centro-Oeste & 8,65 & 8,04 & - & 60,88 & 22,43 & 100,00 \\
Sudeste & 8,70 & 29,48 & 20,84 & - & 40,98 & 100,00 \\
Sul & 4,47 & 14,06 & 10,93 & 70,53 & - & 100,00 \\
\hline
\end{tabular}

Fonte: Elaborada a partir dos dados obtidos por Guilhoto et al., op. cit. (2003)

De acordo com os dados das Tabelas 10 e 11, as regiões Centro-Oeste e Norte não têm grande participação no comércio verificado internamente entre as regiões. Ambas também apresentam a menor participação no PIB do Brasil, como se pôde verificar na Tabela 2. O Sudeste, o Sul e o Nordeste são as regiões que apresentaram maior destaque no comércio e no PIB. Com isso, pode-se considerar uma maior concentração da produção e do comércio nessas três regiões com destaque, principalmente, para o Sudeste.

Os dados da Tabela 12 demonstram o saldo do comércio doméstico, por setor, em cada uma das regiões. As únicas regiões que apresentaram superávit, no comércio interno, foram a Sudeste e a Norte. A região Sudeste foi a que apresentou o maior superávit, quarenta e cinco vezes maior do que o verificado no Norte. As demais regiões apresentam déficit, estando mais acentuado na região Nordeste: duas vezes maior do que o verificado no Centro-Oeste, que apresenta o segundo maior déficit, e treze vezes maior que o do Sul.

No Norte, os setores que se destacaram como superavitários foram à agropecuária e os materiais elétricos e eletrônicos, este último em função da Zona Franca de Manaus, localizada na região. O setor que mais pesa na balança comercial do Norte com as demais regiões, como deficitário, é o refino de petróleo, seguido do aluguel de imóveis (Tabela 12). 
Tabela 12. Saldo (exportação-importação) do comércio realizado internamente entre as regiões, por setor no ano de 1999, valores em mil R\$.

\begin{tabular}{|c|c|c|c|c|c|}
\hline Setores & Norte & Nordeste & Centro-Oeste & Sudeste & Sul \\
\hline Agropecuária & 3.270 .179 & 2.221 .700 & 4.456 .745 & -15.973 .573 & 6.024 .949 \\
\hline Extrativa mineral (exceto combustíveis) & 425.234 & -273.669 & 135.515 & 125.325 & -412.404 \\
\hline Extração de petróleo, gás, carvão e outros & 355.646 & -130.934 & -59.878 & 1.969 .476 & -2.134 .310 \\
\hline Minerais não metálicos & -303.318 & -2.039 .949 & -751.702 & 2.608 .997 & 485.973 \\
\hline \multirow{2}{*}{$\begin{array}{l}\text { Siderurgia e metalúrgicos ferrosos ou não } \\
\text { Fabricação e manutenção de máquinas e } \\
\text { tratores }\end{array}$} & -594.695 & -1.082 .250 & -1.333 .764 & 5.427 .600 & -2.416 .891 \\
\hline & -426.677 & -2.407 .642 & -759.275 & 1.946 .882 & 1.646 .713 \\
\hline Material elétrico e eletrônico & 983.527 & -2.971 .303 & -1.230 .843 & 5.271 .737 & -2.053 .118 \\
\hline Automóveis, outros veículos e peças & -252.270 & -4.196 .497 & -1.681 .571 & 6.906 .322 & -775.985 \\
\hline Madeira mobiliário & 647.372 & -1.860 .483 & -163.159 & -1.131 .492 & 2.507 .761 \\
\hline Ind. de papel e gráfica & -62.360 & -1.760 .502 & -1.187 .432 & 3.372 .486 & -362.191 \\
\hline Indústria da borracha & -161.138 & -677.771 & -295.868 & 1.251 .564 & -116.787 \\
\hline Químicos diversos & 87.053 & -1.044 .558 & -1.494 .354 & 5.966 .355 & -3.514 .496 \\
\hline Refino de petróleo & -2.415 .262 & 3.365 .331 & -4.045 .912 & 3.252 .097 & -156.254 \\
\hline Farmacêutica e veterinária & 71.680 & -3.013 .166 & -1.299 .072 & 7.008 .008 & -2.767 .450 \\
\hline Artigos de plástico & 135.533 & -1.116 .408 & -691.637 & 1.710 .566 & -38.054 \\
\hline Indústria têxtil & -296.076 & -100.827 & -655.662 & 1.842 .469 & -789.905 \\
\hline Artigos vestuário & -482.395 & -930.003 & -686.318 & 1.518 .951 & 579.765 \\
\hline Fabricação do calçados & -125.721 & 142.661 & -166.920 & -980.221 & 1.130 .201 \\
\hline Produtos alimentares & -600.648 & -2.089 .020 & 544.428 & -6.614 .183 & 8.759 .421 \\
\hline Indústrias diversas & 41.868 & -1.018 .080 & -427.280 & -120.047 & 1.523 .539 \\
\hline SIUP & 323.350 & -120.969 & -263.480 & -2.984 & 64.083 \\
\hline Construção civil & 927.817 & 1.847 .293 & 1.148 .635 & -1.963 .910 & -1.959 .835 \\
\hline Comércio & -198.895 & -455.321 & 20.065 & 1.513 .684 & -879.533 \\
\hline Transporte & 213.812 & 373.419 & 62.072 & -1.106 .750 & 457.447 \\
\hline Comunicações & -92.936 & 218.260 & 193.142 & 220.098 & -538.564 \\
\hline Instituições financeiras & -213.562 & -521.084 & 710.455 & 1.047 .165 & -1.022 .974 \\
\hline Serviços prestados às famílias & 236.218 & 608.910 & -91.495 & 414.827 & -1.168 .460 \\
\hline Serviços prestados às empresas & -41.535 & -358.785 & -611.051 & 1.889 .895 & -878.525 \\
\hline Aluguel imóveis & -684.690 & -2.538 .348 & -993.911 & 6.587 .613 & -2.370 .664 \\
\hline Administração Pública & -17.493 & -240.644 & 648.025 & 101.326 & -491.214 \\
\hline Serviços Privados não mercantis & - & - & - & - & - \\
\hline Total & 749.619 & -22.170 .637 & -10.971 .501 & 34.060 .284 & -1.667 .765 \\
\hline
\end{tabular}

Fonte: Elaborada a partir dos dados obtidos por Guilhoto et al., op. cit. (2003)

O setor de refino de petróleo foi o que apresentou o maior superávit no comércio da região Nordeste com as demais regiões, seguido da agropecuária. A grande importância do setor de refino de petróleo para essa região deve-se basicamente à presença do Pólo Petroquímico da Bahia. O setor tem desempenhado um papel importante nas exportações do Nordeste para as demais regiões, como se pode verificar 
na Tabela 12. Os produtos dos setores de automóveis, de outros veículos e peças, de farmacêutica e veterinária e de material elétrico e eletrônico foram os responsáveis pelos maiores déficits observados no comércio do Nordeste com as demais regiões.

Os maiores superávits comerciais no Centro-Oeste deveram-se basicamente aos segmentos ligados à agropecuária e à construção civil (Tabela 12). O refino de petróleo foi o setor responsável pelo maior déficit no comércio observado entre o Centro-Oeste e as demais regiões, seguido do setor automóveis, outros veículos e peças e químicos diversos.

O Sudeste foi a única região onde se verificou um déficit nas transações comerciais ligadas à agropecuária. O setor de produtos alimentares é o segundo setor a apresentar o maior déficit comercial na região. Os principais setores na geração de superávit, no comércio doméstico do Sudeste foram: farmacêutica e veterinária; automóveis, outros veículos e peças e químicos diversos, de acordo com os dados da apresentados na Tabela 12 .

As atividades ligadas ao agronegócio - produtos alimentares, agropecuária e madeira e mobiliário - foram as que mais se destacaram na geração de superávit comercial na região Sul (ver Tabela 12). Os principais setores deficitários na região foram: químicos diversos; farmacêutica e veterinária e siderurgia e metalurgia, de ferrosos ou não.

As análises dos saldos das transações realizadas entre as regiões demonstraram a grande importância da agropecuária na geração de superávit para quase todos as regiões, com exceção do Sudeste, onde o setor se apresentou como deficitário. Os outros setores que mereceram destaque foram: automóveis, outros veículos e peças; químicos diversos; refino de petróleo e farmacêutica e veterinária, dentre outros.

As principais regiões a comercializarem no mercado externo foram a Sudeste e a Sul. Com relação ao saldo das transações comerciais com o exterior, pôde-se verificar que o maior déficit foi observado na região Nordeste e a região com maior superávit foi a Sudeste. No comércio doméstico, pôde-se verificar que a região Sudeste foi a principal 
exportadora de produtos para as outras regiões e, também, a principal região de destino das exportações realizadas pelas demais regiões. Quando se observa o saldo do comércio realizado entre as regiões, verifica-se que o Sudeste e o Norte são as únicas regiões a apresentar superávit nas transações analisadas. Verificou-se, também, que o superávit do Sudeste foi quarenta e cinco vezes superior ao observado no Norte. O Nordeste foi a região que apresentou o mais elevado déficit duas vezes maior que o verificado no Centro-Oeste, região com o segundo maior déficit. Os resultados demonstram um grande desequilíbrio no comércio doméstico brasileiro, com forte concentração na região Sudeste, tanto no superávit quanto nas transações comercias.

Um dos grandes problemas que as regiões encontram em decorrência dos desequilíbrios em suas transações, tanto no mercado interno quanto no mercado externo, diz respeito à forma de financiamento de seus déficits. No caso da região Sudeste, podese supor que seu déficit no mercado externo esteja sendo financiado pelo seu superávit no comércio doméstico. O contrário pode estar sendo observado no Sul, que se apresenta como deficitário no mercado interno e superavitário no comércio com o exterior. Como ficam as regiões Nordeste e Centro-Oeste, que se mostram como deficitárias em ambos os mercados? Esse é um assunto que poderá ser abordado em trabalhos futuros, pois apesar de importante, foge ao tema proposto no presente trabalho.

Com relação ao mercado doméstico, cabe ressaltar a importância da reforma fiscal que está sendo discutida e votada este ano no Congresso e no Senado. Faz muita diferença para as regiões, principalmente as com maiores superávits e déficits, se o ICMS será cobrado na origem ou no destino. Essa matéria merece muita atenção por parte dos governantes, da população e do legislativo, pois se trata de uma forma indireta de: distribuição de renda, de correção das desigualdades regionais e de eliminação de uma forma de concorrência improdutiva entre os estados, a denominada "guerra fiscal".

Depois de realizado um breve relato da evolução da economia brasileira, das desigualdades regionais e do comportamento do comércio doméstico e internacional, o próximo capítulo tem como objetivo descrever as teorias de comércio internacional que buscam as justificativas para a existência de comércio entre os países. 


\section{REVISÃO DE LITERATURA}

Este capítulo tem o objetivo de apresentar, de forma resumida, a evolução da teoria de comércio internacional, com relação à justificativa para a existência de comercialização entre nações. Traz também a revisão de alguns trabalhos desenvolvidos com base na teoria de Heckscher-Ohlin.

\subsection{Teorias de comércio internacional}

Na teoria de comércio internacional, tenta-se responder às seguintes questões: o que determina o comércio entre os países e se ele traz algum beneficio para os mesmos. Para tentar responder a essas e a outras questões, algumas teorias foram desenvolvidas. Nesta seção, são apresentadas as principais teorias que tratam de questões como as acima expostas, e mais especificamente as teorias de Heckscher-Ohlin e de comércio intra-indústria utilizadas no presente trabalho.

\subsubsection{O desenvolvimento das principais teorias}

As primeiras idéias estabelecidas sobre o comércio internacional foram desenvolvidas pelos mercantilistas, entre os séculos XVI e XVIII. Na sua concepção, o comércio entre nações era visto com restrições, já que segundo a doutrina mercantilista, o meio mais importante para enriquecer um país era a aquisição e a reserva de metais preciosos, principalmente o ouro. As exportações eram vistas favoravelmente, desde que vendidas em ouro; já as importações eram mal vistas, pois implicavam a saída da fonte de riqueza do país, os metais preciosos. Para os mercantilistas, o comércio externo 
"tinha que ser ajustado, controlado e restrito e não se encontrava nenhuma irtude em ter um amplo volume de comércio" (Södersten 1979, p.14).

A economia clássica desenvolve-se nesse cenário, e seus principais representantes, Adam Smith (séc. XVIII) e David Ricardo (séc. XIX), mostram posições contrárias ao mercantilismo e favoráveis ao comércio entre as nações. Adam Smith (1983) argumentava que um país poderia se beneficiar do comércio, com base na pressuposição de que a riqueza das nações era resultado do aumento na produtividade do trabalho. Gonçalves et al (1998, p.12) descrevem, da seguinte forma, a linha de raciocínio seguida por Adam Smith, para justificar o comércio entre as nações:"A riqueza das nações é resultado do aumento da produtividade do trabalho. A divisão do trabalho é resultado da propensão da natureza humana de trocar, negociar e vender um produto em troca de outro. A divisão do trabalho, no entanto, é limitada pela extensão do mercado. Uma vez que o comércio internacional aumenta o mercado para os produtos produzidos domesticamente, ele permite o aprofundamento da divisão do trabalho, contribuindo para aumentar a riqueza das nações".

De acordo com Smith (1983), no comércio estabelecido entre as nações, o país deveria exportar as mercadorias que conseguisse produzir mais barato que os demais e importar aquelas que produzisse internamente a um custo maior. Dessa forma, o país produziria mais dos bens e serviços que faria com maior eficiência, utilizando menos horas de trabalho, e reduziria a sua produção onde não apresentasse uma eficiência tão elevada. Como resultado, o país poderia consumir mais produtos do que seria capaz sem o comércio entre as nações. Essa é a idéia central da teoria de vantagem absoluta desenvolvida pelo autor.

Uma das principais contribuições atribuídas a David Ricardo (1982), para a teoria do comércio internacional, foi o desenvolvimento da teoria da vantagem comparativa. A proposição dessa teoria é que o comércio bilateral sempre se apresenta mais vantajoso que a autarcia para duas economias, cujas estruturas de produção ou cujas tecnologias sejam diferenciadas. 
Considerando-se dois países, Inglaterra (I) e Portugal (P), produzindo cada um dois produtos, vinho (V) e tecido (T). Se a Inglaterra empregar uma quantidade $L_{V}^{I}$ de trabalho para produzir o vinho e $L_{T}^{I}$ de trabalho para produzir o tecido; e Portugal empregar as quantidades $L_{V}^{P} L_{T}^{P}$ de trabalho para a produção de vinho e tecido, respectivamente. De acordo com a teoria de vantagem comparativa, o comércio entre os países seria vantajoso desde que:

$$
\frac{L_{V}^{I}}{L_{T}^{I}} \neq \frac{L_{V}^{P}}{L_{T}^{P}}
$$

ou seja, desde que as quantidades relativas de trabalho empregado na produção de vinho e de tecido fossem distintas. Mesmo que Portugal necessitasse de menos horas de trabalho para a produção de vinho e de tecido, o comércio entre essas nações, segundo Ricardo, poderia ser justificado, desde que a desigualdade da equação (1) fosse observada.

O modelo de Ricardo difere do modelo de vantagem absoluta, apresentado por Smith, por não considerar apenas as quantidades absolutas de trabalho, $\mathrm{L}_{V}$ e $\mathrm{L}_{\mathrm{T}}$, utilizadas na produção dos bens em ambos os países. Para Ricardo, as quantidades relativas, $\mathrm{Lv}_{\mathrm{V}} / \mathrm{LT}_{\mathrm{T}}$, determinam as vantagens do comércio, o que amplia a possibilidade de comércio entre as nações. Considerando apenas as vantagens absolutas, o comércio entre Portugal e Inglaterra não seria realizado, desde que Portugal produzisse, a um custo menor, ambos os bens.

A teoria de comércio internacional evoluiu, no sentido de incentivar o comércio entre as nações. Os mercantilistas, entre os séculos XVI e XVIII, não viam o comércio entre países como uma virtude. Já Smith, no final do século XVIII, argumentava que o comércio seria benéfico, desde que houvesse vantagem absoluta na produção de um dos bens. Ricardo, no início do século XIX, mostra que, mesmo que um país tenha vantagem absoluta na produção de ambos os bens, o comércio entre dois países se justifica, desde que haja vantagem comparativa, ou seja, desde que as quantidades relativas de trabalho, empregadas na produção dos bens, fossem diferenciadas para essas duas economias. 
Surgiu, no século $\mathrm{XX}$, a discussão da teoria neoclássica, com relação ao comércio exterior. Essa tem no modelo de Heckscher-Ohlin, o qual será apresentado na póxima seção, a sua principal contribuição. De acordo com Gonçalves et al. (1998), a teoria de Heckscher-Ohlin é uma discussão mais elaborada dos fundamentos do conceito de vantagens comparativas e dos ganhos com o comércio estabelecido pelas nações.

\subsubsection{A teoria de Heckscher-Ohlin}

Os princípios básicos desta teoria, de acordo com Gonçalves et al (1998), foram formulados originalmente por Eli Filip Heckscher, em 1919, e posteriormente desenvolvidos por seu ex-aluno, Bertil G. Ohlin, em 1933. Por isso, passou a ser conhecida como teoria ou teorema de Heckscher-Ohlin. Segundo essa teoria, a dotação de recursos difere entre os países e o comércio internacional é conduzido, basicamente, por essas diferenças, ou seja, o comércio internacional seria, em última análise, uma troca de fatores abundantes por fatores escassos, em cada um dos países. No caso simples de dois fatores, dois produtos e duas regiões, o comércio estaria baseado na troca de bens com produção relativamente mais barata em cada região, ou seja, aqueles cuja produção requer relativamente maior quantidade do fator abundante em termos domésticos.

A estrutura lógica da teoria de Heckscher-Ohlin tem como base quatro teoremas, como pode ser observado na Figura 13.

A diferença na dotação relativa dos fatores de produção entre os países implica diferente remuneração relativa desses fatores. Os preços relativos dos fatores escassos são maiores, em relação aos preços relativos dos fatores abundantes. Caso os fatores de produção pudessem ter completa mobilidade entre os países, o trabalho poderia migrar em busca de melhores salários, e o capital poderia deslocar-se para os países em que seu retorno fosse maior. Esse processo eliminaria as diferenças nas dotações e, como conseqüência, nas remunerações relativas dos fatores entre os países. O comércio de 
bens pode ser, de certa forma, considerado como uma troca que traz embutida a migração indireta dos fatores de produção contidos na elaboração dos mesmos.

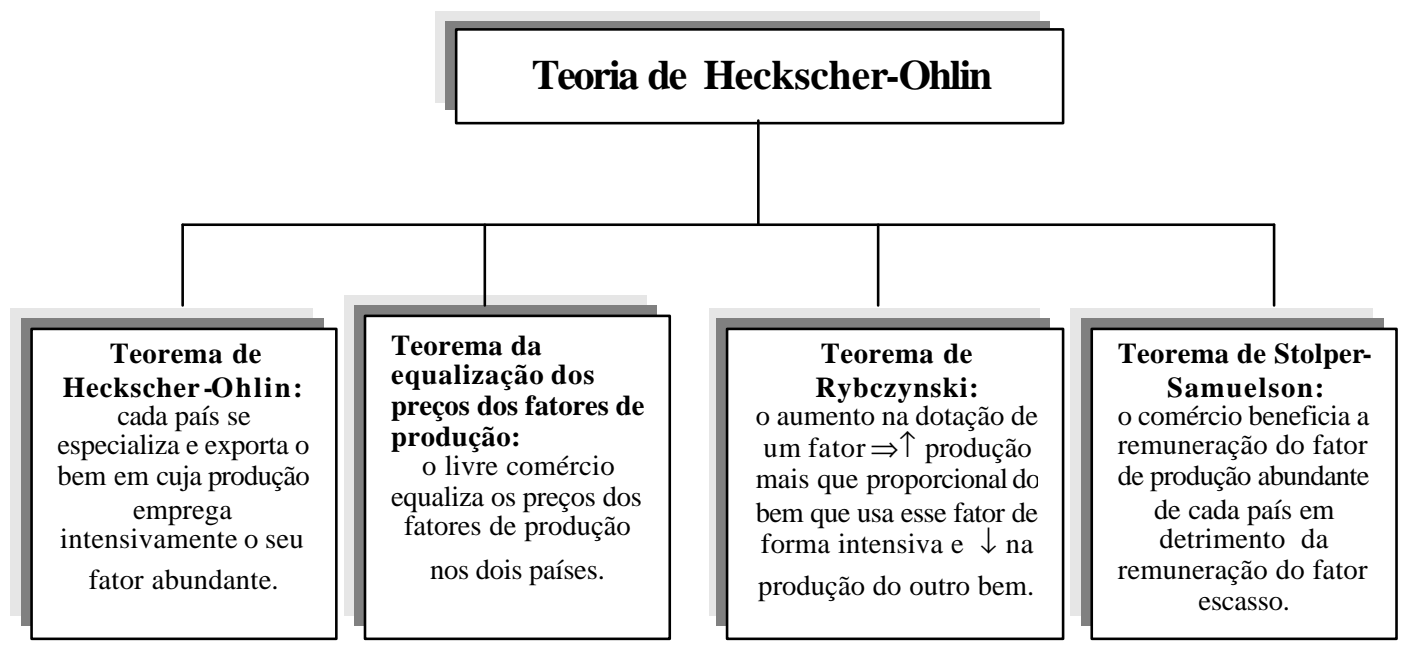

Figura 13 - Teoremas que compõem a teoria de Heckscher-Ohlin.

De acordo com o teorema de equalização dos preços dos fatores de produção, desenvolvido por Paul Samuelson (1948), o comércio de mercadorias tem o mesmo efeito sobre os salários e os retornos do capital que a mobilidade dos fatores, ou seja, o comércio de bens iguala a remuneração dos fatores de produção. Cabe ressaltar que esse teorema é válido somente se houver o livre comércio entre os países.

A relação entre os preços dos bens e a remuneração dos fatores é tratada no teorema de Stolper-Samuelson. Ele foi proposto por Stolper \& Samuelson (1941) onde os autores discutiram o efeito de uma tarifa que alterasse o preço de um produto importado, sem afetar os preços mundiais. Nesse caso, de acordo com Gonçalves et al. (1998), haveria uma transferência de renda para o fator usado mais intensivamente na produção do bem protegido. A remuneração desse fator aumentaria, porque, com a medida protecionista, a produção do bem protegido seria estimulada, o que levaria a um aumento mais que proporcional na demanda do fator utilizado de forma mais intensiva, 
causando um aumento maior em sua remuneração, em relação aos demais fatores utilizados.

O mesmo raciocínio apresentado acima é válido, quando se considera a especialização da produção do país em bens que requerem, em seu processo produtivo, o fator de produção relativamente abundante no país. Com isso, há um aumento mais que proporcional na demanda por esse fator, o que, por sua vez, leva ao aumento da remuneração do mesmo, devido àhi pótese de pleno emprego dos fatores.

O teorema de Rybczynski discute o efeito da variação das disponibilidades dos fatores sobre as quantidades produzidas. De acordo com esse teorema, o aumento da oferta de um fator de produção leva ao acréscimo da produção do país e do bem que utiliza, de forma mais intensiva, esse fator. A validade desse teorema somente é confirmada se a tecnologia de produção não for alterada.

O teorema de Heckscher-Ohlin, presente na Figura 13, será apresentado em maiores detalhes próxima seção, por se tratar de um dos principais objetos de estudo do presente trabalho. Cabe lembrar que esse teorema, juntamente os demais apresentados nesta seção, compõem a teoria de Heckscher-Ohlin.

\subsubsection{Teorema de Heckscher-Ohlin}

De acordo com o teorema de Heckscher-Ohlin, cada país se especializa e exporta o bem que requer utilização mais intensiva de seu fator de produção abundante. Os pressupostos que sustentam o teorema de Heckscher-Ohlin são descritos na seqüência.

1. As funções de produção contam com dois fatores, trabalho (L) e capital $(\mathrm{K})$;

2. Existem dois bens, V e E, que são produzidos em dois países, $\mathrm{F}$ e M;

3. Os fatores de produção $\mathrm{K}$ e $\mathrm{L}$ possuem completa mobilidade entre os setores produtivos de um mesmo país, sem ônus, e o comércio é livre de barreiras, ou 
seja, as mercadorias fluem de um país para outro sem custos de transporte, ou qualquer outro impedimento;

4. As tecnologias de produção são idênticas nos dois países, ou seja, o mesmo conjunto de técnicas ou processos de produção estão disponíveis para todos os produtores de um mesmo bem, independente do país e sem custos;

5. Os fatores de produção são utilizados em combinações diferentes para a produção de $\mathrm{V}$ e E. A função de produção de $\mathrm{V}$ é intensiva em trabalho e a função de produção de E é intensiva em capital, tanto interna quanto externamente, e ambas apresentam retornos constantes de escala.

Esse pressuposto é utilizado na teoria para evitar que ocorra a possibilidade de reversão na intensidade ${ }^{6}$ do uso dos fatores para o mesmo produto, interna e externamente. Caso isso venha a ocorrer, o padrão de comércio entre os dois países fica indeterminado, não sendo aplicável à teoria de Heckscher-Ohlin, pois o país poderá escolher a forma de produzir que melhor se adaptar a sua disponibilidade de fatores;

6. A dotação relativa de fatores difere entre países. No país F, o capital é relativamente abundante, e, no país $\mathrm{M}$, o trabalho é relativamente abundante. $\mathrm{O}$ teorema de Heckscher-Ohlin não se baseia apenas nas diferenças das proporções entre as funções de produção, mas também na dotação relativa dos fatores de produção nos países em questão. Duas maneiras são apresentadas por Carvalho \& Silva (2000), para definir a dotação relativa de fatores nos países. A primeira leva em conta sua disponibilidade física. Pode-se afirmar que o país F é abundante em capital se

$$
\frac{K_{F}}{L_{F}}>\frac{K_{M}}{L_{M}}
$$

A segunda compara os preços relativos dos fatores de produção, ou seja, a razão entre os preços de trabalho (salário, w) e do capital (remuneração do capital, r) dos dois países. Como a produção dos bens demanda ambos os fatores de produção, mesmo que

\footnotetext{
${ }^{6}$ A reversão na intensidade de uso dos fatores ocorre, quando há pelo menos duas tecnologias distintas para a produção de determinado bem, sendo uma intensiva em capital e a outra intensiva em trabalho.
} 
em proporções diferentes, pode-se esperar que a remuneração do fator escasso seja relativamente maior que a do fator abundante. Se a hipótese inicial é que o capital é relativamente abundante em $\mathrm{F}$, e o trabalho, em $\mathrm{M}$, pode-se confirmar essa hipótese desde que

$$
\frac{r_{F}}{w_{F}}<\frac{r_{M}}{w_{M}}
$$

Cabe observar que não se trata nem da quantidade absoluta dos fatores, nem dos níveis absolutos de salários e remuneração do capital, em cada um dos países, para caracterizar a abundância relativa, mas sim a relação entre essas quantidades. Uma forma alternativa para observar a dotação relativa de fatores, quando há mais de dois fatores de produção, é apresentada por Vanek $(1968)^{7}$; daí se desenvolveu o teorema de Heckscher-Ohlin-Vanek. A abundância relativa dos fatores é definida, comparando-se a disponibilidade que um país detém de um determinado fator com a disponibilidade média global. Caso seja maior, há abundância; se for menor, há escassez .

Uma análise gráfica que permite classificar diversos países, de acordo com suas intensidades fatoriais (terra e recursos naturais (RN), trabalho (L) e capital (K)), foi desenvolvida por Leamer (1987) e denominada "método dos triângulos de dotação";

7. As preferências dos consumidores são iguais nos dois países;

8. A balança comercial dos dois países está sempre em equilíbrio. Com relação a este pressuposto, Gonçalves et al (1998, p.24) argumentam que, embora não sendo muito realista, a violação desse pressuposto não provoca grande dano à interpretação do modelo, alterando apenas o ponto de equilíbrio de livre comércio.

Esses oito pressupostos apresentados dão sustentação teórica ao teorema de Heckscher-Ohlin. A demonstração do teorema encontra-se descrita na próxima seção.

\footnotetext{
${ }^{7}$ Um melhor detalhamento sobre esta questão pode observado em Leamer (1984) e Machado (1997).

${ }^{8}$ A metodologia adotada no presente trabalho, para verificar a dotação relativa dos fatores, encontra-se descrita em maiores detalhes na seção 3.1.2.3.

${ }^{9}$ Esse método não será descrito em maiores detalhes, por não ser utilizado no presente trabalho. Para maiores informações, ver Leamer (1987).
} 


\subsubsection{Demonstração e comprovação do teorema de Heckscher-Ohlin ${ }^{10}$}

A dotação total de fatores, em determinado país, é dada pela soma das quantidades de capital e trabalho utilizadas na produção de ambos os bens. Os estoques de capital e de trabalho podem ser dados pelo seguinte sistema de equações:

$$
\begin{aligned}
& K=a_{k V} V+a_{k E} E \\
& L=a_{L V} V+a_{L E} E
\end{aligned}
$$

onde $\mathrm{K}$ = estoque total de capital do país; $\mathrm{L}=$ estoque total de trabalho no país; $\mathrm{V}=$ quantidade total produzida do bem $\mathrm{V} ; \mathrm{E}=$ produção total do bem $\mathrm{E}$ e os coeficientes $\mathrm{a}_{\mathrm{j}}$ são definidos como a quantidade relativa do fator i necessária à produção de uma unidade do bem j. Esses coeficientes são os mesmos, quando se considera dois países, no caso $\mathrm{F}$ e M, devido à pressuposição de que as tecnologias de produção são idênticas.

$\mathrm{Na}$ exposição que se segue, o país $\mathrm{F}$ é mantido como referencial e são definidas as seguintes matrizes:

$$
G=\left[\begin{array}{c}
K \\
L
\end{array}\right] \quad X=\left[\begin{array}{c}
V \\
E
\end{array}\right] \quad \quad \mathbf{A}=\left[\begin{array}{ll}
a_{k V} & a_{k E} \\
a_{L V} & a_{L E}
\end{array}\right]
$$

onde $G$ é o vetor dos estoques dos fatores de produção; $X$, o vetor dos bens produzidos e A, a matriz dos coeficientes de intensidade dos fatores.

O sistema de equações (2) pode ser representado em linguagem matricial:

$$
G=\mathbf{A} X \quad \Rightarrow \quad X=\mathbf{A}^{-1} G
$$

Para que a inversa de A exista, é necessário que akv/aLv $\neq \mathrm{a}_{\mathrm{kE}} / \mathrm{aLE}^{11}$, ou seja, é necessário que a tecnologia utilizada para a produção de $\mathrm{V}$ seja diferente daquela utilizada na produção de E. Como essas equações são lineares, pode-se fazer a extrapolação para o mundo, por agregação. A produção global pode ser definida como na equação (4), onde $\bar{X}$ representa a produção global e $\bar{G}$ os estoques globais dos

\footnotetext{
${ }^{10}$ A demonstração apresentada neste item está baseada no trabalho de Leamer (1984, p. 3-11)

11 A condição necessária para que a inversa de A exista é que o seu determinante seja diferente de zero e, para tanto, não pode haver relação linear entre as linhas e as colunas da matriz.
} 
fatores de produção. A matriz A não muda em decorrência da pressuposição do modelo de que as tecnologias de produção são idênticas para produtos idênticos.

$$
\bar{X}=\mathbf{A}^{-1} \bar{G}
$$

Uma das pressuposições da teoria é que as funções de utilidade ou de preferência dos consumidores devem ser iguais em ambos os países ${ }^{12}$, o que significa que o gosto dos indivíduos é o mesmo. Dessa forma, a proporção de consumo de cada bem deve ser a mesma em ambos os países, podendo-se chegar à seguinte relação:

$$
C=s \bar{X}
$$

onde $C$ é o vetor de consumo, idêntico em ambos países, e s é um escalar que indica a proporção de consumo doméstico no consumo global.

Para a determinação de $\mathrm{s}$, faz-se necessário supor que o país esteja em equilíbrio comercial e que seu consumo corresponda à sua produção, $X=C$. Considerando $p$ como o vetor dos preços dos bens $p=\left[\begin{array}{l}p_{v} \\ p_{E}\end{array}\right]$, multiplicando-o de ambos os lados em $X=C$, e substituindo $C$ pela equação (5), obtém-se $p^{\prime} X=p^{\prime} C=s p^{\prime} \bar{X}$. A partir dessa relação, pode-se obter s:

$$
s=\left(p^{\prime} \bar{X}\right)^{-1} p^{\prime} X
$$

Outra pressuposição do teorema do Heckscher-Ohlin é o equilíbrio na balança comercial de cada país, o qual é o resultado de soma zero das exportações líquidas (superávit e déficit) de cada setor ${ }^{13}$. $\mathrm{O}$ volume da produção, do país $\mathrm{F}$, não consumido internamente é dado por:

$$
T=X-C
$$

substituindo (3), (4) e (5) em (7), tem-se:

\footnotetext{
${ }^{12}$ Nos modelos de comércio internacional, as preferências dos consumidores, de acordo com Carvalho e Silva (2000), são representadas pelas curvas de indiferença nacionais. Essas são obtidas pela agregação das curvas de indiferença individuais.

${ }^{13} \mathrm{O}$ setor que produz E no país $\mathrm{F}$ deverá ser superavitário e o que produz V, deficitário.
} 


$$
T=\mathbf{A}^{-1} G-s \bar{X}=\mathbf{A}^{-1} G-s \mathbf{A}^{-1} \bar{G}
$$

colocando $\mathrm{A}^{-1}$ em evidência e substituindo $G$ e $\bar{G}$ pelos respectivos vetores de estoques de fatores do produção do país F e global, tem-se:

$$
T=\mathbf{A}^{-1}(G-s \bar{G})=\mathbf{A}^{-1}\left[\begin{array}{c}
K-s \bar{K} \\
L-s \bar{L}
\end{array}\right]
$$

colocando $\bar{K}$ e $\bar{L}$ em evidência:

$$
T=\mathbf{A}^{-1}\left[\begin{array}{c}
\bar{K}(K / \bar{K}-s) \\
\bar{L}(L / \bar{L}-s)
\end{array}\right]
$$

onde: $T=\left[\begin{array}{l}T_{V} \\ T_{E}\end{array}\right]$ é o vetor das exportações líquidas de $\mathrm{F}$, para os bens $\mathrm{V}$ e E, produzidos por esse país. Como $\mathrm{F}$ é abundante em capital, e E é intensivo em capital e $\mathrm{V}$, em trabalho, basta que $T_{E}>0$ e $T_{V}<0$ para que se comprove o teorema de Heckscher-Ohlin, ou seja, que o país $\mathrm{F}$ é exportador líquido de bens intensivos em capital, seu recurso abundante, e importador líquido de bens intensivos em trabalho, seu recurso escasso internamente.

Com a apresentação do teorema de Heckscher-Ohlin e a descrição da forma de verificar se o país é exportador líquido de bens intensivos em seu fator abundante, e importador líquido de bens intensivos em seu fator escasso, feita nesta seção, faz-se necessária a descrição da metodologia a ser utilizada na determinação da abundância relativa dos fatores, assunto da seção seguinte.

\subsubsection{Determinação da abundância relativa dos fatores ${ }^{14}$}

Para que a validade do teorema de Heckscher-Ohlin seja constatada, faz-se necessário calcular a abundância relativa de fatores em cada um dos países. O objetivo

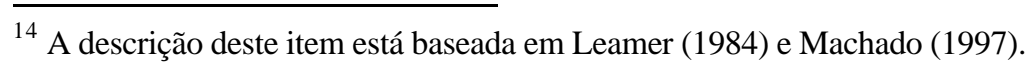


desta seção é apresentar algumas formas de verificar a abundância de fatores, tendo o comércio como referencial.

A equação (10) foi reescrita por Vanek (1968) da seguinte forma:

$$
\mathbf{A} T=G-s \bar{G}
$$

Do lado esquerdo da equação 11, podem-se verificar as quantidades dos fatores de produção $\mathrm{K}$ e L, incorporadas nas exportações líquidas. A abundância relativa de um determinado fator pode ser definida do lado direito da equação. O país $\mathrm{F}$ pode ser considerado relativamente abundante no fator de produção $K$, quando sua participação na oferta global de K superar sua participação no consumo, ou seja, $\frac{K}{\bar{K}}>s$.

Leamer (1984), com base na equação (11), define as seguintes equações:

$$
\begin{aligned}
& K_{T}=K-s \bar{K} \\
& L_{T}=L-s \bar{L}
\end{aligned}
$$

onde $\mathrm{K}_{\mathrm{T}}$ e $\mathrm{L}_{\mathrm{T}}$ são as quantidades de capital e trabalho, incorporadas no fluxo líquido de comércio (exportação menos importação). Manipulando as equações (12 a) e (12b), Leamer (1984) apresenta o teorema que define quando um país é abundante em capital: o capital é relativamente abundante em relação ao trabalho, $\frac{K}{\bar{K}}>\frac{L}{\bar{L}}$, se e somente se:

$$
\frac{K}{K-K_{T}}>\frac{L}{L-L_{T}}
$$

ou seja, se a razão entre o uso total de $\mathrm{K}$ na economia e a diferença entre esse uso e o volume de capital presente nas exportações líquidas $\left(\mathrm{K}-\mathrm{K}_{\mathrm{T}}\right)$ for maior do que essa razão observada para o fator L. Leamer (1984) reescreve a equação (13) e apresenta três formas equivalentes de verificar a abundância de fatores, tendo o comércio como referencial. Considerando-se que o total de capital utilizado em um país se divide entre a parcela incorporada na produção de bens e serviços consumidos internamente $\left(\mathrm{K}_{\mathrm{C}}\right)$ e a parcela dos bens e serviços comercializados com o exterior $\left(\mathrm{K}_{\mathrm{T}}\right)$, a utilização total do 
capital pode ser representada como $\mathrm{K}=\mathrm{K}_{\mathrm{C}}+\mathrm{K}_{\mathrm{T}}$. $\mathrm{O}$ mesmo raciocínio pode ser aplicado para o fator de produção trabalho $\mathrm{L}=\mathrm{Lc}+\mathrm{L}$. A equação (13) pode ser reescrita da seguinte forma:

$$
\frac{K}{L}>\frac{K_{C}}{L_{C}}
$$

A partir da relação encontrada na equação (13 a), pode-se verificar que o país é relativamente abundante em capital, quando a razão entre o uso total dos fatores supera a razão para o consumo doméstico. Ou se pode, também, dizer que a produção total é relativamente mais intensiva em capital que seu consumo doméstico.

Considerando as quantidades de $\mathrm{K}$ e $\mathrm{L}$ incorporadas no fluxo líquido de comércio, $\mathrm{K}_{\mathrm{T}}$ e $\mathrm{L}_{\mathrm{T}}$, podem-se ter quatro possibilidades, com relação aos fatores de produção:

a) o país pode ser exportador líquido de capital $K_{\Upsilon}>0$ e importador líquido de trabalho $\mathrm{L}_{\mathrm{T}}<0$;

b) o país pode ser exportador líquido de trabalho $\mathrm{L}_{\mathrm{T}}>0$ e importador líquido de capital $\mathrm{K}_{\mathrm{T}}<0$;

c) o país pode ser exportador líquido de ambos os fatores $\mathrm{K}_{\mathrm{T}}>0$ e $\mathrm{L}_{\mathrm{T}}>0$ e

d) o país pode ser importador líquido tanto de trabalho $\mathrm{L}_{\mathrm{T}}<0$ quanto de capital $\mathrm{K}_{\mathrm{T}}<0$.

Nos dois primeiros casos, quando $\mathrm{K}_{\mathrm{T}}$ e $\mathrm{L}_{\mathrm{T}}$ têm sinais opostos, não são necessários cálculos adicionais para determinar a abundância relativa dos fatores. O fator que tiver o sinal positivo é o relativamente abundante. Nos casos em que os sinais são semelhantes, c e d, faz-se necessário verificar qual fator é mais abundante. Uma forma de cálculo foi apresentada por Leamer (1984) e surge a partir da manipulação da equação (13):

$$
K\left(L-L_{T}\right)>L\left(K-K_{T}\right)=-K L_{T}>-L K_{T}
$$


Assumindo a hipótese de que o país seja exportador líquido, tanto de trabalho quanto de capital, ou seja, $\mathrm{K}_{\mathrm{T}}>0$ е $\mathrm{L}_{\mathrm{T}}>0$, de acordo com Machado (1997, p. 51), “o comércio indica que há abundância relativa de capital quando $\mathrm{K}_{\mathrm{T}} / \mathrm{L}_{\mathrm{T}}>\mathrm{K} / \mathrm{L}$, isto é, quando as exportações líquidas são mais intensivas em capital que a produção, ou quando $\mathrm{K}_{\mathrm{T}} / \mathrm{K}>\mathrm{L}_{\mathrm{T}} / \mathrm{L}$, isto é, quando a quantidade relativa de capital exportado supera a quantidade relativa de trabalho exportado". Caso o país seja considerado importador líquido de ambos os fatores, $\mathrm{K}_{\mathrm{T}}<0$ e $\mathrm{L}_{\mathrm{T}}<0$, a abundância relativa de capital será observada quando $\mathrm{K}_{\mathrm{T}} / \mathrm{LT}_{\mathrm{T}}<\mathrm{K} / \mathrm{L}$ ou $\mathrm{K}_{\mathrm{T}} / \mathrm{K}<\mathrm{L}_{\mathrm{T}} / \mathrm{L}$.

A equação (13) também pode ser reescrita da seguinte forma:

$$
-\left(K_{C}+K_{T}\right) L_{T}>-\left(L_{C}+L_{T}\right) K_{T} \Rightarrow-K_{C} L_{T}>-L_{C} K_{T}
$$

Considerando o país exportador líquido de capital e trabalho, $\mathrm{K}_{\mathrm{T}}>0$ e $\mathrm{L}_{\mathrm{T}}>0$, para que ele seja considerando relativamente abundante em capital, faz-se necessário que $\mathrm{K}_{\mathrm{T}} / \mathrm{L}_{\mathrm{T}}>\mathrm{K}_{\mathrm{d}} \mathrm{L}_{\mathrm{C}}$, isto é, que a relação capital trabalho contida o comércio supere a relação presente no consumo doméstico. No caso de o país ser importador líquido de capital e trabalho $\mathrm{K}_{\mathrm{T}}<0$ e $\mathrm{L}_{\mathrm{T}}<0$, ele apresenta abundância relativa em capital quando $\mathrm{K}_{\mathrm{T}} / \mathrm{L}_{\mathrm{T}}<\mathrm{K}_{\mathrm{d}} / \mathrm{L}_{\mathrm{C}}$, ou ainda, $\mathrm{K}_{\mathrm{T}} / \mathrm{K}_{\mathrm{C}}<\mathrm{L}_{\mathrm{T}} / \mathrm{L}_{\mathrm{C}}$, ou seja, o consumo relativo de trabalho presente nas importações líquidas é maior que o consumo relativo de capital.

Depois de determinada a abundância relativa dos fatores pode-se verificar se as exportações e importações do país em questão se encontram em conformidade com o teorema de Heckscher-Ohlin. Para que o teorema seja constatado, faz-se necessário verificar se as exportações utilizam, em seu processo produtivo, um volume relativamente maior do fator de produção considerado abundante, em relação às importações.

O objetivo da seção 3.1 foi apresentar as principais teorias de comércio internacional que buscam justificar a existência de comércio entre as nações. A teoria de Heckscher-Ohlin, apresentada nesta seção, representa uma das principais contribuições da teoria neoclássica para a teoria de comércio internacional. Ela difere do modelo ricardiano de vantagem comparativa, pois abandona a questão tecnológica da forma 
como foi utilizada pelo mesmo. A teoria de Heckscher-Ohlin considera, como causas das vantagens comparativas, as diferenças nas dotações de fatores e na intensidade em que eles são utilizados na produção dos bens. Isso implica diferença tecnológica entre os produtos, mas não entre os países, como supunha o modelo ricardiano.

Uma outra questão que difere os dois modelos encontra-se no fato de que, enquanto o modelo ricardiano considera apenas o trabalho como fator de produção, a teoria de Heckscher-Ohlin leva em consideração, além do trabalho, o capital como fator de produção.

De acordo com as teorias de comércio internacional vistas até o momento a diferença entre os países seria o único motivo que justificaria o comércio entre eles. Para Smith era a diferença no custo absoluto de produção; para Ricardo, a diferença nos custos relativos de produção ${ }^{15}$ e para a teoria de Heckscher-Ohlin a diferença dos países, no que diz respeito à sua dotação relativa de fatores. Como explicar, então, o comércio existente entre os países onde não há uma diferença tão grande com relação aos custos e há dotação semelhante de fatores? A próxima seção tem o objetivo de tratar essa questão.

\subsubsection{Comércio intra-indústria}

A teoria de Heckscher-Ohlin ajuda a explicar o comércio interindústria, ou seja, os fluxos de bens com intensidade de fatores distinta. Nesse caso, o país com uma grande oferta de mão-de-obra qualificada tende a exportar produtos com maior valor agregado e os que dispõem de maior volume de mão-de-obra de baixa qualificação tendem a exportar produtos menos elaborados. Já os países com um volume maior de terra e de recursos naturais tenderiam a exportar produtos agrícolas, ou que exigissem, na sua produção, um emprego maior de recursos naturais. A relação comercial interindústrial dá-se entre setores e atividades distintas.

\footnotetext{
${ }^{15}$ Cabe lembrar que os custos, para Smith e Ricardo, eram medidos em horas de trabalho empregadas na produção dos bens.
} 
A literatura sobre comércio internacional, na década de 80, contou com modelos que discutiam as implicações das economias de escala e da concorrência monopolística na teoria neoclássica de comércio internacional. Seus principais representantes foram Paul Krugman e Elhanan Helpman. De acordo com essa nova corrente teórica, o comércio pode ser justificado, mesmo quando o fluxo de bens apresenta intensidade de fatores semelhantes. Essa modalidade é denominada comércio intra-indústria, e consiste no comércio dentro de um mesmo setor industrial.

De acordo com Krugman \& Obstfeld (1999, p. 140), essa modalidade de comércio é justificada pela pressuposição de que a indústria de manufaturas não é uma indústria perfeitamente competitiva, que elabora produtos homogêneos. Com isso, têmse produtos substitutos próximos, mas não idênticos, elaborados por algumas poucas empresas de um mesmo ramo industrial, que podem ou não estar localizadas em países distintos. Segundo os autores, "Por causa das economias de escala, nenhum país consegue produzir toda a variedade de produtos manufaturados por si mesmo; então, apesar de ambos os países poderem produzir algumas manufaturas, eles estarão produzindo coisas diferentes".

Com relação à importância relativa do comércio intra-indústria e interindústria Krugman \& Obstfeld (1999) afirmam que ela vai depender de quão similares sejam os países. Quanto mais parecidos forem os países na dotação dos fatores, mais se espera que o comércio intra-indústria se dê com maior intensidade.

Os trabalhos empíricos sobre o comércio intra-indústria medem, em geral, o nível de comércio intra-indústria pelo índice sugerido por Grubel \& Lloyd (1975), citados por Hidalgo (1993):

$$
T=\frac{\sum_{i}^{n}\left(X_{i}+M_{i}\right)-\sum_{i}^{n}\left|X_{i}-M_{i}\right|}{\sum_{i}^{n}\left(X_{i}+M_{i}\right)} \cdot 100
$$

onde:

$\mathrm{X}_{\mathrm{i}}=$ valor ou volume exportado do produto $\mathrm{i}$; 
$\mathrm{M}_{\mathrm{i}}=$ valor ou volume importado do produto $\mathrm{i}$;

O resultado desse índice, de comércio intra-indústria, pode ser interpretado como se segue: se for igual a $0 \%$, o comércio é unilateral $\left(X_{i}=0\right.$ ou $\left.M_{i}=0\right)$, ou seja, todo o comércio é do tipo interindústria; se for igual a 100\%, o comércio é inteiramente intra-indústria $\left(\mathrm{X}_{\mathrm{i}}=\mathrm{M}_{\mathrm{i}}\right)$ e quando está no intervalo entre $0 \%$ e $100 \%$, pode ser classificado como comércio interindústria, quanto mais próximo de zero estiver, e como comércio intra-indústria quanto mais próximo de cem se encontrar. $\mathrm{O}$ critério de classificação adotado na análise será o seguinte: $\mathrm{T} \geq 50 \%$ comércio intra-indústria; $\mathrm{T}<$ $50 \%$ comércio interindústria.

O comércio intra-indústria não elimina a possibilidade de existência de comércio interindústria; na verdade, esses dois tipos de comércio são observados na economia mundial. No comércio interindústria, prevalece a teoria de Heckscher-Ohlin e a especialização da produção. $\mathrm{O}$ comércio, neste caso, estaria baseado na dotação de fatores em cada um dos países. Com isso, espera-se que um país abundante em capital seja um país exportador líquido de manufaturas e um importador líquido de alimentos e de recursos naturais.

Quanto ao comércio intra-indústria, a comercialização ocorre mesmo que a dotação de fatores seja semelhante entre dois países. A justificativa para a existência deste tipo de comércio baseia-se em dois fatos: as firmas produzirem produtos diferenciados e as economias de escala impedirem que os países produzam toda variedade de produtos existente. A localização da produção neste padrão de comércio fica indeterminada; a única afirmação que se pode fazer é que os países irão produzir bens e serviços que apresentam alguma diferença, o que leva à comercialização entre os mesmos.

Com a descrição do comércio intra-indústria, a evolução da teoria de comércio internacional, no que diz respeito à justificativa para que as nações comercializem entre si, é encerrada. A seção seguinte deste capítulo traz uma revisão dos estudos elaborados, que empregam a teoria de Heckscher-Ohlin. 


\subsection{Trabalhos empíricos desenvolvidos que testam a validade do teorema de Heckscher-Ohlin}

Nesta seção, são apresentados os principais trabalhos realizados com o objetivo de testar a validade do teorema de Heckscher-Ohlin e a descrição de alguns trabalhos que buscaram observar a relação existente entre emprego qualificado e não-qualificado e o comércio existente entre os diversos países.

Segundo a abordagem de Heckscher-Ohlin com relação ao comércio entre os países, um país com abundância relativa em capital, por exemplo, teria de se especializar na produção de bens que exijam maior intensidade de capital, exportando esses bens. Já a importação desse país deveria centrar-se em bens que exijam maior quantidade de trabalho para sua produção. Dessa forma, através do comércio, sua escassez de trabalho seria compensada.

O primeiro trabalho empírico cujos resultados permitiram conclusões acerca do comércio internacional, com base na teoria de Heckscher-Ohlin, foi o desenvolvido por Leontief (1953). Os resultados obtidos pelo autor ficaram conhecidos na literatura como Paradoxo de Leontief, por irem de encontro ao que era esperado, considerando o Teorema de Heckscher-Ohlin. Cabe ressaltar que o objetivo de Leontief não era testar o Teorema de Heckscher-Ohlin, mas sim o de fazer uma análise detalhada na estrutura básica das relações comerciais entre os Estados Unidos e o resto do mundo, com os dados disponíveis, como resultado da elaboração da matriz insumo-produto para este país, no ano de 1947.

Para atingir seu objetivo, Leontief fez uso da matriz insumo-produto, dando os primeiros passos nas técnicas de utilização desses dados. $\mathrm{O}$ resultado obtido por ele, que deu origem ao paradoxo de Leontief, foi a constatação de que os bens exportados pelos Estados Unidos eram mais intensivos em trabalho que os bens importados.

Para chegar aos resultados, o autor calculou as quantidades de capital e de trabalho necessárias à produção final de cada setor (requisitos diretos), mais as quantidades necessárias à produção de insumos para a produção final de cada setor e, 
ainda, as quantidades necessárias à produção de insumos para a produção de insumos, abrangendo toda a cadeia de produção (requisitos indiretos).

Leontief caracterizou a produção final como a produção de bens exportáveis e importáveis. Com base nessas duas informações, ele calculou, então, as necessidades médias de capital e de trabalho, dado o acréscimo de US\$ 1,0 milhão, tanto nas exportações quanto nas importações. Os resultados obtidos por Leontief encontram-se na Tabela 13.

Tabela 13. Necessidades domésticas de capital e de trabalho para a produção de US\$1,0 milhão de bens exportáveis e importáveis Norte-americanos (composição média de 1947).

\begin{tabular}{lcc}
\hline Insumos & Exportações & Importações \\
\hline Capital (US\$ de 1947) & 2.550 .780 & 3.091 .339 \\
Trabalho (homem/ano) & 182.313 & 170.004 \\
\hline
\end{tabular}

Fonte: Leontief (1953, p.522)

Com base nos resultados apresentados na Tabela 13, pode-se verificar que os bens importados eram relativamente mais intensivos na utilização de capital, enquanto os exportados, em trabalho. Para exportar US\$ 1,0 milhão, era necessária a utilização de US\$ 2.550.780 de capital, enquanto, para as importações, esse número era de US\$ 3.091.339. Em relação à utilização da mão-de-obra, para a produção de US\$ 1,0 milhão para a exportação, seria necessária a utilização de 182.313 homens/ano e, para produzir internamente os produtos importados, esse número seria de 170.004 homens/ano, portanto, menor que o necessário para a produção das exportações.

Em termos relativos, ou seja, verificando-se a razão entre o volume de capital e de trabalho empregado na produção das exportações e importações, utilizando como base os resultados obtidos na Tabela 13, pode-se verificar que há um volume maior de trabalho presente nas exportações, 14, em relação às importações, 18. 
Assim Leontief concluiu, com seus resultados, que não se poderia afirmar que os Estados Unidos exportavam bens relativamente abundantes em capital, em relação ao trabalho. A explicação de Leontief estaria vinculada ao fato de a “(...) produtividade do capital Norte americano por homem/ano ser bastante superior à de outros países, uma vez que detinha tecnologias de produção não disponíveis para o resto do mundo, além de formas de organização superior e melhor fonte de qualificação do trabalho, capazes de tornar o uso desse fator preferível ao capital” (Machado, 1997, p.34).

Uma das críticas que Leamer (1980) fez ao trabalho de Leontief, assim como a outros trabalhos realizados para verificar a intensidade da utilização dos fatores na produção dos bens a comercializar, diz respeito à necessidade de realização de testes, a priori, para verificar a abundância relativa dos fatores no país ou região em questão. Segundo ele, a constatação do paradoxo de Leontief foi feita apenas com base na hipótese de que os Estados Unidos teriam abundância relativa de capital.

Utilizando, como base, os resultados obtidos por Leontief e metodologia semelhante à descrita na seção 3.1.2.3 do presente trabalho, Leamer (1980) realizou o teste para verificar se os Estados Unidos apresentavam realmente abundância relativa de capital, como supunha Leontief. Como resultado, obteve uma relação capital/trabalho de 11.783 homens/ano para as exportações líquidas; para o consumo doméstico, essa relação foi de 6.737 homens/ano. Com base nesses resultados, Leamer (1980) constatou a abundância relativa de capital para os Estados Unidos.

Depois de obtidos esses resultados paradoxais, um grande número de novos estudos sobre o assunto foi desenvolvido, inclusive estudos do próprio Leontief. A questão da mão-de-obra passou a ser analisada mais detalhadamente, e outros fatores, como recursos naturais, foram excluídos, com objetivo de melhorar os resultados obtidos. Todas as iniciativas ocorreram no sentido de reduzir possíveis distorções dos modelos que utilizam como fatores de produção o capital e o trabalho.

Leontief (1956) procurou verificar a proporção dos fatores e a estrutura do comércio norte-americano. Os resultados, considerando a qualificação da mão-de-obra, estavam de acordo com o sperado, não contrariando o teorema de Heckscher-Ohlin, ou 
seja, as exportações norte-americanas eram relativamente mais intensivas em mão-deobra qualificada em relação às importações. Afirma, também, que a mão-de-obra norteamericana seria três vezes mais eficiente que a do resto do mundo, principalmente devido a diferenças organizacionais das empresas, o que explicaria os resultados paradoxais por ele obtidos em seu trabalho de 1953.

Com o objetivo de comparar os requisitos de mão-de-obra necessários à produção de bens exportáveis e importáveis para treze países, no ano de 1962, Keesing (1968) admitiu que as tecnologias de produção eram idênticas às da economia norteamericana. A classificação da mão-de-obra em especializada e menos especializada foi realizada segundo a qualificação requerida para o exercício das funções. Para atender a seu objetivo, o autor construiu um indicador de intensidade de capital humano, esse foi definido pela razão trabalho especializado/trabalho menos especializado, dando maior peso às categorias que exigem maior investimento em educação e treinamento.Verificou, então, qual a sua utilização na produção de uma unidade do valor de bens exportáveis e importáveis, para cada um dos treze países. Assim, o autor pôde verificar quais países tinham implícitas, em suas exportações e importações, a maior e a menor intensidade de mão-de-obra qualificada.

Como resultado, Keesing (1968) pôde verificar que o perfil de comércio entre os treze países sugeria que os exportadores de bens intensivos em trabalho qualificado seriam importadores de bens intensivos em mão-de-obra menos qualificada, e que os países exportadores de bens intensivos em mão-de-obra menos qualificada seriam importadores de bens que utilizam, em seu processo produtivo, maior volume de trabalho mais qualificado.

Os resultados obtidos por Keesing (1968), em parte, comprovam o teorema de Heckscher-Ohlin, pois o autor não determinou a abundância relativa dos fatores nos países, para que o teorema fosse comprovado em sua totalidade. $\mathrm{O}$ autor, em sua análise, também utilizou apenas os empregos diretos para a produção, pois a metodologia por ele adotada não the permitia verificar o volume de empregos indiretos, gerados na produção dos bens comercializados. 
Baldwin (1971), assim como Leontief, avaliou os requisitos diretos e indiretos necessários à produção. Tinha como objetivo avaliar os diversos fatores de produção, além do capital e do trabalho, como determinantes de padrões do comércio norteamericano, no ano de 1962. Os resultados dos testes da relação capital/trabalho, implícita nas exportações e importações, confirmam o paradoxo de Leontief, mesmo quando os setores ligados à agricultura e aos recursos naturais são separados. Os resultados somente deixaram de ser paradoxais quando se referiram exclusivamente à proxies de intensidade de capital humano (qualificação da mão-de-obra): verificou-se que o tempo médio de educação é maior na produção de bens exportáveis do que na produção de bens importáveis. O mesmo vale para as demais proxies por ele utilizadas: custo médio de educação, rendimento médio dos trabalhadores e proporção de engenheiros e cientistas ligados à produção.

Um dos primeiros trabalhos desenvolvidos para o Brasil, com o objetivo de testar as hipóteses implícitas no teorema de Heckscher-Ohlin, utilizando-se para tanto, a abordagem da especialização da mão-de-obra, foi o trabalho de Rocca (1970), citado por Rocca \& Barros(1972). Em seu trabalho, o autor pôde verificar que o Brasil importa, em maior proporção, produtos com alto coeficiente de qualificação de mão-de-obra. Já em suas exportações, predominam os produtos que exigem em menor proporção esse tipo de trabalho. Cabe ressaltar que Rocca (1970) utilizou os índices de qualificação para os setores, obtidos por Keesing (1968), para a economia norte-americana.

Utilizando os mesmos índices obtidos por Keesing (1968), Tyler (1972) testa as hipóteses descritas a seguir para a economia brasileira:

a) As importações de produtos manufaturados utilizam trabalho especializado mais intensivamente do que as exportações. No cálculo, realizado por Tyler (1972) do índice ponderado de utilização intensiva de trabalho especializado para as importações e exportações, Tyler encontrou os seguintes resultados, 8,87 e 7,85, respectivamente, o que confirma sua hipótese;

b) As importações de manufaturados utilizam trabalho especializado mais intensivamente do que a dos países industriais mais desenvolvidos. Essa hipótese 
também é confirmada por Tyler (1972, p. 140), quando se observa que o índice obtido para o Brasil $(0,663)$ é inferior apenas ao índice obtido para o Japão;

c) As exportações de manufaturados no Brasil utilizam menos intensivamente trabalho especializado em relação aos países industrializados, mais desenvolvidos. Essa hipótese não é confirmada, o que segundo Tyler (1972, p. 144) significa que o "desenvolvimento dos recursos humanos no Brasil é inconsistente, com a utilização intensiva de trabalho especializado observada, incorporada nas exportações de seus produtos manufaturados";

d) As importações líquidas para indústrias diferentes estão correlacionadas positivamente com as respectivas necessidades de trabalho especializado. Tyler (1972) verifica um bom ajustamento entre as importações líquidas industriais e a especialização do trabalho, através da análise de regressão;

e) A pauta de importação de manufaturados está correlacionada positivamente com as respectivas necessidades de trabalho especializado. Através da análise de regressão, Tyler (1972) constata a validade dessa hipótese por ele levantada;

f) A pauta de exportação de manufaturados no Brasil está correlacionada negativamente com a necessidade de trabalho especializado da indústria. Essa hipótese, assim como a "c", não é constatada por Tyler, que ressalta que "a composição das exportações do Brasil apresenta uma utilização intensiva de trabalho especializado, semelhante à dos países altamente desenvolvidos, classificando-se entre França e Áustria” (Tyler, 7972, p. 141) e

g) A exportação de manufaturas do Brasil para membros da Associação Latino-Americana de Livre Comércio (ALALC) e para todos os países menos desenvolvidos, utiliza mais intensivamente trabalho especializado do que suas exportações industriais para os países desenvolvidos. Tyler (1972) utiliza essa hipótese, que é por ele constatada por meio de análise de regressão, para explicar, em parte, os resultados obtidos por ele nas hipóteses "c" e "f". 
Segundo Tyler, a explicação para a não constatação das hipóteses "c" e "f" encontra-se relacionada ao destino das exportações de produtos manufaturados do Brasil. Como grande parte das exportações brasileiras eram destinadas, em 1968, para países menos desenvolvidos, embora no Brasil haja falta de trabalho especializado frente aos países desenvolvidos, o autor alega que a posição do país “(...) frente a frente com os países da ALALC e outros países menos desenvolvidos, pode ser oposta devido ao amplo moderno e altamente diversificado setor industrial brasileiro" (Tyler, 1972, p. 145).

Outras possíveis explicações levantadas por Tyler, para justificar os resultados por ele obtidos, foram: o fenômeno da disparidade regional de renda no Brasil; a participação de recursos naturais, pois, segundo ele, o Brasil obtém vantagens comparativas em várias de suas exportações de manufaturados, devido às disponibilidades de recursos naturais, como é o caso de alguns produtos químicos; a eficiência relativa entre as indústrias brasileiras e as distorções no mercado de fatores, ocorrendo esta última em decorrência dos incentivos para a industrialização, via processo de substituição de importações. $\mathrm{O}$ autor conclui que a experiência brasileira não é inconsistente com os pressupostos do teorema de Heckscher-Ohlin, desde que as considerações feitas por ele sejam levadas em conta.

Tyler (1972, p.151) também sugere que o “(...) crescimento das exportações poderia ser aumentado, se a composição das exportações de produtos manufaturados brasileiros mudar-se para uma composição mais consistente com as vantagens comparativas internacionais do Brasil". Assim, o autor parece sugerir que o comércio deveria adaptar-se ao que se esperaria no pressuposto do teorema de Heckscher-Ohlin.

Muitas vezes, a teoria não é capaz de explicar alguns fatos da realidade, o que na verdade, não a invalida, pois podem existir outros fatores que não são considerados nessa teoria e que fazem com que ela não seja válida para alguns casos. Acredita-se que a justificativa para o resultado obtido por Tyler pode estar relacionada à base de dados por ele utilizada. A crítica comum que se faz em relação aos dois primeiros trabalhos diz respeito à utilização de informações sobre a economia norte-americana, para determinar 
a necessidade de trabalho especializado no comércio estabelecido entre o Brasil e os demais países. Esses dados podem gerar algumas informações distorcidas para a economia brasileira.

Rocca \& Barros(1972) buscaram, em seu trabalho, verificar se, com base na utilização de indicadores nacionais de qualificação, a pauta de exportações brasileiras está em conformidade com a estrutura de vantagem comparativa observada no país. Admitem a hipótese de que o capital humano qualificado é um elemento escasso no Brasil.

Os autores fazem algumas criticas a metodologia adotada por Tyler (1972), bem como revêem algumas de suas conclusões. Segundo os mesmos, Tyler não poderia utilizar seus dados para comparações internacionais “(...) os índices de qualificação calculados para a economia americana, embora possam ser utilizados como indicadores no sentido de comparar o conteúdo de mão-de-obra qualificada contida nas importações e exportações brasileiras, dificilmente poderiam ser utilizados para o estabelecimento de comparações internacionais" (Rocca \& Barros, 1972, p.91). A utilização desses coeficientes de conteúdo de qualificação, obtidos para vários ramos da indústria norteamericana na indústria ou nas exportações brasileiras, de acordo com Rocca \& Barros (1972, p.92), “(...) deve conduzir a erros maiores que os derivados do uso dessa metodologia para os países europeus de desenvolvimento relativo mais elevado".

Rocca \& Barros (1972) ressaltam que a aplicação dos índices de qualificação, obtidos para a economia norte-americana às exportações brasileiras resulta na superestimação do coeficiente calculado, o que, em parte, justifica os resultados obtidos por Tyler, em que as exportações brasileiras apresentaram coeficientes de qualificação mais elevados, se comparados aos obtidos para países considerados desenvolvidos.

Em seu trabalho, Rocca \& Barros (1972) utilizaram os dados disponíveis para o estado de São Paulo, a partir dos quais construíram indicadores para o Brasil. Segundo os autores, a utilização desses dados “(...) não invalida os resultados, dada a importância relativa da produção e da exportação de produtos industriais paulistas no total do país" (Rocca \& Barros, 1972, p.93). Em função de não haver as informações disponíveis para 
o Brasil como um todo, acredita-se que os dados de São Paulo conduzam a uma aproximação maior da realidade brasileira, em relação às constatações da economia norte-americana obtidas por Keesing (1968) e utilizadas por Tyler (1972).

Para estimar o coeficiente médio de trabalho qualificado presente no comércio exterior brasileiro, os autores consideraram, para as exportações, os indicadores nacionais e, para as importações, os coeficientes calculados para a economia norteamericana. Para verificar o coeficiente de qualificação associado a cada fluxo de comércio, considerando 18 setores, foi calculada uma média ponderada, onde os pesos foram as participações do setor nas importações e exportações. Com base nesse critério, os valores obtidos foram os seguintes: importações 1,013 e exportações 0,353. Com base nesse resultado, Rocca \& Barros (1972, p.99) concluem que “(...) a quantidade de trabalho qualificado incorporado às importações é consideravelmente superior àquelas calculadas para as exportações brasileiras”.

Os autores criticam o trabalho Tyler (1972) no seguinte aspecto “(...) ao contrário do que propuseram alguns analistas, não existe evidências de que o Brasil seja exportador de produtos intensivos em qualificação da mão-de-obra, relativamente a outros países desenvolvidos. (...) a pauta de exportações industriais do país parece refletir a utilização mais intensiva do fator mais abundante, qual seja, o trabalho nãoqualificado" (Rocca e Barros, 1972, p.107).

Rocca \& Barros contestam também a hipótese levantada por Tyler (1972) de que as exportações brasileiras de manufaturados, para a ALALC e outros países menos desenvolvidos utilizariam mais intensivamente $\mathrm{o}$ trabalho especializado, quando comparadas às exportações industriais para países desenvolvidos. Quando se compara o resultado, obtido pelos autores, dos coeficientes médios de qualificação presentes nas exportações brasileiras para os Estados Unidos, 0,318, e para a ALALC, 0,361, “(...) de fato, não se observam grandes diferenças no conteúdo de trabalho qualificado" (Rocca e Barros, 1972, p.108).

Os resultados obtidos pelos autores encontram-se em conformidade com o teorema de Heckscher-Ohlin, levando em consideração sua hipótese inicial de que o 
capital humano qualificado era um elemento escasso no Brasil, no final da década de sessenta. Cabe ressaltar, entretanto, que o teste da validade desse teorema não foi objetivo do trabalho desenvolvido pelos autores.

As questões comuns que se levantam com relação aos trabalhos apresentados são o fato de eles levarem em consideração apenas às indústrias de manufaturados. Além disso, a metodologia neles utilizada não permitiu o dimensionamento da utilização de trabalho especializado ou não nos requisitos indiretos de mão-de-obra, necessários à produção. Com isso não se pretende tirar o mérito dos trabalhos desenvolvidos por esses autores, pois se trata dos primeiros trabalhos desenvolvidos com o objetivo de verificar a utilização de mão-de-obra especializada na produção brasileira de bens comercializados com outros países.

Machado (1997) propõe-se a avaliar o padrão de comércio externo brasileiro, em 1980, do ponto de vista da mão-de-obra empregada na produção de bens exportáveis e importáveis. Para tanto, utilizou a fundamentação da Teoria de Heckscher-Ohlin, considerando a qualificação da mão-de-obra.

A classificação da mão-de-obra, feita por Machado (1997), obedeceu ao seguinte critério:

- como mão-de-obra qualificada foi considerada a categoria pessoal de nível superior;

- como mão-de-obra de menor qualificação foi considerado o restante do pessoal ocupado, com exceção dos gerentes, chefes e supervisores, pois tais categorias incluem, segundo o autor, tanto o pessoal de nível superior como o de nível médio e até mesmo aquele com menor grau de educação formal.

Os dados referentes à produção, aos coeficientes de requisitos diretos e indiretos e as informações sobre o comércio do Brasil com o resto do mundo foram obtidos junto àmatriz insumo -produto de 1980 do Brasil, publicada pelo IBGE.

Os requisitos diretos de mão-de-obra por classificação - qualificada (I) e menos qualificada (II) - foram calculados com base na seguinte equação em formato matricial: 


$$
\mathbf{R}=\overline{\mathbf{Q}}^{-1} \cdot \mathbf{L}
$$

Onde: $\mathbf{R}$ são os coeficientes de utilização de mão-de-obra, necessários à produção de

Cr\$ 1 milhão de 1980; $\overline{\mathbf{Q}}^{-1}$ é a inversa diagonal do vetor que contém a produção total por atividade e $\mathbf{L}$ é a matriz com a quantidade de trabalhadores, por qualificação, utilizada na produção de cada um dos setores.

Para o cálculo dos requisitos diretos e indiretos de produção de cada atividade necessária à produção de Cr\$ 1 milhão de bens exportáveis e importáveis, Machado (1997) utilizou a seguinte equação:

$$
\mathbf{q}=(\mathbf{I}-\mathbf{A})^{-1} \cdot \mathbf{e}
$$

onde q é a matriz que mostra o total produzido por setor de atividade, dado o aumento de uma unidade monetária na demanda por exportáveis, importáveis e consumo doméstico final e, ainda, dado o aumento de uma unidade monetária no saldo da balança comercial ou nas exportações líquidas; I é uma matriz identidade; A é uma matriz de coeficientes técnicos; e e é uma matriz que representa a demanda por exportáveis, importáveis, consumo doméstico final e exportações líquidas.

Machado (1997) inclui o consumo doméstico final e as exportações líquidas porque essas variáveis o auxiliam na interpretação dos resultados finais, gerados pela matriz q. Essas variáveis estão presentes no modelo Heckscher-Ohlin-Vanek e são utilizadas para verificar a abundância relativa de fatores, tendo o comércio como referencial, mesmo nos casos em que o país tenha abundância relativa em ambos os fatores $^{16}$.

Para calcular o índice de conteúdo médio de mão-de-obra qualificada, presente na produção de Cr\$ 1 milhão de demanda final, utiliza a seguinte expressão:

$$
\mathbf{F}=\mathbf{R}^{\prime} \cdot \mathbf{q}
$$

onde cada elemento de $\mathbf{F}$ representa o conteúdo total (direto e indireto) médio de cada tipo de qualificação de mão-de-obra.

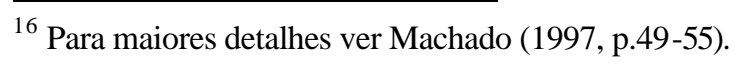


Como resultado, Machado (1997) pôde verificar que o Brasil era importador líquido de mão-de-obra de nível superior e exportador líquido do restante da mão-deobra, confirmando, assim, a sua hipótese inicial de que o país é relativamente abundante em mão-de-obra de menor qualificação e relativamente escasso em mão-de-obra de nível superior.

Machado (1997, p. 79) conclui que seus resultados "não são paradoxais, isto é, estão de acordo com a teoria: o Brasil, em 1980, exportou bens intensivos em seu recurso relativamente abundante e importou bens intensivos em seu recurso escasso".

Considerando a forma mais tradicional de verificação do teorema de Heckscher-Ohlin, ou seja, comparando o índice de conteúdo médio de mão-de-obra qualificada implícito nas exportações $(0,0044)$ e nas importações $(0,0084)$, Machado (1997) verificou para o Brasil, em 1980, que o conteúdo médio de mão-de-obra qualificada estava mais presente nas importações que nas exportações brasileiras.

O trabalho desenvolvido por Machado (1977) é satisfatório, no que diz respeito ao teste do Teorema da Heckscher-Ohlin, pois verificou a dotação relativa dos fatores, bem como considerou os efeitos diretos e indiretos na produção, através da utilização do modelo insumo-produto.

Maia (2001) teve como objetivo separar os impactos sentidos no mercado de trabalho, no Brasil, devido à abertura comercial; á mudança tecnológica e ao aumento na demanda final. Os impactos foram avaliados tendo como base os anos de 1985 e 1995, e considerando o grau de qualificação da mão-de-obra. A autora, também, buscou verificar se o teorema de Heckscher-Ohlin foi corroborado, após a liberalização comercial.

A metodologia que a autora utilizou foi definida com base na pesquisa que Greenhalgh et al (1998) fizeram, para analisar a mudança na estrutura de demanda por mão-de-obra no Reino Unido.

Para o cálculo da produção, Maia (2001) utilizou os dados das matrizes insumoproduto do Brasil dos anos de 1985 e 1995. A qualificação da mão-de-obra foi obtida 
com base nos microdados da PNAD, a partir dos quais a autora calculou a proporção de emprego por escolaridade e por setor; em seguida, aplicou essa proporção aos dados de emprego presentes nas matrizes.

Para classificar a qualificação da mão-de-obra, Maia (2001) utilizou os seguintes critérios:

- $\quad$ Considerou mão-de-obra qualificada as pessoas ocupadas que tinham mais de 11 anos de estudo e como mão-de-obra não qualificada as pessoas sem escolaridade e com, no máximo, 11 anos de estudo e

- Considerou, em um segundo momento, mão-de-obra qualificada as pessoas ocupadas que tinham 9 anos ou mais de estudo e como mão-de-obra não qualificada as pessoas sem escolaridade e com, no máximo, 8 anos de estudo, ou seja, o ensino fundamental completo.

Como resultado da aplicação do modelo, Maia (2001, p.60) observou que o impacto total no emprego foi positivo, ampliando-se o número de empregos qualificados em $40,6 \%$ e não-qualificado em $11,8 \%{ }^{17}$. Tal resultado deve-se basicamente à variação no consumo, pois foi a única variável que possibilitou a geração de novos postos de trabalho para ambos os níveis de qualificação, no período.

As mudanças no emprego, atribuídas à liberalização comercial, foram negativas para ambos os níveis de qualificação da mão-de-obra. Com relação às mudanças tecnológicas, a autora verificou que estas implicaram redução na utilização da mão-deobra não qualificada e aumento na quantidade de empregos qualificados. $\mathrm{O}$ efeito total do impacto das mudanças tecnológicas implicou redução maior do número de pessoas ocupadas do que a observada no comércio externo.

\footnotetext{
${ }^{17}$ Vale lembrar, que no mercado de trabalho brasileiro, a maior parcela do pessoal ocupado é composta pela mão-de-obra não qualificada. Os resultados apresentados dizem respeito à variação no emprego dentro de cada classificação, e mostram que a utilização da mão-de-obra com maior qualificação cresceu mais em relação à não qualificada, mas ainda não a excedeu em valor. Considerando os valores absolutos apresentados por Maia (2001), verifica-se que o número de empregos qualificados aumentou em 1,5 milhão e o não-qualificado em 6 milhões.
} 
A análise setorial dos impactos sobre o mercado de trabalho mostrou, segundo Maia (2001, p.65), “(...) que os setores que absorveram relativamente mais mão-de-obra qualificada, foram aqueles em que a produtividade do trabalho gerou relativamente mais empregos; na maioria intensivos em trabalho. Por outro lado, os setores que mais eliminaram emprego com a liberalização comercial foram, na maioria, os intensivos em capital (...)".

Os resultados de Maia (2001) confirmam o teorema de Heckscher-Ohlin, ou seja, nos anos de 1985 e 1995, antes e após a liberalização, as exportações brasileiras se apresentam-se como intensivas em mão-de-obra menos qualificada, e as importações, caso fossem produzidas internamente, seriam intensivas em mão-de-obra qualificada, e esse resultado é compatível com a dotação relativa dos fatores. Como o Brasil é relativamente mais abundante em mão-de-obra não qualificada, deve especializar-se na produção e na comercialização de produtos intensivos na utilização desse fator.

A autora ressalta que, apesar de confirmada a teoria de Heckscher-Ohlin, os resultados obtidos indicam que utilização da mão-de-obra qualificada nas exportações cresceu mais em relação à utilização da mão-de-obra não qualificada, passando de $0,04^{18}$ em 1985 para 0,05 em 1995, enquanto, para as importações, essa relação não foi alterada, mantendo-se em 0,08 em ambos os anos.

Considerando-se o segundo critério de classificação da qualificação da mão-deobra, adotado pela autora, e ampliando-se o número de trabalhadores qualificados com a redução do número de anos de escolaridade, de 11 anos ou mais para 9 anos ou mais, pode-se verificar que os resultados deste critério, menos exigente, também indicam o aumento na intensidade da utilização da mão-de-obra qualificada nas exportações brasileiras. A principal diferença que Maia (2001) observou, quando comparou os resultados dos dois critérios, foi a maior quantidade nas exportações brasileiras, em 1995, da mão-de-obra qualificada, chegando, inclusive, a superar a quantidade que seria utilizada para substituir as importações no primeiro critério.

\footnotetext{
${ }^{18}$ Esse resultado foi obtido dividindo-se o número de pessoas qualificadas pelo número de pessoas não qualificadas, utilizadas para produzir bens exportáveis em 1985. A mesma metodologia foi adotada para o ano de 1995 e para as importações.
} 
Maia (2001, p.73) conclui que “(...) houve relativa mudança na estrutura do emprego, em favor do trabalho qualificado, motivado pela liberalização comercial e pela mudança tecnológica". Já o consumo final teve grande importância na geração de novos postos de trabalho, principalmente aqueles não-qualificados.

Em relação à conclusão da autora sobre o período, cabe fazer a seguinte consideração: os dados das matrizes são relativos ao ano em questão e, como conseqüência, os resultados obtidos possibilitam apenas conclusões sobre os anos específicos, 1985 e 1995, e uma suposição de que reflete o período entre eles.

Considerando a abertura comercial, a autora concluiu que ela foi a principal causadora dos ganhos de produtividade, pois, com a liberalização comercial, novas tecnologias puderam ser adquiridas.

Para analisar as características do fluxo comercial brasileiro, tanto em suas relações com o Mercosul quanto em relação ao resto do mundo, Vascocelos (2001) observou as intensidades fatoriais presentes nos fluxos de comércio. Os fatores de produção considerados pelo autor foram capital e trabalho. Como trabalho, o autor considerou o volume total de homens, por ano, para cada setor de atividade da matriz insumo-produto. Para dimensionar o fator de produção capital, Vasconcelos (2001) considerou o resíduo entre a diferença do valor adicionado e a remuneração ao fator trabalho (gastos com salários, encargos sociais e outras remunerações), também presentes na matriz insumo produto, como a remuneração do fator capital. De acordo com o autor, "Conceitualmente, este resíduo é o excedente operacional bruto, que, por sua vez, pode ser considerado como uma proxy para a remuneração do capital físico." (Vasconcelos, 2001, p.623).

Para mensurar as intensidades fatoriais do fluxo de comércio Brasil-Mercosul, o autor utilizou a abordagem tradicional de Leontief, que relaciona o emprego dos fatores presentes, tanto nas exportações quanto nas importações. No fluxo de comércio brasileiro com relação ao resto do mundo, o autor utilizou o modelo Heckscher-OhlinVanek, assim como Machado (1997). O que difere, basicamente, nos dois modelos utilizados por Vasconcelos (2001) é que, no caso do segundo modelo, a dotação relativa 
dos fatores é caracterizada, e não apenas uma hipótese, como no modelo de Leontief. Para tanto, as informações sobre exportações líquidas e sobre o consumo doméstico foram incluídas no segundo caso.

Nas análises realizadas para o fluxo comercial entre o Brasil e o Mercosul Vasconcelos (2001) considerou três anos: 1982, 1990 e 1996. Assim, o autor pretendia verificar se a implementação do acordo de comércio entre os países alterou o padrão de comércio observado entre os mesmos. $\mathrm{O}$ autor constatou que, para os três anos em questão, as exportações brasileiras com destino ao Mercosul mostraram-se mais capital intensivas em relação às importações. Vasconcelos considerou a hipótese, mas não a testou, de que o Brasil seria relativamente abundante em capital e relativamente escasso em trabalho, em relação aos demais países que compõem o Mercosul. Com isso, o autor concluiu que, no caso do comércio Brasil-Mercosul, o teorema de Heckscher-Ohlin pode ser considerado como válido, para os três anos em questão. Assim, Vasconcelos (2001) destaca que a implementação do Mercosul não alterou o padrão de comércio preexistente.

Considerando a análise que Vasconcelos (2001) fez do fluxo de comércio brasileiro com o resto do mundo, para os anos de 1990 e 1996, o autor pôde constatar que, para os dois anos em questão o comércio internacional revela que o fator trabalho apresentou-se como o mais abundante, relativamente ao capital. Verificou também a validade do teorema de Heckscher-Ohlin, pois as exportações se mostraram mais trabalho intensivas em relação às importações.

Vasconcelos (2001, p.639) também concluiu que os testes por ele realizados parecem confirmar a seguinte colocação: “(...) a direção do comércio pode afetar o padrão de comércio, ou seja, segundo Havrylyshn (1987), as exportações de países em desenvolvimento com destino aos países também em desenvolvimento são mais intensivas em capital do que as exportações com destino aos países industrializados. Já as importações dos países em desenvolvimento provenientes de países em desenvolvimento tendem a ser menos intensivas em capital do que as importações provenientes de países desenvolvidos". 
Cabe destacar que os testes realizados por Vasconcelos (2001) não podem confirmar a afirmação acima exposta. $\mathrm{O}$ mesmo não verificou a dotação de fatores no fluxo de comércio estabelecido entre o Brasil e o Mercosul, apenas supôs que o Brasil seria relativamente abundante em capital, em relação os demais países que compõem esse acordo comercial. Com relação ao resto do mundo, cabe observar que, nesta agregação se encontram os países desenvolvidos e em desenvolvimento; por isso, fica comprometida a implícita hipótese do autor de que esse agregado representaria os países desenvolvidos.

Utilizando dois modelos, um de equilíbrio geral e outro de insumo-produto, Leon et al. (2000) examinaram o impacto do aumento das exportações dos setores tradables sobre o emprego setorial e qualificado brasileiro, e verificaram quais setores detêm posição estratégica na geração de empregos. Foram analisados dez setores e seis níveis de qualificação da mão-de-obra, estes com base na escolaridade. A fonte dos dados do mercado de trabalho foi a PNAD e os dados referentes ao comércio e aoproduto doméstico foram extraídos da matriz insumo-produto.

Como resultado, Leon et al (2000) verificaram que, no ano de 1996, a indústria de transformação teve grande importância na estrutura econômica, o que se refletiu em grande impacto indireto sobre o emprego. Com a desagregação da ocupação da mão-deobra em níveis educacionais, verificaram que, com a expansão das exportações na indústria de transformação, na agropecuária e nos serviços auxiliares, o emprego da mão-de-obra menos qualificada foi favorecido. Já o setor de prestação de serviços favoreceu mais o trabalho qualificado. Nos demais setores da economia, a expansão do emprego foi mais homogênea entre os níveis educacionais. $\mathrm{O}$ objetivo dos autores não foi testar a validade do teorema de Heckscher-Ohlin, mas mostraram em seu trabalho os setores exportadores que apresentavam maior possibilidade de gerar empregos qualificados e não qualificados.

Nesse capítulo, observou-se o desenvolvimento das teorias de comércio internacional que tinham como objetivo verificar os motivos que levariam os países a comercializar. Em maiores detalhes, foram apresentadas as teorias que serão testadas no 
presente trabalho: Heckscher-Ohlin e comércio intra-indústria. Foram, também, apresentados alguns trabalhos desenvolvidos com o objetivo de testar a validade do teorema de Heckscher-Ohlin para alguns países, e outros que buscaram avaliar a relação existente entre comércio externo e emprego de mão-de-obra por qualificação. O próximo capítulo tem como objetivos: apresentar os modelos insumo-produto nacional e regional; apresentar a metodologia empregada para testar o teorema de Heckscher-Ohlin para os comércios externo e interno e mostrar as fontes dos dados utilizados, bem como os tratamentos necessários aos dados. 


\section{METODOLOGIA E FONTE DOS DADOS}

O presente capítulo tem como objetivos: descrever a metodologia adotada no trabalho para a construção das matrizes insumo-produto nacional e inter-regional; demonstrar a metodologia utilizada para testar a validade do teorema de HeckscherOhlin e apresentar as fontes e o tratamento dos dados utilizados.

\subsection{Metodologia dos modelos insumo-produto nacional e regional}

Uma das principais metas deste trabalho é testar a validade do teorema de Heckscher-Ohlin, para o comércio estabelecido internamente entre as cinco macrorregiões brasileiras e para o comércio com os principais parceiros comerciais do Brasil e de suas regiões, no mercado mundial. Para tanto, um modelo inter-regional para as regiões e um nacional para o Brasil foram utilizados. Nesta seção, apresenta-se uma revisão dos modelos insumo-produto nacional e regional, encontrados na literatura.

\subsubsection{Modelo insumo-produto nacional}

Wassily Leontief, no final da década de 30, para analisar os grandes agregados econômicos, desenvolveu o modelo insumo-produto, implementando empiricamente o sistema de equilíbrio geral, desenvolvido por Walras. De acordo com Guilhoto (2001, p.11), 
"O que Leontief conseguiu realizar foi a construção de uma 'fotografia' da própria economia; nessa fotografia, ele mostrou como os setores estão relacionados entre si (...) o resultado foi uma visão única e compreensiva de como a economia funciona como cada setor se torna mais ou menos dependente dos outros"

A utilização desse modelo possibilita verificar as consequiências que uma mudança em determinado setor da economia acarreta em outros setores, oque permite, dentre outras aplicações, a sua utilização no planejamento, tanto macro quanto microeconômico, de acordo com Montoya (1998).

A tabela insumo-produto descreve os fluxos de bens e serviços entre todos os setores de uma economia, durante certo período de tempo, normalmente um ano. De acordo com Miller e Blair (1985), a compra e a venda de mercadorias entre os setores são realizadas em unidades físicas, mas devido aos problemas de mensuração e a situações quando um setor vende mais de um bem ou serviço, geralmente a contabilidade é realizada em termos monetários.

A Figura 14 mostra, de forma esquemática, as relações fundamentais do modelo insumo-produto. Na demanda intermediária, são apresentadas as compras e vendas entre os setores na economia, que podem estar interligados direta ou indiretamente ${ }^{19}$. A demanda final pode ser destinada ao consumo das famílias, à formação de capital, às demandas do governo e outros ou à exportação. No processo produtivo fazem-se necessários, além da aquisição dos insumos, o pagamento dos impostos, a importação de alguns produtos em determinados setores, a geração de valor adicionado e empregos.

Os setores na economia não são auto-suficientes, necessitam adquirir insumos produzidos por outros setores. Considerando um setor qualquer, no caso o setor $\mathrm{j}$, nas colunas da tabela insumo-produto pode-se verificar as compras de insumos intermediários produzidos pelo próprio setor e por todos os outros setores, que são utilizadas para a produção no setor j. Além da aquisição de insumos intermediários, o

\footnotetext{
${ }^{19}$ A ligação direta entre os setores ocorre quando um setor adquire insumos diretamente de outro setor. Já a indireta assemelha-se ao efeito multiplicador descrito por Keynes, e ocorre quando a demanda por um determinado insumo estimula a produção, não só do setor que produz esse insumo, mas também dos demais setores que fornecem produtos para que esse insumo possa, então, ser produzido.
} 
setor $\mathrm{j}$ deve, também, pagar impostos ao governo, remunerar o capital, a terra e o trabalho. Caso algum dos insumos utilizados pelo setor $\mathrm{j}$ não seja produzido internamente, e seja necessário importá-lo, essa aquisição é, então, registrada na linha correspondente da tabela insumo-produto.

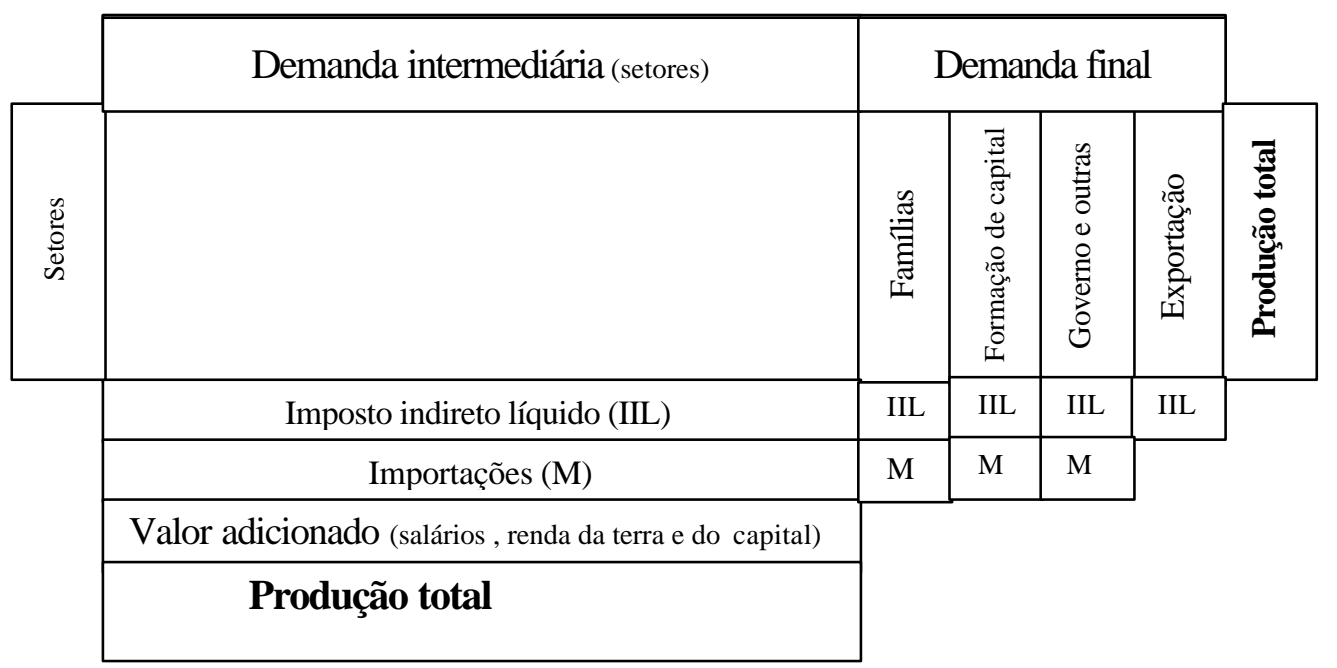

Figura 14 - Relações fundamentais de insumo produto.

Fonte: Adaptado de Guilhoto (2001)

Considerando uma economia composta por $\mathrm{n}$ setores, a soma total da coluna do setor $\mathrm{j}$ pode ser expressa da seguinte forma:

$$
X_{j}=\sum_{i=1}^{n} X_{i j}+T_{j}+V_{j}+M_{j} \quad \quad \mathrm{i}=1,2, \ldots \mathrm{n}
$$

onde:

$\mathrm{X}_{\mathrm{j}}$ : valor da produção total do setor $\mathrm{j}$;

$\mathrm{X}_{\mathrm{ij}}$ : fluxo monetário correspondente às compras de insumos do setor $\mathrm{j}$ junto ao setor $\mathrm{i}$;

$\mathrm{T}_{\mathrm{j}}$ : total dos tributos indiretos líquidos recolhidos pelo setor $\mathrm{j}$;

$\mathrm{V}_{\mathrm{j}}$ : total do valor adicionado gerado pelo setor $\mathrm{j}$; 
$\mathrm{M}_{\mathrm{j}}$ : importação do setor $\mathrm{j}$.

Nas linhas da tabela insumo-produto, encontram-se registrados os fluxos de saída da produção. Eles mostram a distribuição da produção de um setor produtivo entre os demais setores da economia (demanda intermediária), ou para os diversos componentes da demanda final. Tomando como base uma linha na tabela insumoproduto que represente, por exemplo, o setor i, o produto bruto desse setor pode ser escrito da seguinte forma:

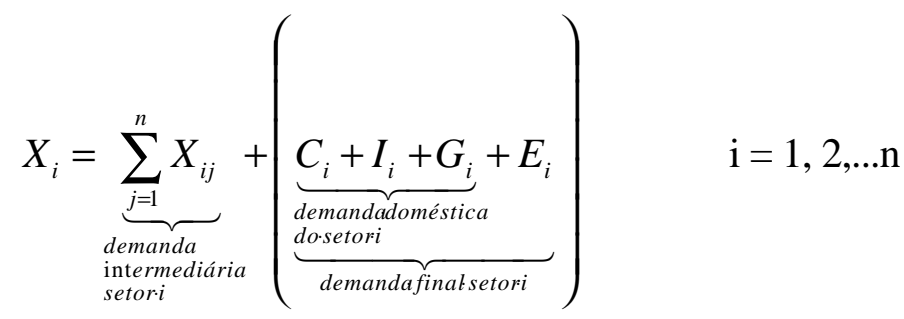

onde:

$\mathrm{X}_{\mathrm{i}}$ : valor da produção total do setor i (demanda final e intermediária);

$\mathrm{X}_{\mathrm{ij}}$ : fluxo monetário da produção do setor $\mathrm{i}$, utilizada como insumo intermediário pelo setor $\mathrm{j}$;

$\mathrm{C}_{\mathrm{i}}$ : produção do setor i comprada pelas famílias;

$\mathrm{I}_{\mathrm{i}}$ : produção do setor i destinada ao investimento;

$\mathrm{G}_{\mathrm{i}}$ : produção do setor i adquirida pelo governo ou por outras demandas;

$\mathrm{E}_{\mathrm{i}}$ : produção do setor i destinada à exportação.

Admitindo que os fluxos intermediários, por unidade de produto final, são fixos, pode-se derivar o sistema aberto de Leontief ${ }^{20}$ :

$$
X_{i}=\sum_{j=1}^{n} a_{i j} X_{j}+Y_{i} \quad \mathrm{i}=1,2, \ldots \mathrm{n}
$$

\footnotetext{
${ }^{20}$ Considera-se sistema aberto de Leontief, quando a demanda final é exógena ao sistema, e fechado quando essa é considerada endógena. Neste último caso, a renda paga às famílias retorna ao sistema em forma de consumo e este, por sua vez, leva ao aumento na produção, na renda, no consumo, etc.
} 
onde

$Y_{i}$ : componentes da demanda final: famílias, investimento, exportação e governo e outras demandas;

$\mathrm{a}_{\mathrm{ij}}$ : coeficiente técnico ou direto de insumo, indica a quantidade de insumo do setor $\mathrm{i}$ necessária para obter uma unidade do produto do setor $\mathrm{j}$, sendo $0 \leq a_{i j}<1$. É obtido admitindo que parcela do insumo $\mathrm{i}$ requerida pelo setor $\mathrm{j}$ seja diretamente proporcional à produção do setor j. $X_{i j}=a_{i j} X_{j} \cdot o u \cdot a_{i j}=\frac{X_{i j}}{X_{j}}$. A matriz A é constituída a partir do conjunto dos coeficientes $\mathrm{a}_{\mathrm{ij}}$, e tem dimensão ( $\mathrm{n} \times \mathrm{n}$ ). Em cada coluna dessa matriz encontra-se descrita a estrutura tecnológica do setor correspondente.

A equação (17) pode ser representada na forma matricial:

$$
X=\mathbf{A} X+Y
$$

Onde $X$ e $Y$ são vetores coluna de ordem (n x 1), que representam a produção total e a demanda final por setor, respectivamente. Isolando $X$ na equação (18), obtém-se a produção total necessária para atender a demanda final:

$$
X=(I-\mathbf{A})^{-1} Y
$$

onde: $(\mathbf{I}-\mathbf{A})^{-1}$ é a matriz de coeficientes técnicos de insumos diretos e indiretos, conhecida como a matriz inversa de Leontief. Considerando $\mathbf{B}=(\mathbf{I}-\mathbf{A})^{-1}$, cada elemento $b_{i j}$ da matriz inversa de Leontief quantifica os requisitos diretos e indiretos da produção total do setor $\mathrm{i}$, necessários para produzir uma unidade da demanda final do setor $\mathrm{j}$.

Com relação à estimativa das matrizes A e B, Miller e Blair (1985) ressaltam que, quando ela é feita a partir de fluxos monetários, os valores dos coeficientes técnicos podem ser afetados, devido a problemas de mudança de preços relativos. Para contornar essa questão, o que se tem feito usualmente é assumir que os preços relativos são constantes. Mesmo considerando essa questão, Guilhoto (2001, p.18) afirma que "a análise de insumo-produto se constitui uma ferramenta poderosa, talvez a melhor 
disponível, quando é necessário o desenvolvimento de um estudo multissetorial da economia".

A estrutura básica de um modelo insumo-produto nacional foi apresentada nesta seção, onde apenas uma matriz é construída para representar a economia como um todo. Quando o objetivo é verificar o comportamento de regiões que fazem parte dessa economia, é necessário que o modelo nacional seja, então, desagregado. Questão que será tratada na próxima seção.

\subsubsection{Modelos de insumo-produto regional, inter-regionais e intra-regionais}

Uma matriz regional, na maioria das vezes, tem a mesma estrutura de uma matriz nacional, apenas discriminando o que é exportação (importação) para as outras regiões do país e o que é exportação (importação) para outros países.

Miller e Blair (1985) destacam duas questões importantes, em relação à economia regional que influenciam os modelos regionais. A primeira diz que, apesar de as informações de uma matriz insumo-produto nacional serem uma espécie de "média" dos dados de produtores individuais, localizados nas regiões da nação, a estrutura de produção em uma região particular pode ser idêntica, ou pode diferir muito daquela apresentada na matriz nacional. $\mathrm{O}$ segundo ponto para que os autores chamam atenção diz respeito ao tamanho da área econômica ou, no caso, de uma determinada região. Ressaltam que, quanto menor for a região, mais dependente é sua economia do comércio com o exterior, tanto para a venda de produtos regionais, quanto para as compras de insumos necessários à produção.

Os estudos regionais requerem, para a construção de suas matrizes, um maior número de informações desagregadas. Devido à dificuldade em obter informações dos fluxos inter-regionais, bem como ao alto custo de levantamento delas, foram desenvolvidos alguns métodos de construção para esses modelos. Um deles, com informações censitárias, é considerado o método ideal, pois a construção das matrizes se dá a partir das informações observadas. Há outros sem informações censitárias, em que 
os modelos são construídos a partir de hipóteses e de estimativas das informações diretas requeridas.

Os métodos, com e sem informações censitárias, não são mutuamente excludentes. Roundt (1983) reconhece que, na prática, todas as matrizes insumo-produto são matrizes híbridas, construídas por meio de técnicas com informações semicensitárias, pois empregam dados primários e secundários, em uma extensão maior ou menor, dependendo do objetivo e das informações disponíveis.

$\mathrm{Na}$ Figura 15, são apresentadas algumas metodologias de construção das matrizes inter-regionais, considerando a natureza dos dados e as técnicas utilizadas para estimar os coeficientes interindústriais. Considerando a origem dos dados, pôde-se observar dois métodos: censitário e com informações censitárias limitadas. No método com informação censitária, recomenda-se a utilização de informações observadas na construção das matrizes. No que se refere aos métodos com informação censitária limitada, os principais encontram-se abaixo descritos.

1- Método do quociente locacional: este método consiste em comparar a participação percentual da mercadoria de uma região em um setor particular, com a participação percentual da mesma mercadoria regional e com o total da produção de bens nacionais. De acordo com Miller e Blair (1985), o quociente locacional simples para o setor i na região $\mathrm{F}, L Q_{i}^{F}$, pode ser definido como:

$$
L Q_{i}^{F}=\frac{X_{i}^{F} / X^{F}}{X_{i}^{N} / X^{N}}
$$

onde: $X_{i}^{F}$ e $X_{i}^{N}$ representam os totais da produção do setor i regional e nacional, respectivamente e $X^{F}$ e $X^{N}$ denotam o total da produção regional e nacional, respectivamente. $\mathrm{O}$ valor do quociente indica que há importação do produto, quando for menor do que 1, que há exportação, quando for maior do que 1 e auto-suficiência, quando for igual a 1. Haddad (1989) chama a atenção para a utilidade do coeficiente 
locacional em uma fase exploratória dos estudos regionais, e coloca que eles devem ser utilizados em conjunto com outras informações sobre as regiões estudadas.

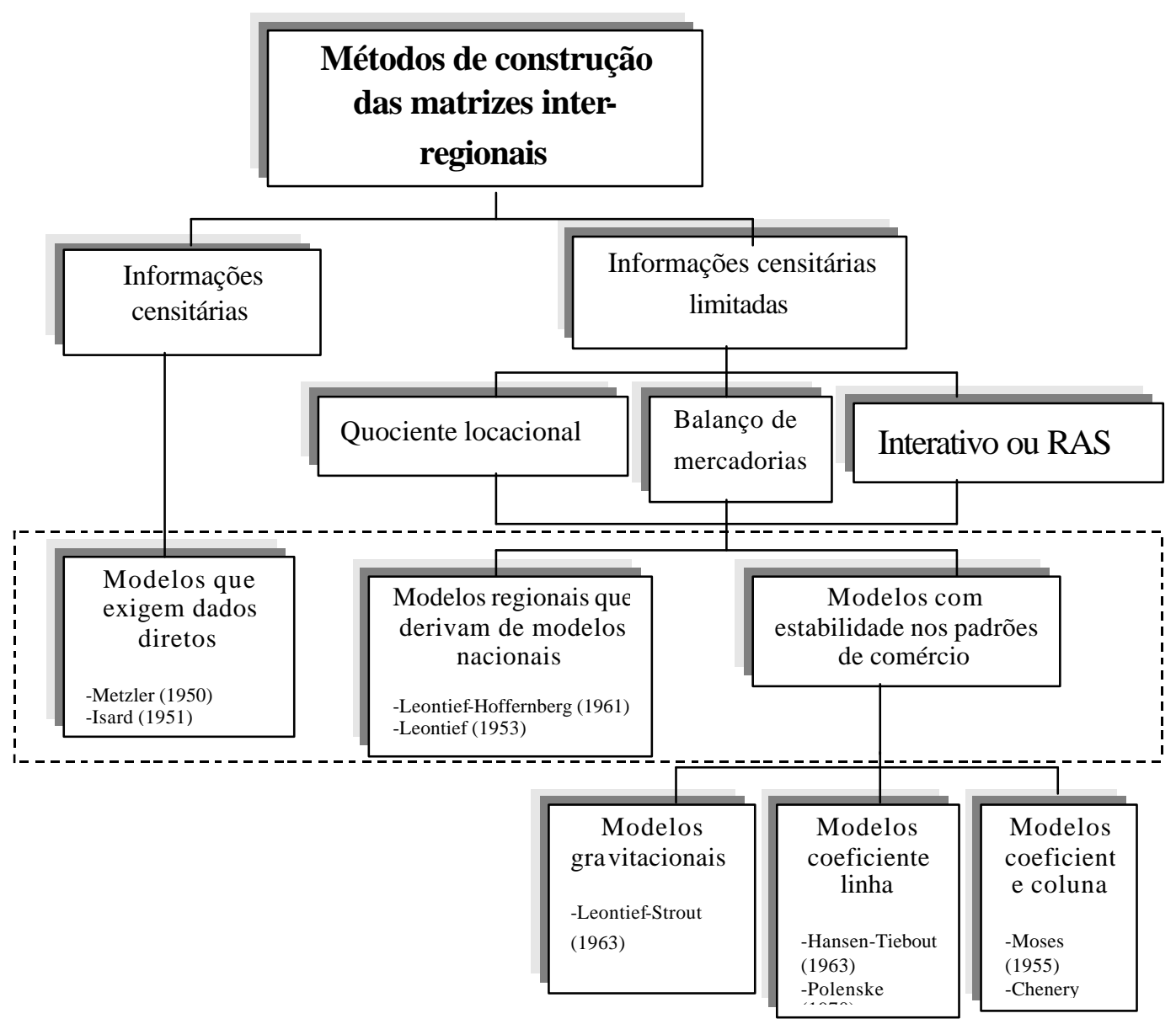

Figura 15 - Classificação dos métodos e modelos insumo-produto inter-regionais.

Fonte: Adaptado de Montoya (1998)

2- Método do balanço de mercadorias ${ }^{21}$ : este método, de acordo com Miller e Blair (1985), foi utilizado nos primeiros estudos que trabalharam com modelos regionais de insumo-produto. Os dados regionais são obtidos, utilizando-se um percentual da oferta

\footnotetext{
${ }^{21}$ Para maiores detalhes ver Miller e Blair (1985, p.46-52)
} 
regional que determina o quanto da demanda total (final + intermediária) do produto de cada setor é atendida pela produção interna. Tal método apresenta duas limitações: considera que todos os setores que demandam, por exemplo, produtos da agropecuária compram um percentual fixo estimado da própria região e o restante, importam das demais regiões; considera que a técnica de produção regional é idêntica à técnica nacional, pois a matriz A é mantida com valores originais.

3- Método interativo ou RAS: é utilizado para ajustar matrizes tanto em sua dimensão temporal quanto espacial. É um método que vem sendo bastante utilizado para ajustar as matrizes regionais, a partir de informações agregadas. Miller e Blair (1985) apresentam, em detalhes, a formulação e a aplicação desse método. Alguns trabalhos utilizaram-no juntamente com o de coeficientes locacionais para estimar matrizes regionais, como, por exemplo, Crocomo (1998), Silveira (2000) e Parré (2000).

De acordo com Cavalcanti (1994) e Bom (1984), os modelos inter-regionais podem, ainda, ser classificados em três grupos diferentes, dependendo do enfoque ou da maneira de calcular os coeficientes técnicos, como pode ser observado na Figura 15:

1. Modelos que sugerem a utilização de dados diretos na construção de matrizes insumo-produto para cada região, além de uma matriz dos fluxos interregionais;

2. Modelos nos quais os totais regionais derivam do modelo insumo-produto nacional. Eles também são denominados intranacionais;

3. Modelos que assumem uma certa estabilidade nos padrões de comércio inter-regional, representando uma simplificação do modelo de Isard (1951). Esse grupo pode ser classificado em outros três subgrupos, dependendo das proporções delimitadas para comprar ou vender.

- Modelos gravitacionais: consideram que as exportações de uma mercadoria i, da região $\mathrm{F}$ para a região $\mathrm{M}$, são diretamente proporcionais à produção total da região de origem e do seu consumo na região de destino, e inversamente proporcionais à distância entre as duas regiões. De acordo com Cavalcanti (1994), esse modelo é adequado à 
situação de alteração nos padrões de comércio inter-regional, ocorridos devido a alterações na produção, no consumo e no custo de transferência entre regiões;

- Modelos de coeficientes linha: distribuem a produção regional entre mercado doméstico e exportação para as demais regiões. A principal característica do modelo é considerar que a proporção do produto vendido por uma região permanece constante, independente do nível de demanda das outras regiões;

- Modelos de coeficientes coluna: sua apresentação é bastante similar à do coeficiente linha. É estabelecida a hipótese simplificadora que as importações de um setor $\mathrm{i}$, na região $\mathrm{F}$, serão distribuídas através dos setores da região $\mathrm{F}$, da mesma forma que o produto do setor i é produzido na região. Dessa forma, cada região importa uma proporção fixa de suas necessidades de um produto, de uma região específica, e cada setor segue o mesmo padrão da região como um todo.

Uma revisão de alguns modelos insumo-produto regionais, que utilizaram os métodos acima descritos, é apresentada na próxima seção.

\subsubsection{Revisão dos modelos insumo -produto regionais ${ }^{22}$}

Na Figura 16, é apresentada a estrutura de classificação dos modelos insumoproduto regionais. Considerando o número de regiões envolvidas, os modelos podem ser divididos em modelos para uma região e para várias regiões.

No modelo para uma única região, o país ou região é dividido em duas partes: uma relativa à região alvo e a outra que corresponde ao resto da economia. O objetivo, neste caso, é quantificar os impactos que uma variação na demanda final por bens produzidos na região de interesse teria sobre os setores nela localizados, dentre outros objetivos. A limitação desse tipo de modelo é que eles não permitem captar nenhum tipo de ligação entre as diversas regiões do país.

\footnotetext{
${ }^{22}$ O desenvolvimento desta seção está baseado em Montoya (1998) e Moretto (2000).
} 
Os modelos para várias regiões são utilizados para analisar simultaneamente várias regiões de um mesmo país, estado ou blocos de países. Permitem estudar os fluxos inter-regionais e intra-regionais de produção. Dois métodos são utilizados para obter as informações necessárias: os censitários e os com informação censitária limitada. Os modelos mais representativos na literatura, que utilizam o método de informação censitária, são: Metzler (1950) e Isard (1951) e encontram-se abaixo descritos.

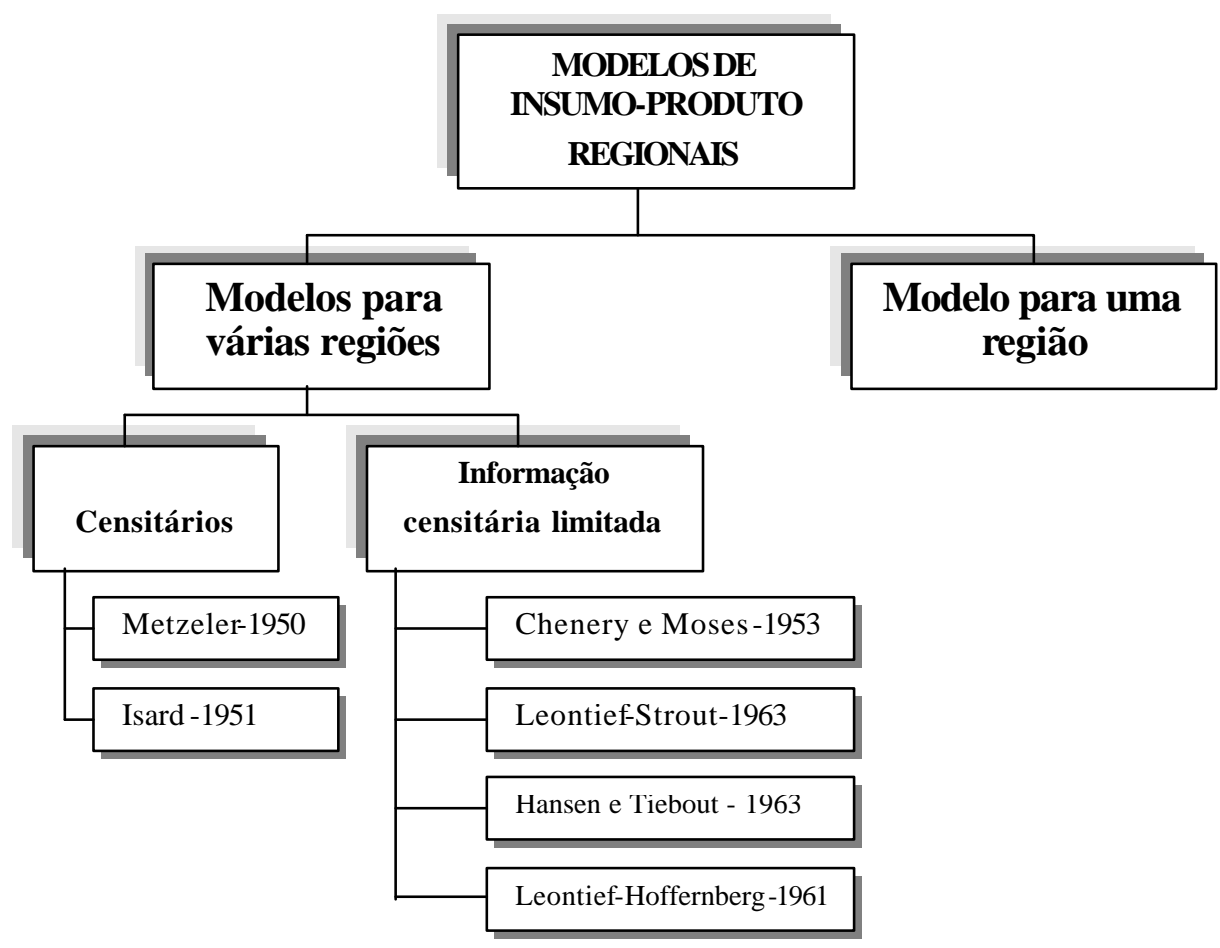

Figura 16 - Classificação dos modelos insumo-produto regionais.

Fonte: Elaborada com base nas classificações feitas por Montoya (1998) e Moretto (2000)

O modelo de Metzler (1950) deu origem aos modelos inter-regionais. Foi utilizado com o objetivo de analisar os impactos dos efeitos de transbordamento interregional, em função de uma variação autônoma da demanda final em uma dada região, e as conseqüentes propagações nos fluxos comerciais entre as regiões. A limitação desse 
modelo encontra-se no fato de ser um modelo agregado que não discrimina os efeitos inter-regionais, por setor produtivo de cada região.

O modelo de Isard (1951) é considerado como o ideal na literatura. Requer a construção de uma matriz de coeficientes técnicos, para cada uma das regiões, além da formulação de uma matriz de comércio inter-regional, em que o produto é apresentado desagregado por setor e por região de origem e destino. O objetivo do autor é respeitar as desigualdades geográficas e a heterogeneidade das áreas de mercado existentes, pois considera que uma mesma mercadoria pode ser produzida de forma diferente nas regiões. A limitação empírica desse modelo é a dificuldade de obter as informações necessárias.

Os modelos apresentados abaixo são considerados, de acordo com a Figura 16, como modelos com informação censitária limitada.

Com relação aos modelos de Chenery ${ }^{23}$, citado por Montoya (1998), e Moses (1955), cabe ressaltar que o objetivo de Chenery era analisar os impactos que os investimentos em larga escala, no Sul da Itália, poderiam ter sobre a produção e a renda dentro da própria região e no restante do país. Moses (1955) tinha como objetivo analisar empiricamente a estabilidade dos coeficientes de abastecimento inter-regional, tendo sido aplicado para 3 regiões dos EUA. A hipótese do modelo é que cada região importa uma proporção fixa de suas necessidades de uma determinada mercadoria de uma região específica e que cada setor segue o mesmo padrão de importação da região como um todo. A limitação do modelo é que a estrutura de abastecimento intra e interregional é desconhecida, pois para cada mercadoria produzida, desconhece-se quanto de seus insumos são produzidos na região e quanto deles são produzidos em outras regiões. Esse modelo é um exemplo de aplicação do modelo de coeficiente coluna.

O modelo de Leontief-Strout é um exemplo de aplicação do modelo gravitacional. Pressupõe que as exportações de uma mercadoria de uma região a outra são diretamente proporcionais à sua produção total na região de origem e ao seu

\footnotetext{
23 CHENERY, H. Regional analysis. In: CHENERY, H.; CAO-PINA. The structure and growth of
} Italian economy. Rome: U.S. Mutual Security Agency, 1953. 
consumo total na região de destino, e são inversamente proporcionais à distância entre as duas regiões. As vantagens do modelo é que exige poucas informações estatísticas e a operacionalização computacional é simples, além de permitir a existência de comércio simultâneo de uma mesma mercadoria entre duas regiões.

O modelo de Hansen e Tiebout (1963), também denominado de coeficiente de linha, é definido segundo seus coeficientes técnicos. A proporção do produto vendido pelas diversas regiões é a mesma, independente do nível de demanda das regiões compradoras. A sua limitação pode ser observada na crítica de Richardsom² ${ }^{24}$ (1972), citado por Montoya (1998, p.59), "essa é uma suposição inaceitável, pois infringe o pressuposto Walrasiano dos modelos de insumo-produto, segundo o qual variações no produto são causadas por mudanças na demanda e por variações nos preços por mudanças na oferta".

O Modelo de Leontief-Hoffernberg é derivado de uma matriz insumo-produto nacional. Objetiva calcular, por meio de etapas sucessivas, a quantidade de cada uma das mercadorias regionais e nacionais que deverá ser produzida em cada região, sendo dados os valores da demanda final. A vantagem na utilização desse modelo repousa na reduzida necessidade de informações. A limitação está associada ao padrão de comércio produzido pelo modelo, que não permite identificar as origens das importações ou os destinos das exportações.

Alguns estudos foram realizados para o Brasil, objetivando, dentre outras coisas, a construção de matrizes inter-regionais. De acordo com Crocomo (1998), o Banco de Desenvolvimento de Minas Gerais (BDMG) e o Centro de Desenvolvimento e Planejamento Regional (CEDEPLAR) construíram alguns quadros de insumo-produto para Minas Gerais para os anos de 1953, 1968, 1959 e 1970. Duas outras experiências foram realizadas e resultaram na construção das matrizes para os anos de 1980 e 1985: uma para a região Norte, publicada em 1994 pela SUDAM, e outra para a região Nordeste, publicada em 1992 pelo BNB. Crocomo (1998) construiu um modelo com as

\footnotetext{
${ }^{24}$ RICHSRDSON, H. Input-output and regional economics. London: Ed. Weidenfeld and Nicolson, 1972.
} 
matrizes insumo-produto para as cinco macrorregiões brasileiras, para o ano de 1985. O objetivo foi fazer uma análise das relações inter-regionais e intersetoriais na economia brasileira. Parré (2000) construiu as matrizes para os anos de 1990 e 1995, com base nas estimativas iniciais de Crocomo (1998), buscando verificar a importância e a evolução do agronegócio nas macrorregiões brasileiras no período. Silveira (2000) construiu um modelo inter-regional para os estados que compõem a bacia do São Francisco, para o ano de 1995, e analisou as relações interindústriais, a capacidade de indução das demandas finais ao crescimento e as relações de comércio entre esses estados. Associou, à tradicional matriz de insumos, uma matriz considerando o recurso água e, a partir desta, estimou os coeficientes de uso da água e calculou os multiplicadores. Moretto (2000) desenvolveu um modelo inter-regional para estudar a economia paranaense no ano de 1995. Rodrigues (2000) construiu matrizes insumo-produto para o Paraná, para os anos de 1980, 85, 90 e 95. Silva (2001) construiu um modelo para São Paulo, Minas Gerais e para o resto do Brasil, para o ano de 1996, com o objetivo principal de comparar as estruturas econômicas e verificar a questão da guerra fiscal entre os estados. Guilhoto et al., op. cit. (2003) construíram para o ano de 1999 um modelo inter-regional, considerando as cinco macrorregiões do Brasil. Nesse modelo foram considerados 141 produtos e 90 setores, e foi o modelo utilizado no presente trabalho. Esses e outros trabalhos realizados buscaram, em principio, construir matrizes mais próximas possível do modelo proposto por Isard (1951).

Nesta seção foram apresentados os modelos utilizados para a construção de matrizes regionais encontrados na literatura, além das experiências brasileiras. A próxima seção tem como objetivo apresentar a estrutura básica do modelo utilizado no presente trabalho. 


\subsubsection{Estrutura básica de um modelo inter-regional para duas regiões ${ }^{25}$}

O objetivo desta seção é descrever um modelo inter-regional baseado no referencial teórico do modelo de Isard, o qual foi empregado na construção das matrizes utilizadas neste trabalho. Considerando uma economia hipotética com duas regiões ${ }^{26}, \mathrm{~F}$ e M, com 3 e 2 setores, respectivamente, temos, na Figura 17, um esquema do fluxo interregional de bens e serviços.

Dois fluxos podem ser observados na Figura 17:

- $\quad$ o intra-regional: realizado dentro da própria região;

$z_{i j}^{F F}$ : fluxo monetário do setor i para o setor $\mathrm{j}$ na região $\mathrm{F}$;

$z_{i j}^{M M}$ : fluxo monetário do setor i para o setor $\mathrm{j}$ na região $\mathrm{M}$;

$Y_{j}^{F F}$ : fluxo monetário do setor j para os componentes da demanda final da região $\mathrm{F}$;

$Y_{j}^{M M}$ :fluxo monetário do setor j para os componentes da demanda final da região $\mathrm{M}$.

- $\quad$ e o inter-regional: realizado entre as regiões.

$z_{i j}^{F M}$ : fluxo monetário do setor i da região $\mathrm{F}$ para o setor j na região $\mathrm{M}$;

$z_{i j}^{M F}$ : fluxo monetário do setor i da região $\mathrm{M}$ para o setor $\mathrm{j}$ na região $\mathrm{F}$;

$Y_{j}^{F M}$ : fluxo monetário do setor $\mathrm{j}$ da região $\mathrm{F}$ para os componentes da demanda final da região M;

$Y_{j}^{M F}$ : fluxo monetário do setor $\mathrm{j}$ da região $\mathrm{M}$ para os componentes da demanda final da região $\mathrm{F}$.

Os demais componentes da Figura 17 encontram-se abaixo descritos:

$X_{j}^{F}$ : o valor da produção total do setor j na região $\mathrm{F}$;

\footnotetext{
${ }^{25}$ O desenvolvimento desta seção bas eia-se em Miller e Blair (1985)

${ }^{26}$ Pode ser estendido para qualquer número de regiões.
} 
$X_{j}^{M}$ : valor da produção total do setor j na região $\mathrm{M}$;

$I_{i}^{F}$ : importações realizadas para a demanda intermediária do setor i na região $\mathrm{F}$;

$I_{i}^{M}$ : importações realizadas para a demanda intermediária do setor i na região M;

$I_{d}^{F}$ : importação destinada a $\mathrm{Y}^{27}$ na região $\mathrm{F}$;

$I_{d}^{M}:$ importação destinada a $\mathrm{Y}$ na região $\mathrm{M}$;

$I L L_{i}^{F}$ : impostos líquidos recolhidos pelo setor i na região $\mathrm{F}$;

$I L L_{i}^{M}$ : impostos líquidos recolhidos pelo setor i na região $\mathrm{M}$;

$I L L_{d}^{F}$ : impostos líquidos recolhidos por d, componentes da demanda final, na região $\mathrm{F}$;

$I L L_{d}^{M}$ : impostos líquidos recolhidos por d, componentes da demanda final, na região $\mathrm{M}$;

$V A_{i}^{F}$ : valor adicionado gerado pelo setor i na região $\mathrm{F}$;

$V A_{i}^{M}$ : valor adicionado gerado pelo setor i na região $\mathbf{M}$;

Tomando como base o setor 1 da região $\mathrm{F}$, o valor da produção total desse setor, $X_{1}^{F}$, pode ser expresso por:

$$
X_{1}^{F}=z_{11}^{F F}+z_{12}^{F F}+z_{13}^{F F}+z_{11}^{F M}+z_{12}^{F M}+Y_{1}^{F}
$$

onde $Y_{1}^{F}$ representa todos os componentes da demanda final pelo produto do setor 1 na região $F$.

Equações similares a 21 poderão ser construídas para os demais setores nas economias Fe M $\left(X_{2}^{F}, X_{3}^{F}, X_{1}^{M}, X_{2}^{M}\right)$.

Os coeficientes de insumo regionais, também, podem ser divididos em intra e inter-regionais.

\footnotetext{
${ }^{27}$ Onde Y representa os componentes da demanda final - consumo das famílias, investimentos, consumo do governo e exportações.
} 
- Coeficientes intra-regionais: $a_{i j}^{F F}$ e $a_{i j}^{M M}$ podem ser determinados como se segue:

1. $\quad a_{i j}^{F F}=\frac{z_{i j}^{F F}}{X_{j}^{F}} \Rightarrow z_{i j}^{F F}=a_{i j}^{F F} \cdot X_{j}^{F}$, ou na forma matricial,

$$
\mathbf{A}^{F F}=\mathbf{Z}^{F F}\left(\hat{X}^{F}\right)^{-1}
$$

onde $\mathbf{A}^{F F}$ é uma matriz que contém todos os coeficientes intra-regionais para a região $\mathrm{F}$; $\mathbf{Z}^{F F}$ é uma matriz que contém todos os fluxos monetários setoriais da região $\mathrm{F} ;\left(\hat{X}^{F}\right)^{-1}$ é o vetor que contém informações sobre a produção total, por setor, na região $F$ na diagonal e invertido.

2. $a_{i j}^{M M}=\frac{z_{i j}^{M M}}{X_{j}^{M}} \Rightarrow z_{i j}^{M M}=a_{i j}^{M M} \cdot X_{j}^{M}$, ou na forma matricial,

$$
\mathbf{A}^{M M}=\mathbf{Z}^{M M}\left(\hat{X}^{M}\right)^{-1}
$$

onde $\mathbf{A}^{M M}$ é uma matriz que contém todos os coeficientes intra-regionais para a região $\mathrm{M}$; $\mathbf{Z}^{M M}$ é uma matriz que contém todos os fluxos monetários setoriais da região $\mathbf{M}$; $\left(\hat{X}^{M}\right)^{-1}$ é o vetor que contém informações sobre a produção total, por setor, na região $\mathrm{M}$ na diagonal e invertido.

- $\quad$ Coeficientes inter-regionais: podem ser determinados de forma similar.

1. $\quad a_{i j}^{F M}=\frac{z_{i j}^{F M}}{X_{j}^{M}} \Rightarrow z_{i j}^{F M}=a_{i j}^{F M} \cdot X_{j}^{M}$, ou na forma matricial,

$$
\mathbf{A}^{F M}=\mathbf{Z}^{F M}\left(\hat{X}^{M}\right)^{-1}
$$




\begin{tabular}{|c|c|c|c|c|c|c|c|c|c|c|c|c|c|c|}
\hline \multirow{3}{*}{ Setores } & \multicolumn{5}{|c|}{ | DEMANDA INTERMEDIÁRIA } & \multicolumn{8}{|c|}{ DEMANDA FINAL } & \multirow{3}{*}{$\begin{array}{l}\text { PROD. } \\
\text { TOTAL }\end{array}$} \\
\hline & \multicolumn{3}{|c|}{ Região F } & \multicolumn{2}{|c|}{ Região M } & \multicolumn{4}{|c|}{ Região F } & \multicolumn{4}{|c|}{ Região M } & \\
\hline & 1 & 2 & 3 & 1 & 2 & $\mathrm{C}$ & $\mathrm{I}$ & $\mathrm{G}$ & E & $\mathrm{C}$ & $\mathrm{I}$ & $\mathrm{G}$ & $\mathrm{E}$ & \\
\hline \multirow{3}{*}{ 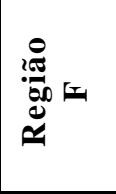 } & $Z_{11}^{F F}$ & $Z_{12}^{F F}$ & $Z_{13}^{F F}$ & $Z_{11}^{F M}$ & $Z_{12}^{F M}$ & $Y_{1}^{F F}$ & $Y_{1}^{F F}$ & $Y_{1}^{F F}$ & $Y_{1}^{F F}$ & $Y_{1}^{F M}$ & $Y_{1}^{F M}$ & $Y_{1}^{F M}$ & $Y_{1}^{F M}$ & $X_{1}^{F}$ \\
\hline & $Z_{21}^{F F}$ & $Z_{22}^{F F}$ & $Z_{23}^{F F}$ & $Z_{21}^{F M}$ & $Z_{22}^{F M}$ & $Y_{2}^{F F}$ & $Y_{2}^{F F}$ & $Y_{2}^{F F}$ & $Y_{2}^{F F}$ & $Y_{2}^{F M}$ & $Y_{2}^{F M}$ & $Y_{2}^{F M}$ & $Y_{2}^{F M}$ & $X_{2}^{F}$ \\
\hline & $Z_{31}^{F F}$ & $Z_{32}^{F F}$ & $Z_{33}^{F F}$ & $Z_{31}^{F M}$ & $Z_{32}^{F M}$ & $Y_{3}^{F F}$ & $Y_{3}^{F F}$ & $Y_{3}^{F F}$ & $Y_{3}^{F F}$ & $Y_{3}^{F M}$ & $Y_{3}^{F M}$ & $Y_{3}^{F M}$ & $Y_{3}^{F M}$ & $X_{3}^{F}$ \\
\hline \multirow{2}{*}{ 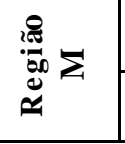 } & $Z_{11}^{M F}$ & $Z_{12}^{M F}$ & $Z_{13}^{M F}$ & $Z_{11}^{M M}$ & $Z_{12}^{M M}$ & $Y_{1}^{M F}$ & $Y_{1}^{M F}$ & $Y_{1}^{M F}$ & $Y_{1}^{M F}$ & $Y_{1}^{M M}$ & $Y_{1}^{M M}$ & $Y_{1}^{M M}$ & $Y_{1}^{M M}$ & $X_{1}^{M}$ \\
\hline & $Z_{21}^{M F}$ & $Z_{22}^{M F}$ & $Z_{23}^{M F}$ & $Z_{21}^{M M}$ & $Z_{22}^{M M}$ & $Y_{2}^{M F}$ & $Y_{2}^{M F}$ & $Y_{2}^{M F}$ & $Y_{2}^{M F}$ & $Y_{2}^{M M}$ & $Y_{2}^{M M}$ & $Y_{2}^{M M}$ & $Y_{2}^{M M}$ & $X_{2}^{M}$ \\
\hline Importação & $I_{1}^{F}$ & $I_{2}^{F}$ & $I_{3}^{F}$ & $I_{1}^{M}$ & $I_{2}^{M}$ & $I_{C}^{F}$ & $I_{I}^{F}$ & $I_{G}^{F}$ & & $I_{C}^{M}$ & $I_{I}^{M}$ & $I_{G}^{M}$ & & \\
\hline $\begin{array}{c}\text { Impostos } \\
\text { líquidos }\end{array}$ & $I L L_{1}^{F}$ & $I L L_{2}^{F}$ & $I L L_{3}^{F}$ & $I L L_{1}^{M}$ & $I L L_{2}^{M}$ & $I L L_{C}^{F}$ & $I L L_{I}^{F}$ & $I L L_{G}^{F}$ & $I L L_{E}^{F}$ & $I L L_{C}^{M}$ & $I L L_{I}^{M}$ & $I L L_{G}^{M}$ & $I L L_{E}^{M}$ & \\
\hline $\begin{array}{c}\text { Valor } \\
\text { adicionado }\end{array}$ & $V A_{1}^{F}$ & $V A_{2}^{F}$ & $V A_{3}^{F}$ & $V A_{1}^{M}$ & $V A_{2}^{M}$ & & & & & & & & & \\
\hline $\begin{array}{c}\text { Insumo } \\
\text { Total }\end{array}$ & $X_{1}^{F}$ & $X_{2}^{F}$ & $X_{3}^{F}$ & $X_{1}^{M}$ & $X_{2}^{M}$ & & & & & & & & & \\
\hline
\end{tabular}

Figura 17 - Fluxo interssetorial e inter-regional de bens e serviços para duas regiões.

Fonte: Adaptado de Miller e Blair (1985, p.55) 
onde $\mathbf{A}^{F M}$ é a matriz de coeficientes inter-regionais; $\mathbf{Z}^{F M}$ é a matriz com nformações sobre os fluxos monetários dos setores da região $\mathrm{F}$ para os setores da região $\mathrm{M}$; $\left(\hat{X}^{M}\right)^{-1}$ vetor na diagonal e invertido do valor da produção total, por setor, na região M.

2. $\quad a_{i j}^{M F}=\frac{z_{i j}^{M F}}{X_{j}^{F}} \Rightarrow z_{i j}^{M F}=a_{i j}^{M F} \cdot X_{j}^{F}$, ou na forma matricial,

$$
\mathbf{A}^{M F}=\mathbf{Z}^{M F}\left(\hat{X}^{F}\right)^{-1}
$$

onde $\quad \mathbf{A}^{M F}$ é a matriz de coeficientes inter-regionais; $\mathbf{Z}^{M F}$ é a matriz com informações sobre os fluxos monetários dos setores da região $\mathrm{M}$ para os setores da região $\mathrm{F}$; $\left(\hat{X}^{F}\right)^{-1}$ vetor na diagonal e invertido do valor da produção total, por setor, na região $\mathrm{F}$.

Para esse caso hipotético de duas regiões, quatro matrizes de coeficientes devem ser obtidas. No caso da região $\mathrm{F}$, que tem três setores, a matriz $\mathbf{A}^{\mathrm{FF}}$ é dada por:

$$
\mathbf{A}^{F F}=\left[\begin{array}{lll}
a_{11}^{F F} & a_{12}^{F F} & a_{13}^{F F} \\
a_{21}^{F F} & a_{22}^{F F} & a_{23}^{F F} \\
a_{31}^{F F} & a_{32}^{F F} & a_{33}^{F F}
\end{array}\right]
$$

As demais matrizes, com os coeficientes inter e intra-regionais, podem ser construídas de forma similar. Em relação à região $\mathrm{M}$, como ela tem apenas dois setores, a matriz $\mathbf{A}^{\mathrm{MM}}$ tem dimensão (2x2). Já as matrizes de coeficientes inter-regionais $\mathbf{A}^{\mathrm{FM}} \mathrm{e}$ $\mathbf{A}^{\mathrm{MF}}$ têm dimensões $(3 \times 2)$ e $(2 \times 3)$, respectivamente.

Substituído os fluxos monetários entre os setores da região $\mathrm{F}, z_{i j}^{F F}$ e $z_{i j}^{F M}$, obtidos em (22) e (24) em (21), chega-se a:

$$
X_{1}^{F}=a_{11}^{F F} \cdot X_{1}^{F}+a_{12}^{F F} \cdot X_{2}^{F}+a_{13}^{F F} \cdot X_{3}^{F}+a_{11}^{F M} \cdot X_{1}^{M}+a_{12}^{F M} \cdot X_{2}^{M}+Y_{1}^{F}
$$


isolando a demanda final, $Y_{1}^{F}$, na equação 26 , e colocando em evidência a produção do setor 1, da região $\mathrm{F}, X_{1}^{F}$, tem-se:

$$
\left(1-a_{11}^{F F}\right) X_{1}^{F}-a_{12}^{F F} \cdot X_{2}^{F}-a_{13}^{F F} \cdot X_{3}^{F}-a_{11}^{F M} \cdot X_{1}^{M}-a_{12}^{F M} \cdot X_{2}^{M}=Y_{1}^{F}
$$

Equações similares poderão ser obtidas para as demais demandas finais, $Y_{2}^{F}, Y_{3}^{F}, Y_{1}^{M}, Y_{2}^{M}$.

Utilizando as quatro matrizes que contêm informações sobre os coeficientes, dois vetores de produção total, um para cada região $X^{F}$ e $X^{M}$, e os dois vetores de demanda final regionais, $Y^{F}$ e $Y^{M}$, além das cinco equações de demanda final, construídas com base na equação (27), o modelo inter-regional pode ser representado na forma matricial como se segue:

$$
\begin{aligned}
& \left(\mathbf{I}-\mathbf{A}^{F F}\right) X^{F}-\mathbf{A}^{F M} X^{M}=Y^{F} \\
& -\mathbf{A}^{M F} X^{F}\left(I-\mathbf{A}^{M M}\right) X^{M}=Y^{M}
\end{aligned}
$$

Definindo as matrizes:

$$
\mathbf{A}=\left[\begin{array}{c:c}
\mathbf{A}^{F F} & \mathbf{A}^{F M} \\
\hdashline \mathbf{A}^{\bar{M}} & \mathbf{A}^{M \bar{M}}
\end{array}\right] \quad X=\left[\begin{array}{c}
X^{F} \\
\hdashline X^{\bar{M}}
\end{array}\right] \quad Y=\left[\begin{array}{c}
Y^{F} \\
\hdashline Y^{\bar{M}}
\end{array}\right]
$$

o sistema inter-regional completo pode ser representado e solucionado como se segue:

$$
(\mathbf{I}-\mathbf{A}) X=Y \Rightarrow X=(\mathbf{I}-\mathbf{A})^{-1} Y
$$

de forma menos compacta pode-se apresentar a solução para o modelo de insumoproduto inter-regional para duas regiões:

$$
\left[\begin{array}{c}
X_{-}^{F} \\
\hdashline X^{M}
\end{array}\right]=\left\{\left[\begin{array}{c:c}
\mathbf{I} & 0 \\
\hdashline 0 & \mathbf{I}
\end{array}\right]-\left[\begin{array}{c:c}
\mathbf{A}^{F F} & \mathbf{A}^{F M} \\
\hdashline \mathbf{A}^{M F} & \mathbf{A}^{M M}
\end{array}\right]\right\}^{-1}\left[\begin{array}{c}
Y^{F} \\
\hdashline Y^{M}
\end{array}\right]
$$

Nas seções anteriores foram descritas as principais metodologias para a construção de modelos nacionais e inter-regionais, bem como a composição do modelo utilizado no trabalho para testar a validade do teorema de Heckscher-Ohlin, para as 
cinco macrorregiões brasileiras e para o Brasil como um todo. A próxima seção traz a descrição da metodologia utilizada para testar a validade do teorema, bem como os ajustes realizados para a utilização dos dados disponíveis.

\subsection{Metodologia utilizada para testar o teorema de Heckscher-Ohlin}

Nesta seção, o objetivo é descrever a forma como o teorema de HeckscherOhlin foi testado para três níveis de comércio: Brasil e seus principais parceiros comerciais no exterior; comércio das cinco macrorregiões com o exterior e comércio doméstico entre as cinco macrorregiões. A metodologia está baseada no modelo desenvolvido por Leamer (1984) e utilizado por Machado (1997), ${ }^{28}$ para testar o teorema.

Para testar a validade do teorema de Heckscher-Ohlin, de acordo com Leamer (1984), faz-se necessário determinar os requisitos diretos e indiretos de cada um dos fatores de produção presentes nas exportações, nas importações, nas exportações líquidas (exportação-importação) e no consumo doméstico. Na equação 28 encontram-se expressas as informações necessárias e a forma como são utilizadas, para que seus resultados possibilitem a verificação da validade do teorema de Heckscher-Ohlin.

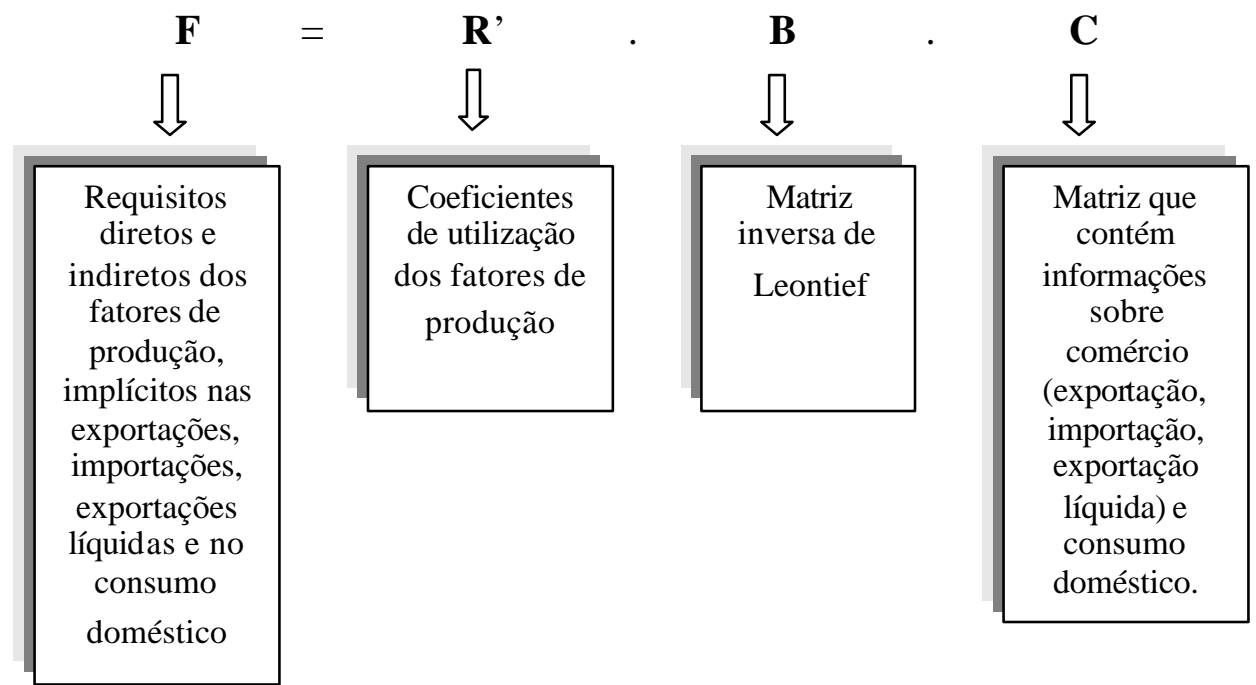

\footnotetext{
${ }^{28}$ Apresentados no capítulo 3 do presente trabalho.
} 
A matriz $\mathbf{R}$, que contém os coeficientes diretos de utilização dos fatores de produção, é determinada pela seguinte expressão:

$$
\mathbf{R}=\hat{\mathbf{Q}}^{-1} \cdot L
$$

onde $\hat{\mathbf{Q}}^{-1}$ é a inversa diagonal do vetor $Q$, que contém os dados do total produzido em cada um dos $\mathrm{n}$ setores da economia doméstica e $\mathbf{L}$ é uma matriz que contém informações referentes às quantidades dos fatores de produção empregados em cada um dos setores da economia local.

A obtenção da matriz inversa de Leontief, $\mathbf{B}$, encontra-se descrita no item 4.1.1 do presente capítulo e representa os requisitos diretos e indiretos, necessários à produção em cada um dos $\mathrm{n}$ setores. Com relação à matriz $\mathbf{C}$, ela contém as seguintes informações: exportação efetuada da economia local para os principais parceiros no comércio internacional ou para as demais regiões no comércio interno; importação que a economia doméstica faz no comércio internacional ou das demais regiões na economia local; exportação liquida (exportação - importação) e o consumo final doméstico.

A Figura 18 mostra as informações necessárias para que o teorema de Heckscher-Ohlin possa ser testado para cada uma das formas de comércio consideradas no trabalho. No comércio existente entre o Brasil e o exterior, foi considerada a matriz inversa de Leontief, B, do Brasil, assim como a matriz $\mathbf{R}$. Na matriz $\mathbf{C}$, foram consideradas as exportações e importações que o Brasil efetuou com os principais parceiros comerciais no exterior. O consumo doméstico foi definido como o consumo realizado dentro do país pelas famílias, pelo governo e pelos investimentos.

Para verificar a validade do teorema no comércio externo das macrorregiões, de acordo com a Figura 18, fez-se necessário elaborar uma matriz $\mathbf{B}$ e uma matriz R, para cada uma das regiões. A matriz $\mathbf{C}$ contém informações sobre as exportações e importações de cada uma das regiões, realizadas com cada um dos principais parceiros comerciais no mercado mundial. $\mathrm{O}$ consumo doméstico considerado foi aquele observado em cada uma das regiões. 
Pode-se verificar, na Figura 18, que, no âmbito do comércio doméstico de cada uma das cinco macrorregiões o que muda em relação ao comércio externo é apenas a matriz C. Ela passa a conter informações acerca das exportações e importações que cada uma das regiões realiza, em relação às demais.

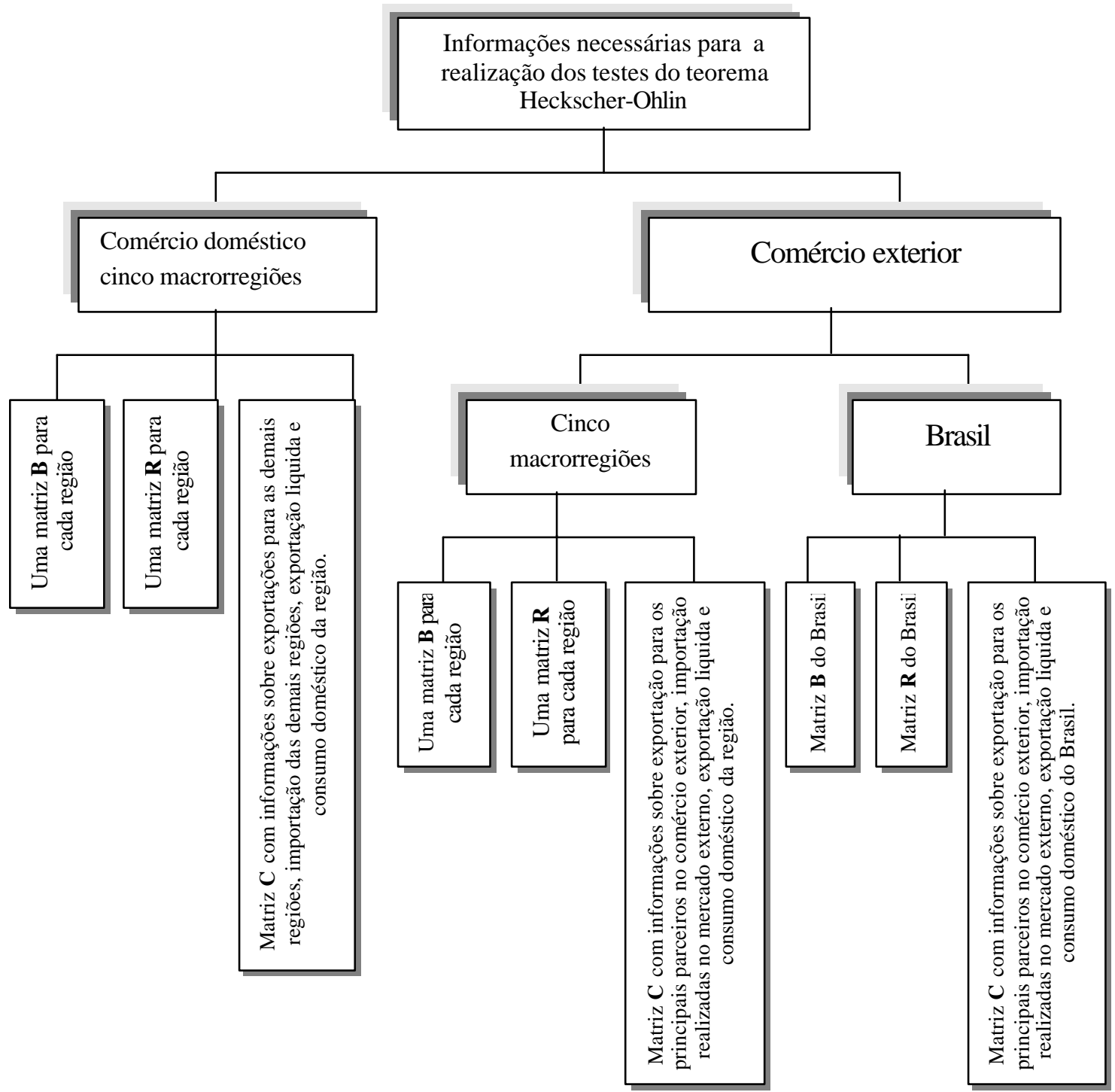

Figura 18 - Informações que deverão ser observadas para a realização dos testes de validade do teorema de Heckscher-Ohlin, para cada uma das formas de comércio consideradas. 
Depois de obtidas as informações para as matrizes $\mathbf{R}, \mathbf{B}$ e $\mathbf{C}$, pôde-se determinar a matriz $\mathbf{F}$, como apresentada na equação 28. Ela demonstra os requisitos diretos e indiretos de cada um dos fatores, presentes nas exportações e nas importações, exportações líquidas e no consumo doméstico.

Com os resultados de $\mathbf{F}$, pôde-se verificar a dotação relativa dos fatores e confirmar, ou não, a validade do teorema de Heckscher-Ohlin. Para que o eorema seja confirmado as exportações devem utilizar relativamente um volume maior do fator de produção definido como abundante, em relação às importações, conforme critérios apresentados na seção 3.1.2.3 deste trabalho.

Nas seções já descritas nesse capítulo, foram apresentados os modelos insumoproduto nacional e inter-regional utilizados no trabalho, além da metodologia empregada para testar a validade do teorema de Heckscher-Ohlin. As próximas seções têm como objetivo descrever a forma como os dados foram tratados, bem como, a fonte dos mesmos.

\subsection{Tratamento dos dados}

O que se busca, nesta seção, é apresentar as fontes dos dados utilizados para testar a validade do teorema de Heckscher-Ohlin no comércio externo do Brasil e no comércio interno e externo das cinco macrorregiões. A base para o levantamento das informações encontra-se descrita na Figura 18 e na equação 28 e são as matrizes inversas de Leontief, $\mathbf{B}_{\mathrm{i}}{ }^{29}$, as matrizes de coeficientes de utilização dos fatores de produção, $\mathbf{R}_{\mathbf{i}}$, e as matrizes $\mathbf{C}_{\mathrm{i}}$, que trazem informações sobre comércio e consumo doméstico.

\footnotetext{
${ }^{29}$ O coeficiente “i” refere-se às informações para o Brasil e para as regiões, tanto no comércio doméstico quanto no externo.
} 


\subsubsection{Fonte dos dados utilizados na construção das matrizes inversas de Leontief regionais e nacionais}

Para atender aos objetivos propostos no trabalho fez-se necessária a utilização de uma matriz inversa de Leontief, para cada uma das cinco macrorregiões brasileiras: Sul, Norte, Nordeste, Sudeste e Centro-Oeste, e também uma para o Brasil como um todo, no ano de 1999. Para tanto, foram utilizadas as informações do modelo interregional e da matriz insumo-produto do Brasil, construídas por Guilhoto et al., op. cit. (2003), referentes ao ano de 1999.

A estimativa das matrizes regionais e do Brasil foi realizada de acordo com a metodologia descrita na seção 4.1 do presente capítulo, e também com base em informações censitárias, levantadas para a construção das matrizes obtidas por Guilhoto et al., op. cit. (2003). Como resultado, foram construídas as matrizes de uso, U, e produção, $\mathbf{V}$ nacional e para o modelo inter-regional. Elas foram, então, ttilizadas para a construção das matrizes $\mathbf{B}$ regionais e nacional, o mais próximas possível da matriz inversa de Leontief.

A matriz $\mathbf{V}$ traz a informação de quanto cada setor produz de cada um dos bens e serviços. Ao longo da linha, tem-se o que cada setor produziu de cada bem e serviço. Ao longo da coluna, tem-se a informação de quais setores produziram um determinado produto. A estrutura resumida da matriz V é apresentada na Figura 19. 


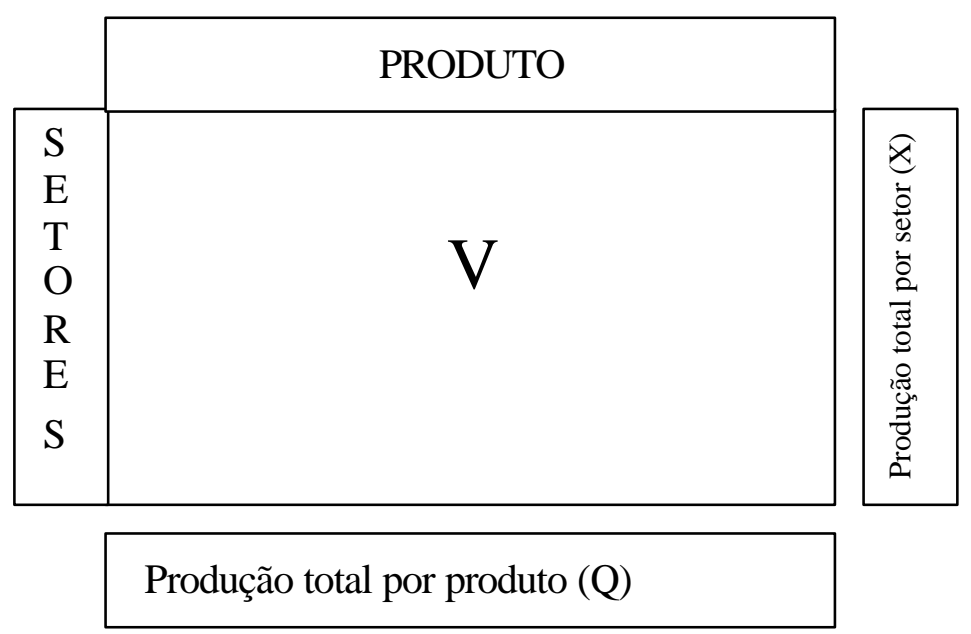

Figura 19 - Esquema resumido da forma da matriz de produção, V.

A matriz $\mathbf{U}$ mostra os produtos que cada setor está utilizando em seu processo de produção. Na linha, tem-se a informação do destino do produto por setor. A coluna mostra o que cada setor consumiu de cada um dos produtos. A estrutura básica da matriz de uso é apresentada na Figura 20.

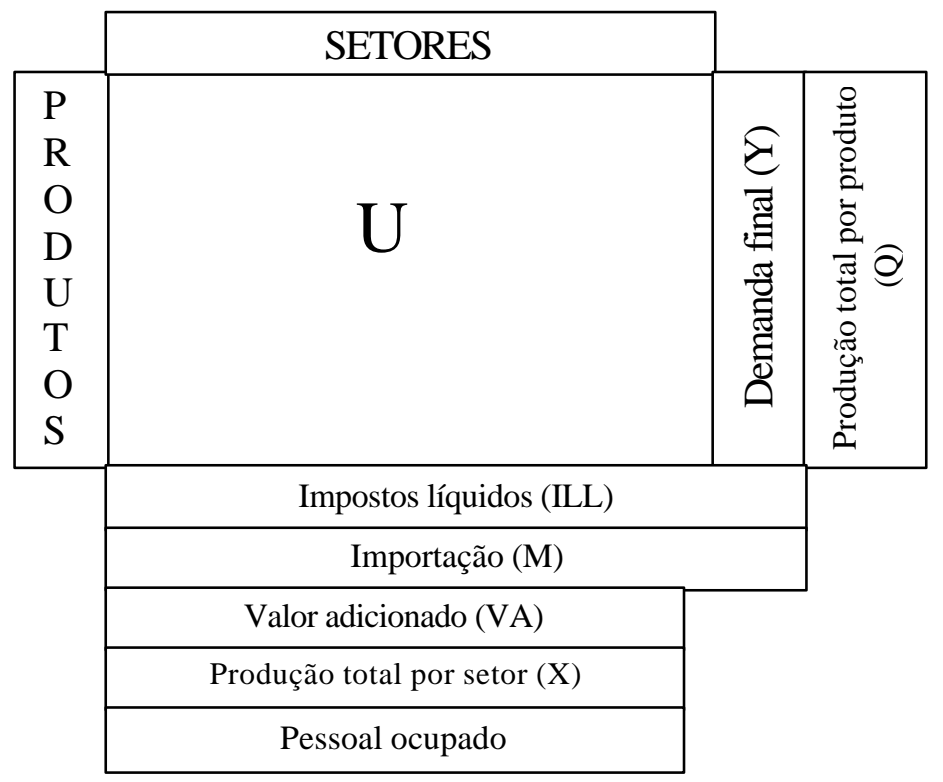

Figura 20 - Esquema resumido da forma da matriz de uso, $\mathbf{U}$. 
Com base nas informações existentes nas matrizes: $\mathbf{U}$ e $\mathbf{V}$, pôde-se chegar à matriz $\mathbf{Z}$, que representa as magnitudes dos fluxos interssetorias. A Matriz $\mathbf{Z}$ tem estrutura semelhante à da matriz $\mathbf{U}$, mas com informações setor x setor. Para se chegar à matriz $\mathbf{Z}$ o primeiro passo foi construir a matriz $\mathbf{D}$, que define quanto cada setor produz de cada bem e serviço. Para construir a matriz $\mathbf{D}$ cada elemento da matriz $\mathbf{V}$ foi dividido pela produção total do produto:

$$
d_{i j}=\frac{v_{i j}}{q_{j}} \text { ou na forma matricial } \quad \mathbf{D}=\mathbf{V} \cdot\left(\hat{\mathbf{Q}}_{j}\right)^{-1}
$$

Após obtida a matriz $\mathbf{D}$, a matriz $\mathbf{Z}$ pôde ser definida pela multiplicação das matrizes D e U:

$$
\mathbf{Z}=\mathbf{D} . \mathbf{U}
$$

O método utilizado para determinar a matriz $\mathbf{Z}$ é definido como tecnologia baseada na indústria (TBI) (setor $\mathrm{x}$ setor). Outras formas podem ser consideradas, como a tecnologia baseada no produto (TBP), mas não foram utilizadas neste trabalho ${ }^{30}$. Optou-se pela metodologia TBI (setor x setor), por poder se chegar à matriz mais próxima possível da matriz de Leontief, obtida a partir das informações disponíveis nas matrizes de uso e de produção. Depois de definida a matriz $\mathbf{Z}$, pôde-se chegar à matriz A, dividindo cada elemento de $\mathbf{Z}$ pela produção total correspondente ao setor em questão:

$$
a_{i j}=\frac{z_{i j}}{x_{j}}, \text { ou na forma matricial } \quad \mathbf{A}=\mathbf{Z} \cdot\left(\hat{\mathbf{X}}_{j}\right)^{-1}
$$

A matriz de coeficientes técnicos diretos e indiretos, conhecida como matriz inversa de Leontief, é definida como $\mathbf{B}=(\mathbf{I}-\mathbf{A})^{-1}$. Para se testar a validade do teorema de Heckscher-Ohlin, uma matriz $\mathbf{B}$ nacional foi construída, assim como uma para cada região.

\footnotetext{
${ }^{30}$ Para maiores detalhes, ver Miller e Blair (1985).
} 
As informações das matrizes de uso e de produção foram geradas originalmente para 90 setores e 141 produtos. Para o presente trabalho, os 90 setores foram agregados em 31, de acordo com os dados do Anexo A.

O objetivo desta seção foi apresentar a metodologia e a fonte dos dados utilizados na construção das matrizes inversas de Leontief, nacional e regionais. A próxima seção trata da construção das matrizes de coeficientes diretos dos fatores de produção.

\subsubsection{Construção da matriz R: nacional e regionais}

Para que o teorema de Heckscher-Ohlin pudesse ser testado, dois fatores de produção deveriam ser definidos. $\mathrm{Na}$ abordagem inicial do teorema, os fatores de produção utilizados foram: capital e trabalho. Após o trabalho de Leontief (1953), quando foi verificado o paradoxo de Leontief, novos trabalhos foram desenvolvidos, utilizando como fatores de produção, para testar a validade do teorema, a qualificação da mão-de-obra, abordagem que será utilizada neste trabalho.

Nesta seção, o objetivo é descrever o critério empregado para a determinação da qualificação da mão-de-obra, bem como as fontes de dados utilizadas e suas limitações.

A matriz $\mathbf{L}$ apresentada na seção 4.2, que contém informações sobre a utilização dos fatores de produção, no caso a mão-de-obra qualificada e a não qualificada, foi construída levando em consideração os anos de estudos das pessoas ocupadas, por setor. $\mathrm{O}$ critério para a classificação da mão-de-obra foi o seguinte:

- foi classificada como qualificada a mão-de-obra que possui 11 anos ou mais de escolaridade;

- $\quad$ como mão-de-obra não-qualificada, foram consideradas as pessoas ocupadas com 10 anos ou menos de estudo. 
Os dados necessários para a classificação da mão-de-obra, por qualificação, podem ser obtidos através de duas fontes: dos microdados da PNAD (IBGE, 1999b) e da Relação Anual de Informações Sociais -RAIS- (Brasil, 1999). A periodicidade de ambas as fontes é anual. Na Figura 21, está apresentada a forma como as informações se encontram descritas na PNAD e na RAIS.

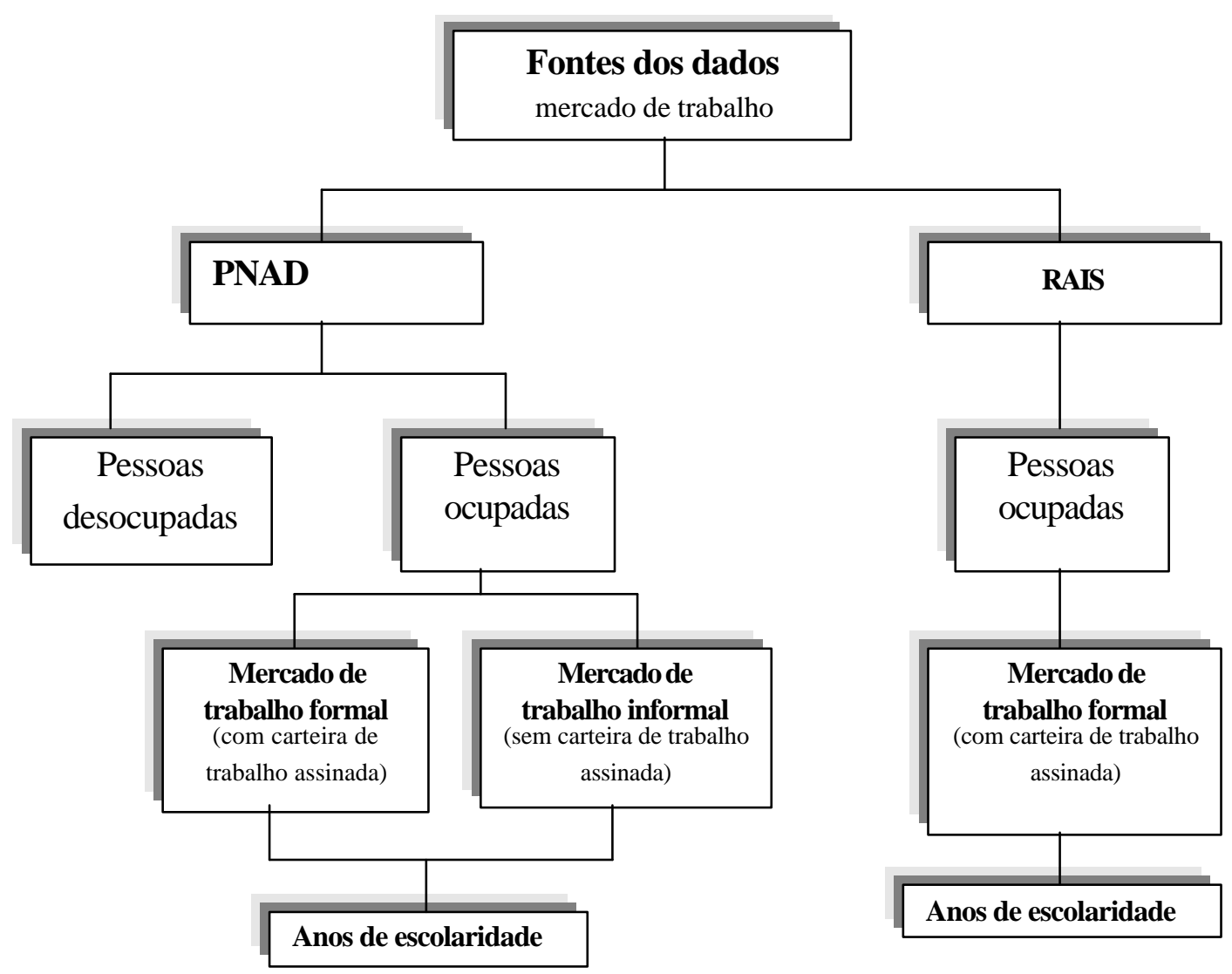

Figura 21 - Estrutura das informações sobre o mercado de trabalho, que poderão ser utilizadas para quantificar e qualificar a mão-de-obra ocupada, por setor de atividade, no Brasil e nas regiões.

Os dados da RAIS não foram utilizados no presente trabalho. A opção de priorizar a utilização dos dados da PNAD encontra-se associada ao fato de que o levantamento realizado por esta pesquisa leva em consideração os dois segmentos do mercado de trabalho, formal e informal, como pode ser observado na Figura 21. Já os 
levantamentos realizados pela RAIS levam em consideração apenas o mercado de trabalho formal, ou seja, as informações obtidas pela RAIS são restritas aos trabalhadores com a carteira de trabalho assinada.

Uma outra desvantagem na utilização dos dados da RAIS está em sua deficiência com relação ao levantamento dos anos de estudo dos trabalhadores. As informações publicadas na RAIS são fornecidas pelas empresas que empregam o trabalhador. Como muitas informações cadastrais dos trabalhadores não são atualizadas nas empresas, as informações repassadas ao Ministério, através da RAIS, são desatualizadas. Assim, a qualificação da mão-de-obra poderia ser sub-estimada ${ }^{31}$. Esse problema foi amenizado com a pesquisa realizada pela PNAD, pois o questionário é respondido, através de amostragem, pelos próprios indivíduos, e não pelas empresas.

Os dados da PNAD, que permitem obter informação sobre o número de pessoas ocupadas, por setor, em cada uma das regiões no Brasil, são os microdados. O critério adotado para a compatibilização entre as atividades da PNAD e da matriz insumoproduto encontra-se descrito no Anexo B. A compatibilização dos dados, feita no trabalho, foi a mesma adotada no sistema de Contas Nacionais (considerando-se apenas como fonte de dados a PNAD), no ano de 1999. As únicas modificações feitas dizem respeito à inclusão de duas novas atividades 463 (loteria) e 801 (consulados e embaixadas) na atividade 38 (serviços prestados às famílias) da matriz insumo-produto. Alguns setores, que estão desagregados na matriz insumo-produto, encontram-se agregados na PNAD, de acordo com o Anexo B. Não há possibilidade de desagregação dos dados da PNAD para tais atividades. Esta é a justificativa para que, no presente trabalho, apenas 31 setores fossem considerados.

A variável selecionada a partir da qual os dados foram gerados foi a V9907, que diz respeito ao código da atividade principal do empreendimento ${ }^{32}$, do trabalho único ou

\footnotetext{
${ }^{31}$ Algumas empresas têm registrado, no cadastro do trabalhador, os anos de estudos que este tinha quando foi contratado pela mesma. Para os trabalhadores empregados há mais tempo nessas empresas, as chances de que a qualificação dessa mão-de-obra seja subestimada são maiores.

${ }^{32}$ A relação de códigos de atividades encontra-se no Anexo IV das notas metodológicas da PNAD de 1999.
} 
principa $^{33}$, que o morador de 10 anos ou mais tinha na semana de referência de 21 a 27 de setembro de 1999. O cuzamento dessa variável com a V4738, que estratifica os grupos de anos de estudos, resultou no grau de escolaridade das pessoas ocupadas, em cada um dos setores, no ano de 1999, para cada uma das unidades da Federação, de acordo com a seguinte classificação:

1- $\quad$ sem instrução e menos de 1 ano de estudo;

2- de 1 a 3 anos de estudo;

3- de 4 a 7 anos de estudo;

4- de 8 a 10 anos de estudo;

5- de 11 a 14 anos de estudo;

6- 15 anos de estudo ou mais;

7- não determinado, sem declaração e não aplicável.

A principal justificativa para a adoção da classificação dessas faixas de escolaridade foi a dificuldade de classificar os anos de estudo, principalmente para quem não mais freqüenta a escola. Houve modificações, ao longo dos anos, com relação ao tempo de duração das etapas. Por exemplo, o elementar primário correspondia a 6 anos de estudo, ao passo que hoje o ensino fundamental tem a duração de 8 anos. Outro

\footnotetext{
${ }^{33}$ De acordo com as notas metodológicas da PNAD, 1999 foi considerado como "trabalho principal da semana de referência o único trabalho que a pessoa teve nesse período. Para a pessoa que teve mais de um trabalho, ou seja, para a pessoa ocupada em mais de um empreendimento na semana de referência, adotaram-se os seguintes critérios, obedecendo à ordem enumerada, para definir o principal desse período:

$1^{-}$) O trabalho da semana de referência, no qual teve maior tempo de permanência no período de referência de 365 dias, foi considerado como principal;

$\left.2^{\underline{a}}\right)$ Em caso de igualdade no tempo de permanência no período de referência de 365 dias, considerou-se como principal o trabalho remunerado da semana de referência ao qual a pessoa normalmente dedicava maior número de horas semanais. Esse mesmo critério foi adotado para definir o trabalho principal da pessoa que, na semana de referência, teve somente trabalhos não remunerados e que apresentaram o mesmo tempo de permanência no período de referência de 365 dias e

3) Em caso de igualdade, também, no número de horas trabalhadas, considerou-se como principal o trabalho da semana de referência que normalmente proporcionava maior rendimento."
} 
problema, no presente, diz respeito ao tempo de duração das faculdades que pode ser, em sua grande maioria, de 4 a 5 anos, há casos de 3 e de 6 anos, também. No ensino médio hoje o curso regular tem a duração de 3 ou 4 anos (este último é o profissionalizante, como magistério, por exemplo) e o curso supletivo, no máximo de 3 anos.

O que se buscou, na classificação da variável V4738, foi sempre captar um ciclo que tenha sido concluído, não até seu final, mas que tenha sido iniciado por ele. Tem-se que, de 1 a 3 anos de estudo, as pessoas não têm nenhum ciclo concluído. De 4 a 7 anos, elas têm pelo menos um ciclo concluído, ou seja, o ensino básico ou primário, como era conhecido antes, mas não têm o ensino fundamental completo. Na faixa de 8 a 10 anos, as pessoas têm o ensino fundamental completo, mas o ensino médio, não.

Depois de geradas as informações, os dados foram agrupados de acordo com os 31 setores do Anexo B, para cada uma das regiões, e então reagrupadas em: qualificada e não qualificada, baseadas no critério já apresentado nesta seção. Com base nessas informações, observoutse, então, o percentual de mão-de-obra qualificada e não qualificada em cada um dos 31 setores nas regiões e no Brasil daí, aplicou-se esse percentual às informações apresentadas nas matrizes nacional e regionais. A partir dessas informações, foram construídas as matrizes $\mathbf{R}$, de acordo com a equação (29).

\subsubsection{Fonte e tratamento dos dados utilizados na construção das matrizes $C$}

As informações relativas ao comércio doméstico, realizado entre as regiões, foram obtidas a partir das informações das matrizes inter-regionais, construídas por Guilhoto et al., op. cit. (2003). Foram consideradas as exportações e as importações referentes ao consumo intermediário e a demanda final (formação de capital, exportação, variação de estoque consumo da administração pública e das famílias), para cada uma das regiões.

O volume das exportações, destinadas ao consumo intermediário, da região Norte, por exemplo, para as demais regiões foi obtido através da soma nas linhas (para 
cada um dos 31 setores) das matrizes 2ci, 3ci, 4ci e 5ci (ver Quadro 1). As exportações destinadas à demanda final, para cada um dos 31 setores, foram obtidas pela soma nas linhas das matrizes $\mathbf{2 y}, \mathbf{3 y}, \mathbf{4 y}$ e $\mathbf{5 y}$. As exportações totais da região Norte referem-se à soma, para cada um dos 31 setores, das exportações destinadas ao consumo intermediário e àdemanda final.

\begin{tabular}{|l|c|c|c|c|c|c|c|c|c|c|}
\hline \multicolumn{9}{|c|}{ CONSUMO INTERMEDIÁRIO } & \multicolumn{5}{|c|}{ DEMANDA FINAL } \\
\hline & N & NE & CO & SE & S & N & NE & CO & SE & S \\
\hline N & $1 \mathrm{ci}$ & $2 \mathrm{ci}$ & $3 \mathrm{ci}$ & $4 \mathrm{ci}$ & $5 \mathrm{ci}$ & $1 \mathrm{y}$ & $2 \mathrm{y}$ & $3 \mathrm{y}$ & $4 \mathrm{y}$ & $5 \mathrm{y}$ \\
\hline NE & $6 \mathrm{ci}$ & $7 \mathrm{ci}$ & $8 \mathrm{ci}$ & $9 \mathrm{ci}$ & $10 \mathrm{ci}$ & $6 \mathrm{y}$ & $7 \mathrm{y}$ & $8 \mathrm{y}$ & $9 \mathrm{y}$ & $10 \mathrm{y}$ \\
\hline CO & $11 \mathrm{ci}$ & $12 \mathrm{ci}$ & $13 \mathrm{ci}$ & $14 \mathrm{ci}$ & $15 \mathrm{ci}$ & $11 \mathrm{y}$ & $12 \mathrm{y}$ & $13 \mathrm{y}$ & $14 \mathrm{y}$ & $15 \mathrm{y}$ \\
\hline SE & $16 \mathrm{ci}$ & $17 \mathrm{ci}$ & $18 \mathrm{ci}$ & $19 \mathrm{ci}$ & $20 \mathrm{ci}$ & $16 \mathrm{y}$ & $17 \mathrm{y}$ & $18 \mathrm{y}$ & $19 \mathrm{y}$ & $20 \mathrm{y}$ \\
\hline S & $21 \mathrm{ci}$ & $22 \mathrm{ci}$ & $23 \mathrm{ci}$ & $24 \mathrm{ci}$ & $25 \mathrm{ci}$ & $21 \mathrm{y}$ & $22 \mathrm{y}$ & $23 \mathrm{y}$ & $24 \mathrm{y}$ & $25 \mathrm{y}$ \\
\hline
\end{tabular}

Quadro 1 - Formato resumido do consumo intermediário e da demanda final das matrizes inter-regionais.

De acordo com o Quadro 1, a importação que a região Norte faz das outras quatro regiões destinada ao consumo intermediário, é obtida pela soma nas linhas, para cada um dos 31 setores, das matrizes 6ci, 11ci, 16ci e 21ci. O valor das importações que o Norte faz das outras regiões para a demanda final corresponde à soma nas linhas das matrizes 6y, 11y, 16y e 21y. O valor total das importações do Norte foi determinado pela soma, para cada um dos 31 setores, das importações destinadas ao consumo intermediário e àdemanda final.

As informações necessárias à construção da matriz $\mathbf{C}$ em relação ao consumo final doméstico das regiões correspondem as matrizes 1y (Norte), 7y (Nordeste), 13y (Centro-Oeste), 19y (Sudeste) e 25y (Sul) do Quadro 1. Para as macrorregiões e para o Brasil foram consideradas as seguintes variáveis de demanda final como consumo doméstico: formação de capital, consumo das famílias e consumo do governo

Os dados levantados sobre o comércio com o exterior foram obtidos em BRASIL (2003). Foram coletas as informações sobre a importação e a exportação de cada uma das unidades da Federação. Consideraram-se os blocos econômicos mais 
importantes com quem o Brasil comercializou em 1999: União Européia, Mercosul e Ásia. Os Estados Unidos foram considerados separadamente do bloco Nafta, por serem destino de $87 \%$ das exportações realizadas pelo Brasil ao bloco, e por ser origem de $88 \%$ das importações dele advindas. Juntos, os blocos selecionados e os Estados Unidos respondem por $77 \%$ das exportações efetuadas pelo Brasil no mercado internacional e por $81 \%$ das importações (Brasil, 2003). O comércio do Brasil com os demais países foi agrupado como resto do mundo.

As informações foram coletadas para 6.775 produtos exportados e 8.366 produtos importados, agrupadas para os 141 produtos do modelo regional, construído por Guilhoto et al., op. cit. (2003), considerando as cinco macrorregiões e o Brasil. Para transformar as informações agrupadas para os 141 produtos, em valores de importação e exportação, considerando os 31 setores, utilizou-se a agregação apresentada no Anexo C. Esses valores, que se encontravam em dólares, foram transformados em reais de 1999, com base na taxa média de câmbio obtida para o referido período $(1,8147)$.

Optou-se por não desagregar os valores das importações e das exportações com base nos dados obtidos para as matrizes regionais e nacional, em decorrência de algumas pressuposições que deveriam ser adotadas em tal procedimento. Elas poderiam gerar resultados um pouco distantes da realidade do comércio verificado com o exterior ${ }^{34}$. $\mathrm{Na}$ escolha da metodologia de agregação dos dados sobre exportação e importação, o que se buscou foi ser fiel com a realidade do comércio verificado em cada um dos setores, pois essas variáveis sobre o comércio externo foram objetos de estudo de grande importância no presente trabalho.

Neste capítulo, o objetivo foi descrever a metodologia empregada no trabalho para que o teorema pudesse ser testado. Também foram apresentadas as fontes dos dados e os tratamentos necessários para que os mesmos pudessem ser utilizados. O próximo

\footnotetext{
${ }^{34}$ Como, por exemplo, a pressuposição de que as importações e as exportações deveriam ser classificadas nos setores, considerando a participação dos mesmos no valor da produção. Com isso alguns setores que não eram exportadores e importadores, mas que eram produtores de bens e serviços comercializados com o exterior, poderiam apresentar valores para exportação ou importação destes bens e serviços.
} 
capítulo tem como objetivo apresentar os resultados da aplicação da metodologia descrita no presente capítulo. 


\section{ANÁLISE DOS RESULTADOS}

O objetivo deste capítulo é apresentar os resultados obtidos com o propósito de testar a validade do teorema de Heckscher-Ohlin e os resultados verificados no dimensionamento do comércio intra-indústria. Esses resultados referem-se aos três níveis de comércio considerados no trabalho: comércio externo realizado entre o Brasil e a Ásia, a União Européia, o Mercosul, os Estados Unidos e o resto do mundo; comércio externo observado entre cada uma das macrorregiões (Norte, Nordeste, Centro-Oeste, Sudeste e Sul) e o exterior, considerando os mesmos parceiros comerciais observados para o Brasil e comércio doméstico verificado entre as cinco macrorregiões.

\subsection{Testes do teorema de Heckscher-Ohlin}

Para que o teorema pudesse ser testado, fez-se necessário, em primeiro lugar, verificar a abundância relativa dos fatores de produção: mão-de-obra qualificada e não qualificada. Para tanto, os resultados das exportações líquidas e do consumo doméstico foram utilizados, de acordo com os critérios observados na seção 3.1.2.3 do presente trabalho.

Depois de identificada a abundância relativa dos fatores no Brasil ou região, o segundo passo para que o teorema pudesse ser constatado foi verificar se a utilização desses fatores nas exportações e nas importações se encontrava de acordo com a dotação definida. Para tanto, foi observada a utilização relativa da mão-de-obra qualificada e não qualificada ra produção dos bens importados e exportados. Espera-se que as exportações seja relativamente mais intensivas, na utilização do fator definido como abundante, e as importações mais intensivas, no fator verificado como escasso. 


\subsubsection{Teste da validade do teorema de Heckscher-Ohlin para o comércio externo do Brasil}

Os resultados dos testes de validade do teorema de Heckscher-Ohlin para o comércio observado entre o Brasil e a Ásia, os Estados Unidos, o Mercosul, a União Européia e o resto do mundo. Os dados que constam no Quadro 2 são os resultados verificados para a matriz $\mathbf{F}$, definida na equação (28) da seção 4.2 deste trabalho. Eles representam o volume de mão-de-obra qualificada e não qualificada utilizada na produção dos bens e serviços exportados, importados, consumidos internamente e nas exportações líquidas. $\mathrm{O}$ resultado denominado como relativo corresponde à razão entre os fatores de produção, mão-de-obra qualificada (q) e mão-de-obra não qualificada (nq).

Considerando o comércio realizado entre o Brasil e a Ásia, os Estados Unidos e a União Européia, pôde-se constatar, de acordo com os dados do Quadro 2, que o Brasil apresentou abundância relativa no fator de produção mão-de-obra não qualificada, pois o mesmo foi exportador líquido desse fator para esses parceiros, $\mathrm{nq}_{\mathrm{t}}{ }^{35}>0$, e importador líquido de mão-de-obra qualificada, $\mathrm{q}_{\mathrm{t}}<0$. De acordo com Leamer (1984), quando os sinais dos fatores nas exportações líquidas forem opostos, o fator que apresentar o sinal positivo deverá ser definido como o relativamente abundante no país. Para que o teorema de Heckscher-Ohlin fosse constatado, a utilização do fator de produção definido como abundante deveria estar presente em um volume relativamente maior nas exportações, em relação às importações. Os resultados do Quadro 2 confirmam a validade do teorema para o comércio realizado entre o Brasil e a Ásia, os Estados Unidos e a União Européia, pois as exportações para esses parceiros utilizavam

\footnotetext{
${ }^{35}$ Algumas notações serão utilizadas ao longo do texto, para indicar a utilização dos fatores nas exportações, importações, exportações líquidas e consumo doméstico. Estas se encontram abaixo definidas:

nqt e qt: referem-se ao volume de mão-de-obra não qualificada e qualificada, respectivamente, utilizadas na produção de bens e serviços presentes nas exportações líquidas;

nqc e qc: referem-se ao volume de mão-de-obra não qualificada e qualificada, respectivamente, utilizadas na produção de bens e serviços presentes no consumo doméstico;

nqe e qe: referem-se ao volume de mão-de-obra não qualificada e qualificada, respectivamente, utilizadas na produção de bens e serviços presentes nas exportações;

nqi e qi: referem-se ao volume de mão-de-obra não qualificada e qualificada, respectivamente, utilizadas na produção de bens e serviços presentes nas importações.
} 
relativamente uma proporção maior de mão-de-obra não qualificada, em relação às importações, $\mathrm{q}_{\mathrm{e}} / \mathrm{nq}_{\mathrm{e}}<\mathrm{q}_{\mathrm{i}} / \mathrm{nq}_{\mathrm{i}}$.

Pôde-se verificar que no comércio com o Mercosul houve exportação liquida de mão-de-obra qualificada, qt > 0, e importação liquida de mão-de-obra não qualificada nqt $<0$. De acordo com esse resultado a abundância relativa de mão-de-obra qualificada, no Brasil ficou definida no comércio com esse bloco. Como as exportações foram relativamente mais intensivas em mão-de-obra qualificada em relação às importações, qe/nqe > qi/nqi, o teorema de Heckscher-Ohlin pôde ser verificado no comércio observado entre o Brasil e o Mercosul (ver Quadro 2).

\begin{tabular}{|c|c|c|c|c|}
\hline $\begin{array}{l}\text { Fatores de } \\
\text { produção }\end{array}$ & $\begin{array}{r}\text { Exportação } \\
\text { (e) }\end{array}$ & $\begin{array}{r}\text { Importação } \\
\text { (i) }\end{array}$ & $\begin{array}{l}\text { Exportação } \\
\text { Liquida }^{1}(\mathrm{t})\end{array}$ & $\begin{array}{c}\text { Consumo } \\
\text { doméstico (c) }\end{array}$ \\
\hline & & & & Ásia \\
\hline Não qualificada (nq) & 508.625 & 292.162 & 216.464 & 40.794 .718 \\
\hline Qualificada (q) & 104.264 & 118.255 & -13.991 & 13.557.110 \\
\hline Relativo (q/nq) & 0,2050 & 0,4048 & $-0,0646$ & 0,3323 \\
\hline \multicolumn{5}{|c|}{ Estados Unidos } \\
\hline Não qualificada (nq) & 717.003 & 493.727 & 223.276 & 40.794 .718 \\
\hline Qualificada (q) & 194.383 & 206.222 & -11.838 & 13.557 .110 \\
\hline Relativo (q/nq) & 0,2711 & 0,4177 & $-0,0530$ & 0,3323 \\
\hline \multicolumn{5}{|c|}{ Mercosul } \\
\hline Não qualificada (nq) & 377.362 & 653.850 & -276.488 & 40.794 .718 \\
\hline Qualificada (q) & 119.376 & 108.390 & 10.985 & 13.557 .110 \\
\hline Relativo (q/nq) & 0,3163 & 0,1658 & $-0,0397$ & 0,3323 \\
\hline \multicolumn{5}{|c|}{ União Européia } \\
\hline Não qualificada (nq) & 1.388 .498 & 635.052 & 753.445 & 40.794 .718 \\
\hline Qualificada (q) & 239.413 & 256.702 & -17.289 & 13.557.110 \\
\hline Relativo (q/nq) & 0,1724 & 0,4042 & $-0,0229$ & 0,3323 \\
\hline \multicolumn{5}{|c|}{ Resto do mundo } \\
\hline Não qualificada (nq) & 835.221 & 359.456 & 475.765 & 40.794 .718 \\
\hline Qualificada (q) & 183.583 & 132.215 & 51.368 & 13.557.110 \\
\hline Relativo (q/nq) & 0,2198 & 0,3678 & 0,1080 & 0,3323 \\
\hline
\end{tabular}

Quadro 2 - Utilização dos fatores de produção no comércio do Brasil com seus principais parceiros no mercado internacional, no ano de 1999.

Fonte: Resultados da pesquisa

${ }^{1}$ Exportação-importação 
Os resultados do Quadro 2 demonstram que, no comércio existente entre o Brasil e o resto do mundo, o país foi exportador líquido de ambos os fatores, mas definido como relativamente abundante em mão-de-obra não qualificada, pois qt/nqt < qc/nqc, ou seja, a relação mão-de-obra qualificada e não qualificada na exportação liquida, foi inferior a relação presente no consumo doméstico. Dessa forma o país pôde ser considerado como exportador líquido de mão-de-obra não qualificada. $\mathrm{O}$ teorema de Heckscher-Ohlin foi constatado, pois as exportações do Brasil para o resto do mundo foram relativamente mais intensivas em seu fator de produção definido como abundante, ou seja, mão-de-obra não qualificada e as importações relativamente mais intensivas em seu fator definido como escasso, mão-de-obra qualificada, qe/nqe < qi/nqi.

Considerando os resultados observados para o comércio do Brasil com o exterior, pôde-se verificar que o teorema de Heckscher-Ohlin foi considerado válido para o comércio do Brasil com todos os parceiros considerados no mercado mundial. Observou-se, também, que no comércio do Brasil com o Mercosul o país apresentou abundância relativa no fator de produção mão-de-obra qualificada. Esse resultado difere dos obtidos para o comércio com os demais parceiros no mercado internacional, onde o fator de produção definido como relativamente abundante foi a mão-de-obra não qualificada. Resultado semelhante foi observado por Vasconcelos (2001), mas o autor utilizou metodologia deferente para obter os resultados para o Mercosul e para o resto do mundo, como se pôde verificar na seção 3.2 do presente trabalho. Vale lembrar que Machado (1997) e Maia (2001), assim como outros autores, também verificaram a abundância relativa de mão-de-obra não qualificada no comércio verificado entre o Brasil e o resto do mundo, além de constatar a validade do teorema de Heckscher-Ohlin. Os resultados dos testes para as relações comerciais com o exterior e as macrorregiões podem ser verificados na seção seguinte. 


\subsubsection{Teste da validade do teorema de Heckscher-Ohlin para o comércio externo das regiões}

O objetivo desta seção é testar a validade o teorema de Heckscher-Ohlin no comércio observado entre cada uma das macrorregiões brasileiras e seus principais parceiros comerciais no mercado mundial. Nos Quadros 3 a 7, encontram-se os resultados observados a partir da aplicação da metodologia descrita no capítulo 4 do presente trabalho.

No Quadro 3, podem-se verificar os resultados observados para o comércio da região Centro-Oeste com a Ásia, os Estados Unidos, o Mercosul, a União Européia e o resto do mundo. No comércio dessa região com a Ásia, a União Européia e o resto do mundo, observou-se que o Centro-Oeste se apresentou como exportador líquido de mãode-obra não qualificada, nqt > 0, e como importador líquido de mão-de-obra qualificada, qt $<0$. Dessa forma, a região pôde ser considerada como relativamente abundante em mão-de-obra não qualificada, no comércio verificado com esses parceiros no mercado internacional. O teorema de Heckscher-Ohlin pôde ser confirmado para o comércio observado entre o Centro-Oeste e a Ásia, a União Européia e o resto do mundo, pois suas exportações foram relativamente mais abundantes em mão-de-obra não qualificada, qe/nqe < qi/nqi, fator esse definido como abundante nas relações comerciais observadas.

$\mathrm{Na}$ relação comercial observada entre o Centro-Oeste e os Estados Unidos, os resultados observados no Quadro 3 demonstram que a região foi importadora liquida de ambos os fatores de produção, qt $<0$ e nqt $<0$. O Centro-Oeste apresentou abundância relativa em mão-de-obra não qualificada, pois qt/nqt > qc/nqc, ou seja, suas importações líquidas foram relativamente mais intensivas em mão-de-obra qualificada, em relação ao seu consumo doméstico. O teorema de Heckscher-Ohlin foi constatado, pois se pôde verificar que as exportações utilizaram em seu processo produtivo, um volume relativamente maior de mão-de-obra não qualificada em relação às importações, qe/nqe<qi/nqi. 


\begin{tabular}{|c|c|c|c|c|}
\hline $\begin{array}{l}\text { Fatores de } \\
\text { produção }\end{array}$ & $\begin{array}{r}\text { Exportação } \\
\text { (e) }\end{array}$ & $\begin{array}{r}\text { Importação } \\
\text { (i) }\end{array}$ & $\begin{array}{l}\text { Exportação } \\
\text { Liquida }^{1}(\mathrm{t})\end{array}$ & $\begin{array}{l}\text { Consumo } \\
\text { doméstico (c) }\end{array}$ \\
\hline \multicolumn{5}{|c|}{ Asia } \\
\hline Não qualificada (nq) & 20.577 & 10.299 & 10.278 & 2.349 .214 \\
\hline Qualificada (q) & 2.552 & 4.670 & -2.118 & 1.150 .919 \\
\hline Relativo (q/nq) & 0,1240 & 0,4534 & $-0,2061$ & 0,4899 \\
\hline \multicolumn{5}{|c|}{ Estados Unidos } \\
\hline Não qualificada (nq) & 8.551 & 25.501 & -16.950 & 2.349 .214 \\
\hline Qualificada (q) & 1.626 & 17.374 & -15.748 & 1.150 .919 \\
\hline Relativo (q/nq) & 0,1902 & 0,6813 & 0,9291 & 0,4899 \\
\hline \multicolumn{5}{|c|}{ Mercosul } \\
\hline Não qualificada (nq) & 6.968 & 13.637 & -6.669 & 2.349 .214 \\
\hline Qualificada (q) & 1.264 & 1.907 & -643 & 1.150 .919 \\
\hline Relativo (q/nq) & 0,1814 & 0,1399 & 0,0965 & 0,4899 \\
\hline \multicolumn{5}{|c|}{ União Européia } \\
\hline Não qualificada (nq) & 87.337 & 31.462 & 55.876 & 2.349 .214 \\
\hline Qualificada (q) & 10.812 & 16.556 & -5.744 & 1.150 .919 \\
\hline Relativo (q/nq) & 0,1238 & 0,5262 & $-0,1028$ & 0,4899 \\
\hline \multicolumn{5}{|c|}{ Resto do mundo } \\
\hline Não qualificada (nq) & 15.673 & 10.586 & 5.088 & 2.349 .214 \\
\hline Qualificada (q) & 2.247 & 5.559 & -3.312 & 1.150 .919 \\
\hline Relativo (q/nq) & 0,1433 & 0,5251 & $-0,6510$ & 0,4899 \\
\hline
\end{tabular}

Quadro 3 - Utilização dos fatores de produção no comércio do Centro-Oeste com seus principais parceiros no mercado internacional, no ano de 1999.

Fonte: Resultados da pesquisa

${ }^{1}$ Exportação-importação

O Centro-Oeste foi importador líquido de ambos os fatores de produção, no comércio com o Mercosul, nqt $<0$ e qt $<0$. Para que a abundância relativa dos fatores seja definida, deve-se comparar a utilização relativa dos fatores nas importações líquidas e no consumo doméstico. Os resultados do Quadro 3 demonstram que a mão-de-obra qualificada encontrou-se relativamente mais presente no consumo doméstico, em relação às importações líquidas, qt/nqt < qc/nqc. Esse resultado indica que o Centro-Oeste foi importador liquido de mão-de-obra não qualificada e exportador liquido de mão-de-obra qualificada. Assim, a região foi considerada como relativamente abundante em mão-deobra qualificada. Suas exportações para o referido bloco econômico foram relativamente 
mais intensivas em seu fator de produção abundante e as importações mais intensivas em seu fator escasso, qe/nqe>qi/nqi. Dessa forma, pode-se afirmar que o teorema de Heckscher-Ohlin foi válido para o comércio do Centro-Oeste com o Mercosul, de acordo com os resultados do Quadro 3.

A análise do comércio externo realizado no Norte foi baseada nos resultados apresentados no Quadro 4. No comércio com a Ásia, os Estados Unidos e o resto do mundo a região apresentou-se como relativamente abundante em mão-de-obra não qualificada, pois foi exportadora liquida desse fator, nqt $>0$, e importadora liquida da mão-de-obra qualificada, qt $<0$. O teorema de Heckscher-Ohlin foi válido no comércio existente entre a Ásia, os Estados Unidos e o resto do mundo e o Norte, pois as exportações utilizavam relativamente mais de seu fator de produção abundante, mão-deobra não qualificada, e as importações mais de seu fator de produção escasso, mão-deobra qualificada, qe/nqe<qi/nqi.

No caso do comércio observado com o Mercosul, pôde-se constatar que a região foi exportadora liquida de mão-de-obra qualificada, de acordo com os resultados do Quadro 4. Portanto, foi definida como relativamente abundante neste fator de produção, pois, para a mão-de-obra não qualificada, observaram-se importações líquidas, nqt $<0$. Como qe/nqe > qi/nqi, o teorema de Heckscher-Ohlin pôde ser confirmado, pois tanto as exportações quanto às importações se encontraram em conformidade com a dotação relativa de fatores, definida para a região, no comércio com o Mercosul (Quadro 4).

De acordo com os resultados do Quadro 4, o Norte apresentou-se como exportador líquido de ambos os fatores de produção para a União Européia. A região foi considerada como relativamente abundante em mão-de-obra não qualificada, pois as exportações líquidas se apresentaram como relativamente mais intensivas em mão-deobra não qualificada, se comparadas ao consumo doméstico, qt/nqt<qc/nqc. O teorema de Heckscher-Ohlin foi confirmado, pois qe/nqe < qi/nqi, ou seja, as exportações utilizaram, em seu processo produtivo, um volume relativamente maior do fator 
abundante e as importações utilizaram relativamente mais do fator de produção escasso, mão-de-obra qualificada.

\begin{tabular}{|c|c|c|c|c|}
\hline $\begin{array}{l}\text { Fatores de } \\
\text { produção }\end{array}$ & $\begin{array}{l}\text { Exportação } \\
\text { (e) }\end{array}$ & $\begin{array}{l}\text { Importação } \\
\text { (i) }\end{array}$ & $\begin{array}{l}\text { Exportação } \text { Liquida }^{1}(\mathrm{t})\end{array}$ & $\begin{array}{c}\text { Consumo } \\
\text { doméstico (c) }\end{array}$ \\
\hline \multicolumn{5}{|c|}{ Ásia } \\
\hline Não qualificada (nq) & 28.161 & 24.504 & 3.657 & 1.411 .750 \\
\hline Qualificada (q) & 8.981 & 15.572 & -6.592 & 528.569 \\
\hline Relativo (q/nq) & 0,3189 & 0,6355 & $-1,8022$ & 0,3744 \\
\hline \multicolumn{5}{|c|}{ Estados Unidos } \\
\hline Não qualificada (nq) & 23.203 & 13.042 & 10.161 & 1.411 .750 \\
\hline Qualificada (q) & 4.243 & 10.198 & -5.954 & 528.560 \\
\hline Relativo (q/nq) & 0,1829 & 0,7819 & $-0,5860$ & 0,3744 \\
\hline \multicolumn{5}{|c|}{ Mercosul } \\
\hline Não qualificada (nq) & 5.111 & 6.745 & -1.634 & 1.411 .750 \\
\hline Qualificada (q) & 1.459 & 503 & 955 & 528.569 \\
\hline Relativo (q/nq) & 0,2854 & 0,0746 & $-0,5846$ & 0,3744 \\
\hline \multicolumn{5}{|c|}{ União Européia } \\
\hline Não qualificada (nq) & 42.937 & 10.994 & 31.944 & 1.411 .750 \\
\hline Qualificada (q) & 9.460 & 8.580 & 880 & 528.569 \\
\hline Relativo (q/nq) & 0,2203 & 0,7804 & 0,0276 & 0,3744 \\
\hline \multicolumn{5}{|c|}{ Resto do mundo } \\
\hline Não qualificada (nq) & 19.908 & 8.706 & 11.202 & 1.411 .750 \\
\hline Qualificada (q) & 5.034 & 11.700 & -6.666 & 528.569 \\
\hline Relativo (q/nq) & 0,2529 & 1,3440 & $-0,5951$ & 0,3744 \\
\hline
\end{tabular}

Quadro 4 - Utilização dos fatores de produção no comércio do Norte com seus principais parceiros no mercado internacional no ano de 1999.

Fonte: Resultados da pesquisa

${ }^{1}$ Exportação-importação

Os testes de validade do teorema de Heckscher-Ohlin para o comércio verificado entre o Nordeste os blocos econômicos, os Estados Unidos e o resto do mundo, puderam ser realizados com base nos resultados observados no Quadro 5. O Nordeste foi importador líquido dos dois fatores de produção no comércio que realizou com a Ásia, com o Mercosul e com o resto do mundo, qt $<0$ e nqt $<0$. Foi relativamente abundante em mão-de-obra não qualificada no comércio com a Ásia e com o resto do mundo, pois as importações líquidas foram relativamente mais intensivas em mão-de- 
obra qualificada, se comparadas ao consumo doméstico, qt/nqt>qc/nqc. Já no comércio com o Mercosul o fator relativamente mais escasso na região foi a mão-de-obra não qualificada, pois esta se encontrava relativamente mais presente nas importações líquidas, em relação ao consumo doméstico, qt/nqt <qc/nqc. Assim, a região pôde ser considerada, no comércio com o Mercosul, como relativamente abundante em mão-deobra qualificada.

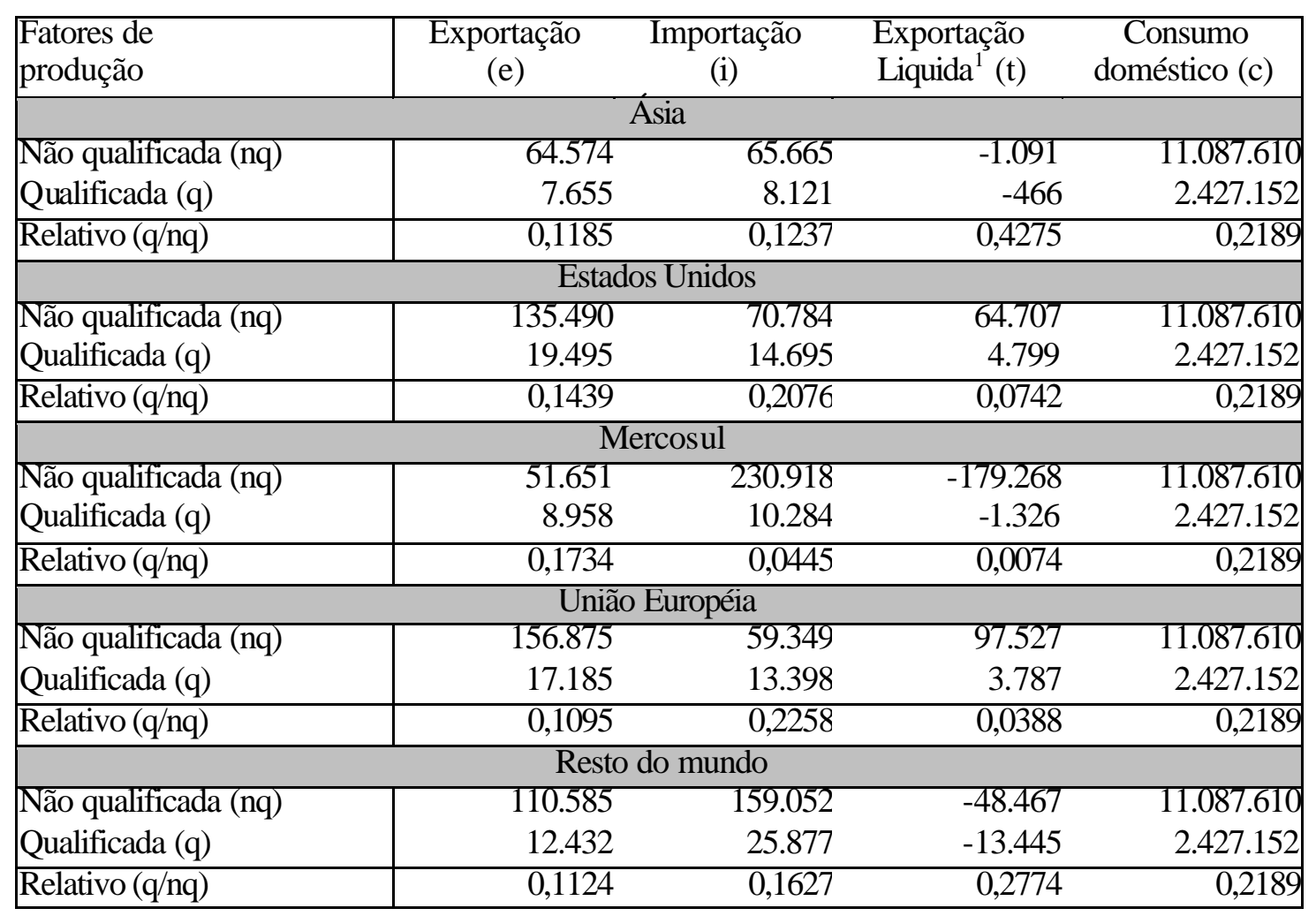

Quadro 5 - Utilização dos fatores de produção no comércio do Nordeste com seus principais parceiros no mercado internacional, no ano de 1999.

Fonte: Resultados da pesquisa

${ }^{1}$ Exportação-importação

A utilização relativa dos fatores de produção na elaboração dos bens e serviços exportados foi mais intensiva em mão-de-obra não qualificada, fator relativamente 
abundante na região no comércio com a Ásia e o resto do mundo. Já nas importações, o inverso foi observado, confirmando assim a validade do teorema de Heckscher-Ohlin no comércio verificado entre o Nordeste e a Ásia e o resto do mundo. Considerando o comércio do nordeste com o Mercosul constatou-se também a validade do teorema de Heckscher-Ohlin, pois a mão-de-obra qualificada encontrou-se mais presente, relativamente, nas exportações em relação às importações, qe/nqe >qi/nqi.

Os resultados apresentados no Quadro 5 mostram que o Nordeste foi exportador líquido de ambos os fatores de produção no comércio realizado com os Estados Unidos e com a União Européia. A região apresentou-se como relativamente abundante em mãode-obra não qualificada, pois qt/nqt < qc/nqc, ou seja, as exportações líquidas foram mais intensivas relativamente na utilização da mão-de-obra não qualificada, em relação ao consumo doméstico. A utilização relativa dos fatores nas exportações e nas importações, qe/nqe<qi/nqi, demonstra que o teorema de Heckscher-Ohlin foi válido para o comércio observado entre o Nordeste e os Estados Unidos e a União Européia.

Os resultados da metodologia descrita no capítulo 4 deste trabalho, aplicada para a região Sul para testar a validade do teorema de Heckscher-Ohlin, encontram-se descritos no Quadro 6. No comércio verificado entre o Sul e a Ásia, os Estados Unidos e a União Européia, a região apresentoutse como exportadora liquida de ambos os fatores, $q \mathrm{t}>0$ e nqt>0. A comparação entre a utilização relativa dos fatores, nas exportações líquidas e no consumo doméstico, demonstrou que, no comércio do Sul com esses parceiros, a região apresentou abundância relativa de mão-de-obra não qualificada, em todos os casos observados, pois qt/nqt < qc/nqc, ou seja, a relação mão-de-obra qualificada e mão-de-obra não qualificada intrínseca nas exportações liquidas foi inferior a relação contida no consumo doméstico.

Para que o teorema de Heckscher-Ohlin fosse confirmado, no comércio do Sul com a Ásia, os Estados Unidos e a União Européia, foi necessário verificar se as exportações e as importações encontravam-se em conformidade com a dotação de fatores observada. De acordo com os dados do Quadro 6, a validade do teorema foi confirmada para o comércio com todos os parceiros analisados, pois qe/nqe < qi/nqi, ou 
seja, as exportações utilizaram de forma mais intensiva, em seu processo produtivo, a mão-de-obra não qualificada, fator definido como abundante na região Sul. Já para as importações, o fator de produção utilizado relativamente em maior volume foi mão-deobra qualificada, fator escasso na região.

\begin{tabular}{|c|c|c|c|c|}
\hline \begin{tabular}{|l} 
Fatores de \\
produção
\end{tabular} & $\begin{array}{l}\text { Exportação } \\
\text { (e) }\end{array}$ & $\begin{array}{l}\text { Importação } \\
\text { (i) }\end{array}$ & $\begin{array}{l}\text { Exportação } \text { Liquida }^{1}(\mathrm{t})\end{array}$ & $\begin{array}{c}\text { Consumo } \\
\text { doméstico (c) }\end{array}$ \\
\hline \multicolumn{5}{|c|}{ Ásia } \\
\hline Não qualificada (nq) & 111.032 & 22.250 & 88.782 & 5.069 .128 \\
\hline Qualificada (q) & 20.624 & 8.697 & 11.927 & 1.993 .874 \\
\hline Relativo (q/nq) & 0,1858 & 0,3909 & 0,1343 & 0,3933 \\
\hline \multicolumn{5}{|c|}{ Estados Unidos } \\
\hline Não qualificada (nq) & 164.043 & 44.870 & 119.173 & 8.995 .518 \\
\hline Qualificada (q) & 34.916 & 19.190 & 15.726 & 3.369 .452 \\
\hline Relativo (q/nq) & 0,2128 & 0,4277 & 0,1320 & 0,3746 \\
\hline \multicolumn{5}{|c|}{ Mercosul } \\
\hline Não qualificada (nq) & 87.934 & 169.083 & -81.149 & 5.069 .128 \\
\hline Qualificada (q) & 27.408 & 40.577 & -13.169 & 1.993 .874 \\
\hline Relativo (q/nq) & 0,3117 & 0,2400 & 0,1623 & 0,3933 \\
\hline \multicolumn{5}{|c|}{ União Européia } \\
\hline Não qualificada (nq) & 309.344 & 76.447 & 232.898 & 5.069 .128 \\
\hline Qualificada (q) & 50.208 & 35.476 & 14.732 & 1.993 .874 \\
\hline Relativo (q/nq) & 0,1623 & 0,4641 & 0,0633 & 0,3933 \\
\hline \multicolumn{5}{|c|}{ Resto do mundo } \\
\hline Não qualificada (nq) & 171.978 & 102.644 & 69.334 & 5.069 .128 \\
\hline Qualificada (q) & 37.882 & 40.809 & -2.927 & 1.993 .874 \\
\hline Relativo (q/nq) & 0,2203 & 0,3976 & $-0,0422$ & 0,3933 \\
\hline
\end{tabular}

Quadro 6 - Utilização dos fatores de produção no comércio do Sul com seus principais parceiros no mercado internacional, no ano de 1999.

Fonte: Resultados da pesquisa

${ }^{1}$ Exportação-importação

Os resultados do Quadro 6 demonstram que apenas no comércio verificado entre o Sul e o Mercosul a região foi considera relativamente abundante em mão-de-obra qualificada, pois as importações líquidas demandaram relativamente um volume maior de mão-de-obra não qualificada, se comparadas ao consumo doméstico, qt/nqt < qc/nqc. A utilização relativa dos fatores na produção dos bens e serviços exportados e 
importados demonstraram que o comércio do Sul com o Mercosul encontra-se em conformidade com o teorema de Heckscher-Ohlin, pois qe/nqe > qi/nqi.

No comércio verificado entre o Sul e o resto do mundo, o fator de produção relativamente abundante foi a mão de obra não qualificada. No Quadro 6, pode-se observar que os sinais das exportações líquidas para os fatores de produção foram opostos, qt $<0$ e nqt $>0$, e, de acordo com Leamer (1984), o que apresentar o sinal positivo é o fator relativamente abundante, no caso a mão-de-obra não qualificada. $O$ teorema de Heckscher-Ohlin foi válido para o comércio verificado entre o Sul e o resto do mundo, pois as exportações e as importações se encontravam de acordo com a dotação de fatores verificada para a região, qe/nqe<qi/nqi.

Os resultados dos testes da validade do teorema de Heckscher-Ohlin no comércio da região Sudeste com o exterior encontram-se descritos no Quadro 7. No comércio estabelecido entre a região, a Ásia e os Estados Unidos, o Sudeste apresentouse como importador líquido de ambos os fatores de produção, qt $<0$ e nqt $<0$. Observando a relação mão-de-obra qualificada e não qualificada, presente nas importações líquidas e no consumo doméstico, pôde-se verificar que essa relação existente nas importações líquidas superou a relação observada no consumo doméstico, qt/nqt>qc/nqc. Assim, a região foi definida como relativamente abundante em mão-de-obra não qualificada, no comércio com a Ásia e com os Estados Unidos. Analisando a razão dos fatores de produção presentes nas exportações e importações, constatou-se a validade do teorema de Heckscher-Ohlin, pois qe/nqe<qi/nqi, ou seja, o fator abundante esteve relativamente presente em maior proporção nas exportações e o fator escasso mais presente nas importações.

No Quadro 7, pode-se observar que, no comércio da região Sudeste com o Mercosul, a região apresentoutse como importadora liquida de mão-de-obra não qualificada e exportadora liquida de mão-de-obra qualificada. Com base nesses resultados, o fator relativamente abundante na região foi à mão-de-obra qualificada. Como a região foi considerada relativamente abundante em mão-de-obra qualificada, espera-se que, nas exportações, esse fator de produção seja utilizado de forma 
relativamente mais intensiva em relação às importações. A hipótese considerada acima foi constatada, pois, no comércio do Sudeste com o Mercosul, qe/nqe>qi/nqi.

\begin{tabular}{|c|c|c|c|c|}
\hline $\begin{array}{l}\text { Fatores de } \\
\text { Produção }\end{array}$ & $\begin{array}{l}\text { Exportação } \\
\text { (e) }\end{array}$ & $\begin{array}{l}\text { Ortação } \\
\text { (i) }\end{array}$ & $\begin{array}{l}\text { Exportação } \text { Liquida }^{1}(\mathrm{t})\end{array}$ & $\begin{array}{c}\text { Consumo } \\
\text { doméstico (c) }\end{array}$ \\
\hline \multicolumn{5}{|c|}{ Asia } \\
\hline Não qualificada (nq) & 121.894 & 122.076 & -181 & 13.462 .471 \\
\hline Qualificada (q) & 42.784 & 63.123 & -20.338 & 5.636 .902 \\
\hline Relativo (q/nq) & 0,3510 & 0,5171 & 112,0968 & 0,4187 \\
\hline \multicolumn{5}{|c|}{ Estados Unidos } \\
\hline Não qualificada (nq) & 222.098 & 247.541 & -25.443 & 21.535 .809 \\
\hline Qualificada (q) & 98.063 & 132.114 & -34.051 & 9.253 .254 \\
\hline Relativo (q/nq) & 0,4415 & 0,5337 & 1,3383 & 0,4297 \\
\hline \multicolumn{5}{|c|}{ Mercosul } \\
\hline Não qualificada (nq) & 129.971 & 190.090 & -60.119 & 13.462 .471 \\
\hline Qualificada (q) & 62.327 & 47.838 & 14.489 & 5.636 .902 \\
\hline Relativo (q/nq) & 0,4795 & 0,2517 & $-0,2410$ & 0,4187 \\
\hline \multicolumn{5}{|c|}{ União Européia } \\
\hline Não qualificada (nq) & 331.655 & 305.316 & 26.339 & 13.462 .471 \\
\hline Qualificada (q) & 103.580 & 158.661 & -55.081 & 5.636 .902 \\
\hline Relativo (q/nq) & 0,3123 & 0,5197 & $-2,0913$ & 0,4187 \\
\hline \multicolumn{5}{|c|}{ Resto do mundo } \\
\hline Não qualificada (nq) & 239.107 & 128.529 & 110.578 & 13.462 .471 \\
\hline Qualificada (q) & 90.808 & 65.747 & 25.061 & 5.636 .902 \\
\hline Relativo (q/nq) & 0,3798 & 0,5115 & 0,2266 & 0,4187 \\
\hline
\end{tabular}

Quadro 7 - Utilização dos fatores de produção no comércio do Sudeste com seus principais parceiros no mercado internacional, no ano de 1999.

Fonte: Resultados da pesquisa

${ }^{1}$ Exportação-importação

No comércio entre o Sudeste e a União Européia, verificou-se que a região apresentou abundância relativa de mão-de-obra não qualificada, pois foi exportadora liquida desse fator de produção, nqt $>0$, e importadora liquida de mão-de-obra qualificada, qt $<0$, de acordo com o Quadro 7. Para que o teorema de Heckscher-Ohlin fosse constatado, as exportações que o Sudeste fez para a União Européia deveriam ser relativamente mais intensivas em mão-de-obra não qualificada e as importações, mais intensivas em mão-de-obra qualificada, fator escasso na região. Os resultados 
apresentados no Quadro 7 permitem a constatação da validade do teorema de Heckscher-Ohlin, pois qe/nqe $<$ qi/nqi.

O Sudeste, de acordo com os dados do Quadro 7, foi exportador líquido de ambos os fatores de produção, no comércio verificado com o resto do mundo. Comparando os resultados relativos obtidos, para as exportações líquidas e para o consumo doméstico, pôde-se constatar que a região foi relativamente abundante em mão-de-obra não qualificada, pois qt/nqt < qc/nqc. Considerando que qe/nqe < qi/nqi, ou seja, a mão-de-obra não qualificada encontou-se mais presente relativamente nas exportações, em relação às importações, o teorema de Heckscher-Ohlin pôde ser considerado como válido.

As seções 5.1.1 e 5.1.2 trazem os resultados dos testes de Heckscher-Ohlin para o comércio externo verificado entre o Brasil e as macrorregiões e seus principais parceiros no mercado mundial: a Ásia, os Estados Unidos, o Mercosul, a União Européia e o resto do mundo. O Quadro 8 mostra um resumo dos testes do teorema realizados para o comércio externo do Brasil e de suas macrorregiões.

De acordo com os resultados apresentados no Quadro 8, pôde-se verificar que, nos 30 testes realizados, o teorema foi confirmado em todos os casos. Com isso, pode-se sugerir que a dotação de fatores explica o comércio observado entre o Brasil e suas macrorregiões e seus principais parceiros no comércio mundial.

Com relação à dotação de fatores definida nos testes realizados, observou-se, nas análises, que as cinco regiões apresentaram um comportamento bastante próximo do observado para o Brasil. Pôde-se, também, verificar que, no comércio observado entre o Brasil e as regiões e a Ásia, os Estados Unidos, a União Européia e o resto do mundo, a dotação constatada diferiu da dotação definida no comércio existente entre o Brasil e o Mercosul. No comércio observado entre o Brasil e os blocos econômicos: Ásia e União Européia, os Estados Unidos e o resto do mundo, o Brasil apresentoutse como relativamente abundante em mão-de-obra não qualificada. Considerando apenas o comércio do país com o Mercosul, pôde-se verificar que o Brasil apresentou-se como relativamente abundante em mão-de-obra qualificada, em todos os tipos de comércio observados com esse bloco econômico. 


\begin{tabular}{|c|c|c|c|c|c|}
\hline $\begin{array}{l}\text { Resultados testes teorema } \\
\text { Heckscher-Ohlin }\end{array}$ & Ásia & $\begin{array}{l}\text { Estados } \\
\text { Unidos }\end{array}$ & Mercosul & $\begin{array}{c}\text { União } \\
\text { Européia }\end{array}$ & $\begin{array}{l}\text { Resto do } \\
\text { mundo }\end{array}$ \\
\hline \multicolumn{6}{|c|}{ Brasil } \\
\hline $\begin{array}{l}\text { Fator abundante } \\
\text { Validade H-O constatada? }\end{array}$ & $\begin{array}{l}\mathrm{nq} \\
\text { sim }\end{array}$ & $\begin{array}{l}\mathrm{nq} \\
\text { sim }\end{array}$ & $\underset{\text { sim }}{\mathrm{q}}$ & $\begin{array}{l}\mathrm{nq} \\
\text { sim }\end{array}$ & $\begin{array}{l}\mathrm{nq} \\
\text { sim }\end{array}$ \\
\hline \multicolumn{6}{|c|}{ Centro-Oeste } \\
\hline $\begin{array}{l}\text { Fator abundante } \\
\text { Validade H-O constatada? }\end{array}$ & $\begin{array}{l}\mathrm{nq} \\
\operatorname{sim}\end{array}$ & $\begin{array}{c}\mathrm{nq} \\
\operatorname{sim}\end{array}$ & $\underset{\operatorname{sim}}{\mathrm{q}}$ & $\begin{array}{c}\mathrm{nq} \\
\operatorname{sim}\end{array}$ & $\begin{array}{c}\mathrm{nq} \\
\operatorname{sim}\end{array}$ \\
\hline \multicolumn{6}{|c|}{ Norte } \\
\hline $\begin{array}{l}\text { Fator abundante } \\
\text { Validade H-O constatada? }\end{array}$ & $\begin{array}{l}\mathrm{nq} \\
\text { sim }\end{array}$ & $\begin{array}{l}\mathrm{nq} \\
\text { sim }\end{array}$ & $\begin{array}{c}\mathrm{q} \\
\operatorname{sim}\end{array}$ & $\begin{array}{l}\mathrm{nq} \\
\text { sim }\end{array}$ & $\begin{array}{l}\mathrm{nq} \\
\operatorname{sim}\end{array}$ \\
\hline \multicolumn{6}{|c|}{ Nordeste } \\
\hline $\begin{array}{l}\text { Fator abundante } \\
\text { Validade H-O constatada? }\end{array}$ & $\begin{array}{l}\mathrm{nq} \\
\text { sim }\end{array}$ & $\begin{array}{c}\mathrm{nq} \\
\operatorname{sim}\end{array}$ & $\begin{array}{c}\mathrm{q} \\
\operatorname{sim}\end{array}$ & $\begin{array}{l}\mathrm{nq} \\
\text { sim }\end{array}$ & $\begin{array}{l}\mathrm{nq} \\
\text { sim }\end{array}$ \\
\hline \multicolumn{6}{|l|}{ 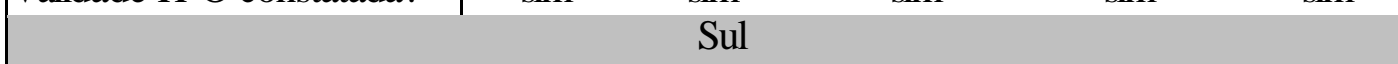 } \\
\hline $\begin{array}{l}\text { Fator abundante } \\
\text { Validade H-O constatada? }\end{array}$ & $\begin{array}{l}\mathrm{nq} \\
\text { sim }\end{array}$ & $\begin{array}{l}\text { nq } \\
\text { sim }\end{array}$ & $\underset{\operatorname{sim}}{\mathrm{q}}$ & $\begin{array}{c}\mathrm{nq} \\
\text { sim }\end{array}$ & $\begin{array}{c}\mathrm{nq} \\
\text { sim }\end{array}$ \\
\hline \multicolumn{6}{|c|}{ Sudeste } \\
\hline $\begin{array}{l}\text { Fator abundante } \\
\text { Validade H-O constatada? }\end{array}$ & $\begin{array}{l}\mathrm{nq} \\
\text { sim }\end{array}$ & $\begin{array}{l}\mathrm{nq} \\
\operatorname{sim}\end{array}$ & $\underset{\text { sim }}{\mathrm{q}}$ & $\begin{array}{c}\mathrm{nq} \\
\text { sim }\end{array}$ & $\begin{array}{c}\mathrm{nq} \\
\text { sim }\end{array}$ \\
\hline
\end{tabular}

Quadro 8 - Resumo dos testes do teorema de Heckscher-Ohlin, realizados para o comércio externo do Brasil e das cinco macrorregiões, em 1999.

Fonte: Resultados da pesquisa

Com base nos resultados acima apresentados, pode-se levantar a hipótese de que o Brasil, no mercado mundial, apresenta comportamento diferenciado no comércio verificado com os países desenvolvidos e em desenvolvimento. A confirmação ou não dessa hipótese requer estudos mais aprofundados. Cabe lembrar que este não é o objetivo central do presente trabalho, mas pode ser observado em trabalhos futuros. $\mathrm{O}$ que se tem nos resultados obtidos neste trabalho é um indicativo de que pode haver diferença no comércio realizado entre os dois blocos de países, desenvolvidos e em desenvolvimento, no que diz respeito à dotação relativa dos fatores de produção. Para que se possa realizar uma análise mais profunda, faz-se necessária a desagregação dos países classificados como resto do mundo neste trabalho. 
Nas seções 5.1.1 e 5.1.2, foram apresentados os resultados dos testes realizados para o teorema de Heckscher-Ohlin no comércio verificado no mercado mundial. A próxima seção tem como objetivo testar a validade do teorema de Heckscher-Ohlin no comércio interno verificado entre as cinco macrorregiões.

\subsubsection{Teste de validade do teorema de Heckscher-Ohlin para o comércio interno, observado entre as macrorregiões}

No teste da validade do teorema de Heckscher-Ohlin, para o comércio realizado internamente entre as macrorregiões em 1999, considerourse a soma da importação que cada uma das regiões fez das outras quatro. Na exportação, consta o total das vendas realizadas pela região para as demais regiões. Os fatores de produção considerados foram: mão-de-obra qualificada e não qualificada. Como consumo doméstico, foi considerada a demanda final da região, destinada ao investimento e ao consumo das famílias e do governo.

A metodologia e o tratamento dos dados encontram-se descritos no capítulo 4. Os procedimentos adotados para a constatação do teorema de Heckscher-Ohlin estão apresentados na eção 3.1.2.3 deste trabalho, e são os mesmos utilizados nas análises do comércio externo.

Os resultados obtidos para as exportações líquidas do Centro-Oeste apresentaram sinais negativos, qt $<0$ e nqt $<0$, de acordo com os dados da Tabela 14. Tal resultado indica que a região foi importadora liquida de ambos os fatores de produção, mão-de-obra qualificada e não qualificada. Para determinar a abundância relativa desses fatores, fez-se necessário comparar a utilização dos fatores na produção da demanda doméstica e na exportação liquida. Considerando que qt/nqt > qc/nqc, o resultado demonstra que a razão mão-de-obra qualificada e não qualificada, presente na importação liquida da região, é superior à relação presente no consumo doméstico. Assim, pode-se dizer que a região Centro-Oeste apresentou abundância relativa de mãode-obra não qualificada. 
Como o Centro-Oeste foi considerado relativamente abundante em mão-deobra não qualificada, esperava-se que suas exportações fossem relativamente mais intensivas em mão-de-obra não qualificada, e as importações relativamente mais intensivas em trabalho qualificado. Como qe/nqe<qi/nqi, o teorema de Heckscher-Ohlin ficou confirmado, para o comércio observado entre o Centro-Oeste e as demais regiões brasileiras, de acordo com os resultados apresentados na Tabela 14.

Tabela 14. Utilização dos fatores de produção no comércio do Centro-Oeste com o resto do Brasil no mercado interno, em 1999.

\begin{tabular}{lrrrr}
\hline Fatores de produção & \multicolumn{1}{c}{$\begin{array}{c}\text { Exportação } \\
\text { (e) }\end{array}$} & $\begin{array}{c}\text { Importação } \\
\text { (i) }\end{array}$ & \multicolumn{1}{c}{$\begin{array}{c}\text { Exportação } \\
\text { liquida }^{1}(\mathrm{t})\end{array}$} & \multicolumn{1}{c}{$\begin{array}{c}\text { Consumo } \\
\text { doméstico (c) }\end{array}$} \\
\cline { 2 - 5 } Não qualificada (nq) & 1.202 .056 & 1.664 .919 & -462.863 & 2.349 .214 \\
Qualificada (q) & 227.054 & 486.155 & -259.101 & 1.150 .919 \\
Relativo (q/nq) & 0,1889 & 0,2920 & 0,5598 & 0,4899 \\
\hline
\end{tabular}

Fonte: Resultados da pesquisa

${ }^{1}$ Exportação-importação

$\mathrm{Na}$ análise da Tabela 15, pode-se verificar que a exportação liquida do Norte foi negativa para a mão-de-obra qualificada, qt $<0$, e não qualificada, nqt $<0$. Dessa forma, a região foi definida como importadora liquida de ambos os fatores. O Norte foi relativamente abundante em mão-de-obra não qualificada, em relação às demais regiões com quem comercializou, pois a relação mão-de-obra qualificada e não qualificada, intrínseca nas importações líquidas, superou a relação intrínseca no consumo doméstico, ou seja, qt/nqt > qc/nqc.

Para comprovar a validade do teorema de Heckscher-Ohlin no comércio do Norte com as demais regiões, fez-se necessário verificar a utilização relativa dos fatores nas importações e exportações. Como a região apresentou abundância relativa em mãode-obra não qualificada, esperava-se que esta estivesse relativamente mais presente em suas exportações, em relação às importações. Na Tabela 15, verifica-se que suas importações foram relativamente mais intensivas em mão-de-obra qualificada, enquanto 
suas exportações foram relativamente mais intensivas em mão-de-obra não qualificada, qe/nqe<qi/nqi. Portanto o teorema de Heckscher-Ohlin foi comprovado para o Norte.

Tabela 15. Utilização dos fatores de produção no comércio do Norte com o resto do Brasil no mercado interno, em 1999.

\begin{tabular}{|c|c|c|c|c|}
\hline Fatores de produção & $\begin{array}{l}\text { Exportação } \\
\text { (e) }\end{array}$ & $\begin{array}{l}\text { Importação } \\
\text { (i) }\end{array}$ & $\begin{array}{l}\text { Exportação } \\
\text { liquida }^{1}(\mathrm{t}) \\
\end{array}$ & $\begin{array}{r}\text { Consumo } \\
\text { doméstico (c) } \\
\end{array}$ \\
\hline Não qualificada (nq) & 728.916 & 876.105 & -147.189 & 1.411 .750 \\
\hline Qualificada (q) & 111.940 & 222.733 & -110.793 & 528.569 \\
\hline Relativo (q/nq) & 0,1536 & 0,2542 & 0,7527 & 0,3744 \\
\hline
\end{tabular}

Fonte: Resultados da pesquisa

${ }^{1}$ Exportação-importação

Na Tabela 16 pode-se observar que o Nordeste foi importador líquido de ambos os fatores de produção, qt $<0$ e nqt $<0$. A região apresentou-se como relativamente abundante em mão-de-obra qualificada, pois a intensidade relativa desse fator, presente nas importações líquidas da região, foi menor que sua intensidade na demanda doméstica, qt/nqt < qc/nqc. Esperava-se, de acordo com o teorema de Heckscher-Ohlin, que suas exportações fossem especializadas em produtos que utilizavam, em seu processo produtivo, um volume relativamente maior de seu fator abundante, no caso a mão-de-obra qualificada. Com base nos resultados da Tabela 16, pôde-se observar que o teorema de Heckscher-Ohlin não foi válido para o Nordeste, pois qe/nqe < qi/nqi.

Tabela 16. Utilização dos fatores de produção no comércio do Nordeste com o resto do Brasil no mercado interno, em 1999.

\begin{tabular}{|c|c|c|c|c|}
\hline Fatores de produção & $\begin{array}{l}\text { Exportação } \\
\text { (e) }\end{array}$ & $\begin{array}{l}\text { Importação } \\
\text { (i) }\end{array}$ & $\begin{array}{r}\text { Exportação } \\
\operatorname{liquida}^{1}(\mathrm{t})\end{array}$ & $\begin{array}{r}\text { Consumo } \\
\text { doméstico (c) }\end{array}$ \\
\hline Não qualificada (nq) & 2.889 .035 & 5.524 .579 & -2.635 .543 & 11.087 .610 \\
\hline Qualificada (q) & 251.355 & 827.042 & -575.687 & 2.427 .152 \\
\hline Relativo (q/nq) & 0,0870 & 0,1497 & 0,2184 & 0,2189 \\
\hline
\end{tabular}

Fonte: Resultados da pesquisa

${ }^{1}$ Exportação-importação 
Considerando-se os resultados apresentados na Tabela 17, pôde-se verificar que o Sul foi importador líquido de mão-de-obra qualificada, qt $<0$, e exportador líquido de mão-de-obra não qualificada, nqt $>0$. Com base nesse resultado, o Sul pôde ser considerado como relativamente abundante em mão-de-obra não qualificada, frente ao comércio observado entre essa região e as demais do Brasil.

Para que o teorema de Heckscher-Ohlin fosse constatado na região Sul, suas exportações deveriam utilizar relativamente um volume maior de seu fator abundante, mão-de-obra não qualificada, e suas importações, um volume relativamente maior de mão-de-obra qualificada. De acordo com os dados da Tabela 17, o teorema de Heckscher-Ohlin foi válido para o Sul, pois qe/nqe < qi/nqi.

Tabela 17. Utilização dos fatores de produção no comércio do Sul com o resto do Brasil no mercado interno, em 1999.

\begin{tabular}{lrrrr} 
Fatores de produção & $\begin{array}{c}\text { Exportação } \\
(\mathrm{e})\end{array}$ & $\begin{array}{c}\text { Importação } \\
\text { (i) }\end{array}$ & $\begin{array}{r}\text { Exportação } \\
\text { liquida }^{1}(\mathrm{t})\end{array}$ & $\begin{array}{r}\text { Consumo } \\
\text { doméstico (c) }^{(1)}\end{array}$ \\
\cline { 2 - 5 } Não qualificada (nq) & 2.599 .586 & 2.129 .332 & 470.254 & 5.069 .128 \\
Qualificada (q) & 553.625 & 765.899 & -212.274 & 1.993 .874 \\
Relativo (q/nq) & 0,2130 & 0,3597 & $-0,4514$ & 0,3933 \\
\hline
\end{tabular}

Fonte: Resultados da pesquisa

${ }^{1}$ Exportação-importação

No Sudeste, como se pode verificar na Tabela 18, as exportações líquidas apresentaram sinais contrários nqt $<0$ e qt $>0$. Esse resultado demonstra que o Sudeste apresentou abundância relativa em mão-de-obra qualificada, pois este fator de produção apresenta sinal positivo nas exportações líquidas. Para que a validade do teorema de Heckscher-Ohlin fosse constatada, o Sudeste deveria especializar-se na produção e na exportação de bens que demandassem um volume maior de seu fator abundante, ou seja, a mão-de-obra qualificada e importar os bens que eram mais intensivos em seu fator escasso, mão-de-obra de menor qualificação. Os dados da Tabela 18 demonstram que para a região Sudeste, o teorema de Heckscher-Ohlin foi válido, pois qe/nqe > qi/nqi. 
Tabela 18. Utilização dos fatores de produção no comércio do Sudeste com o resto do Brasil no mercado interno, em 1999.

\begin{tabular}{|c|c|c|c|c|}
\hline Fatores de produção & $\begin{array}{l}\text { Exportação } \\
\text { (e) }\end{array}$ & $\begin{array}{l}\text { Importação } \\
\text { (i) }\end{array}$ & $\begin{array}{l}\text { Exportação } \\
\text { liquida }^{1}(\mathrm{t})\end{array}$ & $\begin{array}{r}\text { Consumo } \\
\text { doméstico (c) }\end{array}$ \\
\hline Não qualificada (nq) & 2.812 .429 & 3.815 .839 & -1.003 .409 & 13.462 .471 \\
\hline Qualificada (q) & 1.046 .381 & 697.623 & 348.758 & 5.636 .902 \\
\hline Relativo (q/nq) & 0,3721 & 0,1828 & $-0,3476$ & 0,4187 \\
\hline
\end{tabular}

Fonte: Resultados da pesquisa

${ }^{1}$ Exportação-importação

$\mathrm{Na}$ análise dos testes do teorema de Heckscher-Ohlin, realizados para o comércio interno entre as regiões, pôde-se verificar que a validade desse teorema foi confirmada para quatro das cinco regiões consideradas (ver Quadro 9). Somente para o comércio verificado entre o Nordeste e as demais regiões, o teorema não foi constatado. Cabe destacar que, no caso do Nordeste, a razão entre a mão-de-obra qualificada e a não qualificada intrínseca nas exportações líquidas e no consumo doméstico, de acordo com os dados da Tabela 16, somente apresentou diferença na quarta casa decimal. Assim, a definição da abundância relativa dos fatores pode estar "comprometida", pois a diferença verificada foi muito pequena.

\begin{tabular}{|l|c|c|}
\hline Regiões & Fator abundante & $\begin{array}{c}\text { Validade do teorema de H-O } \\
\text { é constatada? }\end{array}$ \\
\hline Norte & Mão-de-obra não qualificada & Sim \\
Nordeste & Mão-de-obra qualificada & Não \\
Centro-Oeste & Mão-de-obra não qualificada & Sim \\
Sul & Mão-de-obra não qualificada & Sim \\
Sudeste & Mão-de-obra qualificada & Sim \\
\hline
\end{tabular}

Quadro 9 - Resumo dos testes do teorema de Heckscher-Ohlin, realizados para o comércio interno das regiões no Brasil, no ano de 1999.

Fonte: Resultados da pesquisa 
A hipótese definida inicialmente no trabalho, de que apenas a região Sudeste seria abundante em mão-de-obra qualificada, fica confirmada com os resultados verificados, salvo resultado observado para o Nordeste, onde o teorema não foi confirmado.

O objetivo da seção 5.1 e de suas sub-seções foi apresentar os resultados dos testes do teorema de Heckscher-Ohlin, para o comércio verificado no mercado doméstico e internacional. Foram analisados os resultados observados para o comércio verificado entre o Brasil e suas regiões e seus principais parceiros comerciais no mercado mundial: Ásia, Estados Unidos, Mercosul, União Européia e o resto do mundo. No comércio interno, foram verificados os resultados obtidos no comércio de cada uma das regiões (Norte, Nordeste, Centro-Oeste, Sul e Sudeste) com as demais. Na seção seguinte, o objetivo é verificar se o comércio intra-indústria foi observado para algum dos tipos de comércio observados nas seções anteriores.

\subsection{Resultados para o comércio intra-indústria}

Os testes realizados nas seções anteriores confirmam a existência do comércio do tipo interindústria, para a maior parte dos casos estudados. Esse tipo de comércio é observado quando há trocas entre setores que não pertencem a um mesmo ramo industrial, por exemplo, se há exportação de produtos primários, as importações devem estar ocorrendo em outros setores, que não os primários. O teorema de Heckscher-Ohlin se aplica a esta categoria de comércio, pois, segundo a pressuposição do mesmo, o país deveria se especializar na produção de bens que requerem, em seu processo produtivo, um volume maior do seu fator de produção abundante e exportá-los, e deveria importar bens que requerem, em seu processo produtivo, um volume maior do seu fator de produção escasso. Dessa forma, de acordo com o teorema de Heckscher-Ohlin, espera-se que as trocas estejam sendo realizadas entre setores pertencentes a ramos diferenciados na situação em que se confirmar o teorema. 
No comércio intra-indústria, a principal característica é o comércio observado entre setores pertencentes a um mesmo ramo industrial. A justificativa, bem como a metodologia empregada para o dimensionamento desse tipo de comércio, foi apresentada na seção 3.1.3 deste trabalho. As Tabelas 19 e 20 trazem os resultados observados para o comércio intra-indústria, nos mercados externo e interno.

Os dados utilizados para efetuar os cálculos foram os mesmos utilizados para testar a validade do teorema de Heckscher-Ohlin. Esses dados, no caso do comércio externo, correspondem às importações e às exportações realizadas com os principais parceiros comercias, no mercado mundial. Os resultados encontram-se descritos na Tabela 19 e demonstram que o comércio intra-indústria foi verificado em apenas três casos, dos 30 que foram analisados.

No comércio que o Brasil realizou no mercado mundial, apenas o seu comércio com o Mercosul foi caracterizado como intra-indústria (62,67\%); para os demais casos, o comércio interindústria prevaleceu. Acredita-se que esse resultado se deva ao comércio verificado entre as regiões Sudeste e Sul e esse bloco, pois foram as únicas regiões que apresentaram um comércio intra-indústria superior a 50\%, no comércio verificado com os principais parceiros comerciais no mercado internacional.

Tabela 19. Dimensionamento do comércio intra-indústria no comércio verificado entre o Brasil e regiões e seus principais parceiros no mercado mundial, no ano de 1999.

\begin{tabular}{lrrrrr}
\hline Regiões & Ésia & $\begin{array}{r}\text { Estados } \\
\text { Unidos }\end{array}$ & Mercosul & $\begin{array}{r}\text { União } \\
\text { Européia }\end{array}$ & $\begin{array}{r}\text { Resto do } \\
\text { mundo }\end{array}$ \\
\cline { 2 - 5 } Brasil & 20,36 & 44,26 & 62,67 & 35,14 & 48,27 \\
Norte & 4,79 & 15,86 & 17,65 & 13,21 & 35,58 \\
Nordeste & 26,31 & 40,42 & 32,63 & 35,90 & 26,92 \\
Centro-Oeste & 5,93 & 3,09 & 41,73 & 6,07 & 16,24 \\
Sudeste & 20,78 & 43,23 & 63,11 & 40,66 & 49,98 \\
Sul & 21,06 & 32,25 & 52,64 & 22,15 & 23,37
\end{tabular}

Fonte: Resultados da pesquisa 
O que se esperaria é que comércio intra-indústria não fosse observado para nenhum dos tipos de comércio internacional analisados no trabalho, pois o teorema de Heckscher-Ohlin foi confirmado em todos esses casos, mas os resultados demonstraram a presença desse tipo de comércio para três casos de comércio com o Mercosul. Cabe destacar que nos testes do teorema de Heckscher-Ohlin o Brasil e as regiões apresentaram abundância relativa, frente ao Mercosul, de mão-de-obra qualificada o que difere dos resultados verificados para os demais parceiros comerciais, analisados. Trabalhos futuros poderão ser realizados buscando uma análise mais detalhada a respeito das relações comerciais existentes entre o Brasil e suas regiões e o Mercosul, onde as explicações para os resultados verificados possam ser encontradas. Vale observar, entretanto, que o comércio externo verificado para as demais regiões pôde ser caracterizado como interindústria, o que confirma os resultados obtidos nos testes do teorema de Heckscher-Ohlin.

Para o dimensionamento do comércio intra-indústria doméstico, foi considerado o comércio que cada uma das regiões realizou com as demais. Os resultados apresentados na Tabela 20 são simétricos, porque as exportações de uma região são importação da outra. Dessa forma, os resultados apresentados do comércio do Norte com o Nordeste são os mesmos resultados obtidos no comércio do Nordeste com o Norte.

Tabela 20. Dimensionamento do comércio intra-indústria no comércio interno observado entre as regiões no Brasil, no ano de 1999.

\begin{tabular}{lcrrrr}
\hline Regiões & Norte & Nordeste & Centro-Oeste & Sudeste & Sul \\
\hline Norte & - & 42,59 & 47,69 & 47,94 & 46,78 \\
Nordeste & 42,59 & - & 55,78 & 40,30 & 38,09 \\
Centro-Oeste & 47,69 & 55,78 & - & 43,61 & 49,87 \\
Sudeste & 47,94 & 40,30 & 43,61 & - & 49,75 \\
Sul & 46,78 & 38,09 & 49,87 & 49,75 & - \\
\hline
\end{tabular}

Fonte: Resultados da pesquisa

Na Tabela 20, pode-se constatar que o comércio interindústria é observado para quase todos os tipos de comércio verificados no mercado doméstico. A exceção é 
observada apenas no comércio verificado entre o Centro-Oeste e o Nordeste. Este pode ser definido como comércio intra-indústria, pois corresponde a 55,78\% das transações verificadas entre as duas regiões. Cabe observar que nos testes realizados para o teorema de Heckscher-Ohlin, este não foi confirmado para o Nordeste. Com isso, os resultados aqui verificados confirmam os observados na seção 5.1.3, ou seja, o comércio interindústria para as transações verificadas entre as regiões Norte, Centro-Oeste, Sudeste e Sul, e comércio intra-indústria para as trocas existentes entre o Nordeste e o Centro-Oeste.

Tanto no que diz respeito que diz respeito ao comércio externo quanto ao comércio interno, pôde-se verificar que o comércio interindústria predominou nas relações comerciais analisadas no presente trabalho, no ano de 1999, confirmando assim a validade do teorema de Heckscher-Ohlin, observada nos comércios interno e externo. 


\section{CONSIDERAÇÕES FINAIS}

O objetivo deste trabalho foi avaliar, com base no padrão de comércio externo e interno brasileiro, se a especialização da produção no Brasil e nas macrorregiões encontra-se de acordo com a dotação relativa de fatores, ou se há outras questões que explicam a localização da produção. A fundamentação teórica veio do teorema de Heckscher-Ohlin, mais especificamente da abordagem da qualificação da mão-de-obra e do comércio intra-indústria. Com base nos resultados verificados para o teorema de Heckscher-Ohlin, pode-se sugerir que a dotação diferenciada de fatores foi importante determinante da especialização da produção, no Brasil e nas regiões, para o comércio no mercado mundial e doméstico. $\mathrm{O}$ dimensionamento do comércio intra-indústria confirma os resultados do teorema de Heckscher-Ohlin para a quase totalidade dos casos analisados.

O teorema de Heckscher-Ohlin foi confirmado para os trinta tipos de comércio externo observados no trabalho, e pôde-se verificar um comportamento semelhante entre os resultados observados para o Brasil, como um todo, e aqueles obtidos para as suas regiões. No comércio entre o Brasil e as regiões e a Ásia, os Estados Unidos, a União Européia e o resto do mundo, a dotação de fatores constatada difere, em sua totalidade, da dotação definida no comércio existente entre o Brasil e suas regiões e o Mercosul. No primeiro caso, o Brasil e suas regiões se apresentaram como relativamente abundantes em mão-de-obra não qualificada. Considerando apenas o comércio do Brasil e das regiões com o Mercosul, pôde-se verificar que o Brasil e as mesmas apresentaram abundância relativa em mão-de-obra qualificada, em todos os tipos de comércio com aquele bloco econômico. 
Os resultados obtidos para o Mercosul não confirmam a hipótese inicial deste trabalho, segundo a qual o Brasil e suas macrorregiões, frente ao comércio com o exterior, seriam relativamente abundantes em mão-de-obra não qualificada. Uma possível explicação para esse resultado pode estar relacionada à pauta de exportação e importação do Brasil e suas regiões para o Mercosul ser diferente da observada para os demais parceiros, no mercado internacional.

Com relação aos resultados observados para o comércio intra-indústria, dos 30 dimensionamentos efetuados para o comércio exterior, apenas em três casos o comércio interindústria não foi observado: no comércio do Brasil, do Sudeste e do Sul com o Mercosul. Pode-se concluir, então, que, na relação entre o Brasil e as macrorregiões e seus principais parceiros comerciais no mercado mundial, o comércio interindústria foi observado na maior parte dos casos, confirmando, assim, os resultados verificados no teorema de Heckscher-Ohlin.

Duas possíveis explicações podem ser sugeridas para os resultados obtidos, no presente trabahho, com relação ao Mercosul. Pode-se sugerir que o Brasil no mercado mundial, apresenta comportamento diferenciado no comércio com os países desenvolvidos e aqueles em desenvolvimento. A confirmação dessa hipótese requer estudos mais aprofundados. O que se tem, nos resultados obtidos neste trabalho, é um indicativo de que pode haver diferença no comércio realizado entre esses dois blocos de países, desenvolvidos e em desenvolvimento, no que diz respeito à dotação relativa dos fatores de produção. Para que se possa realizar uma análise mais profunda, faz-se necessária uma desagregação maior dos países e uma reclassificação dos mesmos em desenvolvidos e não desenvolvidos, para que os testes possam ser realizados para esses dois grupos. O que se priorizou, neste trabalho, foi o comércio do Brasil e suas regiões com os seus principais parceiros e, entre estes, há representantes dos dois blocos de países, desenvolvidos e em fase de desenvolvimento econômico. Em trabalhos futuros, novos testes poderão ser realizados levando em consideração, de um lado, os paises desenvolvidos e, de outro, os países em desenvolvimento. 
A outra explicação possível para os resultados observados pode estar relacionada ao fato de o Brasil apresentar um comércio diferenciado com o Mercosul em relação aos demais países e blocos com os quais comercializa. Essa diferença pode decorrer de o Brasil também fazer parte do referido bloco econômico. Trabalhos futuros terão como objetivo analisar em mais detalhes as relações comerciais entre o Brasil e suas macrorregiões e o Mercosul. Essa análise poderá ser realizada setorialmente e, com isso, pode-se verificar os setores que apresentam o comércio intra-indústria com maior intensidade e com mão-de-obra qualificada mais presente.

$\mathrm{Na}$ análise dos testes do teorema de Heckscher-Ohlin realizados para o comércio interno entre as regiões do Brasil, pôde-se verificar que a validade do teorema foi confirmada para quatro das cinco regiões consideradas. Somente para o comércio entre o Nordeste e as demais regiões, o teorema não foi constatado. Cabe destacar que, no caso do Nordeste, a razão entre a mão-de-obra qualificada e a não qualificada intrínseca nas exportações líquidas e no consumo doméstico somente apresentou diferença na quarta casa decimal. Assim, a definição da abundância relativa dos fatores pode estar "comprometida", pois a diferença verificada foi muito pequena.

Os resultados obtidos para o Nordeste sugerem que a realidade da economia da região difere da observada para o comércio. O Nordeste, como se pôde verificar no capítulo dois desse trabalho, apresentou os maiores percentuais de mão-de-obra de baixa qualificação no país e também as menores remunerações. O resultado do teste do teorema de Heckscher-Ohlin demonstra que a região foi relativamente abundante em mão-de-obra qualificada, mas o teorema não foi confirmado para a região. Uma possível explicação pode estar relacionada ao fato da realidade da dotação de fatores da região não estar refletida em seu comércio. A justificativa para tal explicação encontrase no fato de o setor de refino de petróleo ser a principal fonte de superávit comercial na região (Tabela 12). Esse setor apresenta um dos maiores índices de qualificação da mãode-obra para a região, de acordo com o IBGE (1999b).

A hipótese definida inicialmente no trabalho, de que apenas a região Sudeste seria abundante em mão-de-obra qualificada, fica confirmada com os resultados 
verificados, salvo resultado observado para o Nordeste, para o qual o teorema não foi confirmado.

O comércio intra-indústria somente foi observado, no mercado doméstico entre macrorregiões para as relações comerciais do Nordeste com o Centro-Oeste. Cabe observar que o teorema de Heckscher-Ohlin também não pôde ser constatado para o Nordeste.

Destaca-se a importância do teorema de Heckscher-Ohlin na explicação das relações comerciais externas e internas do Brasil e de suas macrorregiões. Esse é um importante referencial teórico na explicação da especialização da produção no Brasil e em suas macrorregiões. Trabalhos futuros poderão ser realizados para testar a validade do teorema de Heckscher-Ohlin utilizando outros fatores de produção e até mesmo desagregando os fatores utilizados nesse trabalho para três níveis de qualificação.

O que se pode sugerir com relação aos resultados obtidos nesse trabalho é uma maior desconcentração regional das relações comerciais, que, como se pôde verificar, encontra-se muito concentrada nas regiões Sudeste e Sul do Brasil. Políticas públicas que tenham como objetivo incentivar o comércio externo devem levar em consideração as vantagens comparativas que o Brasil apresenta em relação aos seus principais parceiros no mercado mundial. Com isso não se pretende estimular a utilização de mãode-obra não qualificada nos setores exportadores para a Ásia, os Estados Unidos, a União Européia e o resto do mundo e a utilização de mão-de-obra qualificada nos setores exportadores para o Mercosul. O que se sugere é que as políticas públicas devam ser mais direcionadas no sentido aumentar a qualificação da mão-de-obra no Brasil e nas regiões, para que nossa vantagem comparativa no mercado internacional não seja mais de mão-de-obra não qualificada, mas sim de qualificada. Políticas mais direcionadas à educação podem não somente melhorar a qualidade da mão-de-obra, mas também melhorar a qualidade de vida das gerações futuras, que poderão estar mais preparadas para a concorrência no mercado mundial. 
ANEXOS 
ANEXO A - Forma de agregação dos 90 setores existentes nas matrizes construídas por Guilhoto et al., op. cit. (2003) em 31 setores considerados no trabalho.

\begin{tabular}{|c|c|c|c|}
\hline 1 & Cana-de-açúcar & 1 & \\
\hline 2 & Soja & 1 & \\
\hline 3 & Milho & 1 & \\
\hline 4 & Fruticultura & 1 & \\
\hline 5 & Outras culturas & 1 & \\
\hline 6 & Aves & 1 & \\
\hline 7 & Bovinos & 1 & \\
\hline 8 & Suínos & 1 & \\
\hline 9 & Outros pecuária & 1 & \\
\hline 10 & Extrativismo vegetal & 1 & \\
\hline 11 & Silvicultura & 1 & \\
\hline 12 & Extrativismo animal (pesca) & 1 & Agropecuária \\
\hline 13 & Extrativa mineral & 2 & Extrativa mineral (exceto combustíveis) \\
\hline 14 & Petróleo e outros & 3 & Extração de petróleo e gás natural, \\
\hline 15 & Gás natural & 3 & carvão e outros combustíveis \\
\hline 16 & Carvão mineral & 3 & \\
\hline 17 & Mineral ñ metálico & 4 & Minerais não metálicos \\
\hline 18 & Siderurgia & 5 & \\
\hline 19 & Metalúrgicos não ferrosos & 5 & \\
\hline 20 & Outros metalúrgicos & 5 & Siderurgia e metalúrgicos ferrosos ou não \\
\hline 21 & Máquinas e implementos agrícolas & 6 & Fabricação e manutenção de máquinas \\
\hline 22 & Outras máquinas e equipamentos & 6 & e tratores \\
\hline 23 & Material elétrico & 7 & \\
\hline 24 & Equipamentos eletrônicos & 7 & Material elétrico e eletrônicos \\
\hline 25 & Automóveis & 8 & \\
\hline 26 & Caminhões e ônibus & 8 & \\
\hline 27 & Peças e outros veículos & 8 & Automóveis, caminhões, outros veículo e peças \\
\hline 28 & Indús tria da madeira & 9 & \\
\hline 29 & Indústria do mobiliário & 9 & \\
\hline 30 & Fabricação de celulose e pasta mecânica & 9 & Madeira, mobiliário, celulose e pasta \\
\hline 31 & Fabricação de papel, papelão e artefatos de pape & 10 & \\
\hline 32 & Indústria editorial e gráfica & 10 & Indústria de papel e gráfica \\
\hline 33 & Indústria da borracha & 11 & Indústria da borracha \\
\hline 34 & Álcool & 12 & \\
\hline 35 & Outros elementos químicos & 12 & Químicos diversos \\
\hline 36 & Refino do petróleo & 13 & Refino do petróleo \\
\hline 37 & Adubos e fertilizantes & 12 & \\
\hline 38 & Químicos diversos & 12 & \\
\hline 39 & Farmacêutica e veterinária & 14 & Farmacêutica e veterinária \\
\hline 40 & Artigos plásticos & 15 & Artigos plásticos \\
\hline 41 & Indústria Têxtil & 16 & Indústria têxtil \\
\hline 42 & Artigos do vestuário & 17 & Artigos vestuário \\
\hline 43 & Fabricação calçados & 18 & Fabricação calçados \\
\hline 44 & Indústria do café & 19 & \\
\hline 45 & Beneficiamento e outros produtos vegetais & 19 & \\
\hline 46 & Abate de aves & 19 & \\
\hline 47 & Abate de bovinos & 19 & \\
\hline 48 & Abate de suínos e outros & 19 & \\
\hline 49 & Indústria de laticínios & 19 & Produtos alimentares \\
\hline 50 & Fabricação de açúcar & 19 & \\
\hline
\end{tabular}


ANEXO A - Forma de agregação dos 90 setores existentes nas matrizes construídas por Guilhoto et al., op. cit. (2003) em 31 setores considerados no trabalho.

\begin{tabular}{|c|c|c|c|}
\hline & & \\
\hline 51 & Fabricação óleos vegetais & 19 & \multirow{4}{*}{ Produtos alimentares } \\
\hline 52 & Rações & 19 & \\
\hline 53 & Outros produtos alimentares & 19 & \\
\hline 54 & Bebidas & 19 & \\
\hline 55 & Indústrias diversas & 20 & \\
\hline 56 & Produtos energia elétrica hidráulica & 21 & \\
\hline 57 & Produtos energia elétrica óleo combustível & 21 & \\
\hline 58 & Produtos energia elétrica carvão & 21 & \\
\hline 59 & Produtos energia óleo diesel & 21 & \\
\hline 60 & Produtos energia elétrica gás natural & 21 & \\
\hline 61 & Produtos energia outras fontes & 21 & \\
\hline 62 & Distribuição de energia elétrica & 21 & \\
\hline 63 & Saneamento e abastecimento d'água & 21 & \\
\hline 64 & Coleta e tratamento de lixo & 21 & Indústrias diversas \\
\hline 65 & Construção civil & 22 & Construção civil \\
\hline 66 & Atacado & 23 & \\
\hline 67 & Varejo de combustíveis & 23 & \\
\hline 68 & Varejo de veículos e peças & 23 & \\
\hline 69 & Supermercados & 23 & \\
\hline 70 & Outras lojas do varejo & 23 & Comércio \\
\hline 71 & Transporte rodoviário & 24 & \\
\hline 72 & Transporte aéreo & 24 & \\
\hline 73 & Transporte ferroviário & 24 & \\
\hline 74 & Transporte aquaviário & 24 & \\
\hline 75 & Atividades auxiliares dos transportes & 24 & Transporte \\
\hline 76 & Telefonia móvel & 25 & \\
\hline 77 & Telefonia fixa & 25 & \\
\hline 78 & Correios & 25 & Comunicações \\
\hline 79 & Instituições financeiras & 26 & Instituições financeiras \\
\hline 80 & Saúde mercantil & 27 & \\
\hline 81 & Educação mercantil & 27 & \\
\hline 82 & Alojamento e alimentação & 27 & \\
\hline 83 & Outros serviços prestados à família & 27 & Serviços prestados às famílias \\
\hline 84 & Serviços prestados às empresas & 28 & Serviços prestados às empresas \\
\hline 85 & Aluguel de imóveis & 29 & Aluguel imóveis \\
\hline 86 & Saúde pública & 30 & \\
\hline 87 & Educação pública & 30 & \\
\hline 88 & Segurança pública & 30 & \\
\hline 89 & Outras atividades da administração pública & 30 & Administração pública \\
\hline 90 & Serviços privados não mercantis & 31 & Serviços Privados não mercantis \\
\hline
\end{tabular}


ANEXO B - Compatibilização atividades da PNAD e da matriz insumo produto .

\begin{tabular}{|c|c|c|c|}
\hline & Atividades da matriz insumo-produto & Setores & Código de atividade da PNAD \\
\hline 1 & Agropecuária & 1 & 011 a $037,041,042$ e 581 \\
\hline 2 & Extrativa mineral (exceto combustíveis) & 2 & 050 e 053 a 059 \\
\hline 3 & Extração de petróleo e gás natural, carvão e outros combustíveis & 3 & 051 e 052 \\
\hline 4 & Fabricação de minerais não metálicos & 4 & 100 \\
\hline 5 & Siderurgia & & 110 \\
\hline 6 & Metalurgia dos não-ferrosos & & 110 \\
\hline 7 & Fabricação de outros produtos metalúrgicos & 5 & 110 \\
\hline 8 & Fabricação e manutenção de máquinas e tratores & 6 & 120 \\
\hline 9 & Fabricação de aparelhos e equipamentos de material elétrico & & 130 \\
\hline 10 & Fabricação de aparelhos e equipamentos de material eletrônico & 1 & 130 \\
\hline 11 & Fabricação de automóveis, caminhões e ônibus & & 140 \\
\hline 12 & Fabricação de outros veículos, peças e acessórios & ४ & 140 \\
\hline 13 & Serrarias e fabricação de artigos de madeira e mobiliário & 9 & 150,151 e 160 \\
\hline 14 & Indústria de papel e gráfica & 10 & 170 e 290 \\
\hline 15 & Indústria da borracha & 11 & 180 \\
\hline 16 & Fabricação de elementos químicos não-petroquímicos & 12 & 200 \\
\hline 17 & Refino de petróleo e indústria petroquímica & 13 & $201,202,352$ e 477 \\
\hline 18 & Fabricação de produtos químicos diversos & 12 & 200 \\
\hline 19 & Fabricação de produtos farmacêuticos e de perfumaria & 14 & 210 e 220 \\
\hline 20 & indústria de transformação de material plástico & 15 & 230 \\
\hline 21 & Indústria têxtil & 16 & 240 e 241 \\
\hline 22 & Fabricação de artigos do vestuário e acessórios & 17 & 250 e 532 \\
\hline 23 & Fabricação de calçados e de artigos de couro e peles & 18 & 190 e 251 \\
\hline 24 & Indústria do café & & $260,261,270$ e 280 \\
\hline 25 & Beneficiamento de produtos de origem vegetal inclusive fumo & & $260,261,270$ e 280 \\
\hline 26 & Abate e preparação de carnes & & $260,261,270$ e 280 \\
\hline 27 & Refinamento e preparação do leite e laticínios & & $260,261,270$ e 280 \\
\hline 28 & Indústria do açúcar & & $260,261,270$ e 280 \\
\hline 29 & $\begin{array}{l}\text { Fabricação e refino de óleos vegetais e de gorduras para a } \\
\text { alimentação }\end{array}$ & & $260,261,270$ e 280 \\
\hline 30 & Outras indústrias alimentares e de bebidas & iy & $260,261,270$ e 280 \\
\hline 31 & Indústrias diversas & 20 & 300 \\
\hline 32 & Serviços industriais de utilidade pública & 21 & 351 e 353 \\
\hline 33 & Construção civil & 22 & 340 e 524 \\
\hline 34 & Comércio & 23 & 410 a 424,582 e 583 \\
\hline 35 & Transporte & 24 & 471 a 476 e 588 \\
\hline 36 & Comunicações & 25 & 481 e 482 \\
\hline 37 & Instituições financeiras & 26 & 451 a 453,585 e 612 \\
\hline 38 & Serviços prestados às famílias & 21 & $\begin{array}{c}463,511,512,521 \text { a } 523,525,531 \\
533,541,542,545,551,577,586,587 \\
622 \text { a } 624,632,801,901 \text { e } 902\end{array}$ \\
\hline 39 & Serviços prestados às empresas & 28 & $462,464,543,552,571$ a $576,578,584$ a 589 \\
\hline 40 & Aluguel de imóveis & 29 & 461 e 584 \\
\hline 41 & Administração pública & 30 & $354,610,611,621,631,711$ a 717 e 721 a 727 \\
\hline 42 & Serviços privados não-mercantis & 31 & 544 e 613 a 619 \\
\hline
\end{tabular}

Fonte: Adaptado de IBGE (1997) 
ANEXO C - Agregação dos 141 produtos, considerados em Guilhoto et al., op. cit. (2003), em 31 setores.

\begin{tabular}{|c|c|c|}
\hline & Produtos & Agregação setores \\
\hline 1 & Café em coco & \\
\hline 2 & Cana-de-açúcar & \\
\hline 3 & Arroz em casca & \\
\hline 4 & Trigo em grão & \\
\hline 5 & Soja em grão & \\
\hline 6 & Algodão em caroço & \\
\hline 7 & Milho em grão & \\
\hline 8 & Cacau & \\
\hline 9 & Feijão & \\
\hline 10 & Mandioca & \\
\hline 11 & Laranja & \\
\hline 12 & Outros da fruticultura & \\
\hline 13 & Outras culturas & \\
\hline 14 & Bovinos & \\
\hline 15 & Suínos & \\
\hline 16 & Leite natural & \\
\hline 17 & Aves vivas e ovos frescos & \\
\hline 18 & Outros pecuária & \\
\hline 19 & Madeira em tora & \\
\hline 20 & Outros produtos extrativa vegetal & \\
\hline 21 & Tora para papel e celulose & \\
\hline 22 & Tora para outras finalidades & \\
\hline 23 & Outros produtos florestamento & \\
\hline 24 & Produtos extrativa animal & 1- Agropecuária \\
\hline 25 & Minério de ferro & \\
\hline 26 & Minério de alumínio & \\
\hline 27 & Calcário & \\
\hline 28 & Outros minerais & 2 Extrativa mineral (exceto combustíveis) \\
\hline 29 & Petróleo outros & \\
\hline 30 & Gás natural & \\
\hline 31 & Carvão mineral & 3 Extração de petróleo, gás, carvão e outros \\
\hline 32 & Cimento e artefatos & \\
\hline 33 & Cerâmica para construção & \\
\hline 34 & Outros produtos minerais ñ metálicos & 4 Minerais não metálicos \\
\hline 35 & Produtos siderúrgicos básicos & \\
\hline 36 & Laminados de aço & \\
\hline 37 & Alumínio & \\
\hline 38 & Outros produtos metalúrgicos não ferrosos & \\
\hline 39 & Outros produtos metalúrgicos & 5 Siderurgia e metalúrgicos ferrosos ou não \\
\hline
\end{tabular}


ANEXO C - Agregação dos 141 produtos, considerados em Guilhoto et al., op. cit. (2003), em 31 setores.

\begin{tabular}{|c|c|c|}
\hline 40 & $\begin{array}{l}\text { Máquinas e implementos agrícolas } \\
\text { Máquinas e implementos não agrícolas }\end{array}$ & $\begin{array}{l}6 \text { Fabricação e manutenção de máquinas e } \\
\text { tratores }\end{array}$ \\
\hline 42 & Equipamentos para geração, transmissão e & \\
\hline 43 & Outros materiais elétricos & \\
\hline 44 & Equipamentos para telecomunicações & \\
\hline 45 & Outros equipamentos eletrônicos & 7 Material elétrico e eletrônico \\
\hline 46 & Automóveis & \\
\hline 47 & Caminhões e ônibus & \\
\hline 48 & Outros veículos e peças & 8 Automóveis, outros veículos e peças \\
\hline 49 & Painéis & \\
\hline 50 & Madeira serrada e artigos de madeira (não painéis), & \\
\hline 51 & Móveis de madeira & \\
\hline 52 & Outros móveis e colchoaria & 9 Madeira mobiliário \\
\hline 53 & Celulose e pasta mecânica & \\
\hline 54 & Papel, papelão e artefatos & \\
\hline 55 & Serviços gráficos e editoriais & 10 Indústria de papel e gráfica \\
\hline 56 & Produtos da borracha & 11 Indústria da borracha \\
\hline 57 & Álcool de cana e cereais & \\
\hline 58 & Elementos químicos não petroquímicos & 12 Químicos diversos \\
\hline 59 & Gasolina pura & \\
\hline 60 & Óleo diesel & \\
\hline 61 & Óleos combustíveis & \\
\hline 62 & GLP & \\
\hline 63 & Combustíveis para aviação & \\
\hline 64 & Outros produtos do refino & 13 Refino de petróleo \\
\hline 65 & Produtos petroquímicos básicos & \\
\hline 66 & Resinas & \\
\hline 67 & Gasoálcool & \\
\hline 68 & Adubos & \\
\hline 69 & Tintas & \\
\hline 70 & Outros produtos químicos & 12 Químicos diversos \\
\hline 71 & Farmacêuticos & \\
\hline 72 & Farmacêuticos de uso veterinário & \\
\hline 73 & Perfumaria e cosméticos & \\
\hline 74 & Limpeza doméstica e outros & 14 Farmacêutica e veterinária \\
\hline 75 & Artigos de plástico & 15 Artigos de plástico \\
\hline 76 & Fios têxteis naturais & \\
\hline 77 & Tecidos naturais & \\
\hline 78 & Fios têxteis artificiais & \\
\hline 79 & Tecidos artificiais & 16 Indústria têxtil \\
\hline
\end{tabular}


ANEXO C - Agregação dos 141 produtos, considerados em Guilhoto et al., op. cit. (2003), em 31 setores.

\begin{tabular}{|c|c|c|}
\hline 80 & Outros produtos têxteis & 16 Indústria têxtil \\
\hline 81 & Artigos do vestuário & 17 Artigos vestuário \\
\hline 82 & Produto couro e calçados & 18 Fabricação do calçados \\
\hline 83 & Produtos do café & \\
\hline 84 & Arroz beneficiado & \\
\hline 85 & Farinha de trigo & \\
\hline 86 & Milho beneficiado & \\
\hline 87 & Cacau beneficiado & \\
\hline 88 & Laranja beneficiada & \\
\hline 89 & Outros produtos alimentares beneficiados & \\
\hline 90 & Carne de aves abatidas & \\
\hline 91 & Carne bovina & \\
\hline 92 & Carne suínos & \\
\hline 93 & Carne outros & \\
\hline 94 & Leite beneficiado & \\
\hline 95 & Outros laticínios & \\
\hline 96 & Açúcar & \\
\hline 97 & Óleo de soja em bruto & \\
\hline 98 & Outros óleos vegetais em bruto & \\
\hline 99 & Óleo de soja refinado & \\
\hline 100 & Outros óleos vegetais refinados & \\
\hline 101 & Rações & \\
\hline 102 & Outros alimentos & \\
\hline 103 & Bebidas & 19 Produtos alimentares \\
\hline 104 & Produtos diversos & 20 Indústrias diversas \\
\hline 105 & Produtos energia elétrica hidráulica & \\
\hline 106 & Produtos energia elétrica óleo combustível & \\
\hline 107 & Produtos energia elétrica carvão & \\
\hline 108 & Produtos energia elétrica óleo diesel & \\
\hline 109 & Produtos energia elétrica gás natural & \\
\hline 110 & Energia de outras fontes & \\
\hline 111 & Distribuição de energia elétrica & \\
\hline 112 & Saneamento e abastecimento d'água & \\
\hline 113 & Coleta e tratamento de lixo & 21 SIUP \\
\hline 114 & Construção civil & 22 Construção civil \\
\hline 115 & Comércio atacadista & \\
\hline 116 & Comércio varejista de combustíveis & \\
\hline 117 & Comércio varejista de veículos, peças e acessórios & \\
\hline 118 & Supermercados & \\
\hline 119 & Outros comércios varejistas & 23 Comércio \\
\hline
\end{tabular}


ANEXO C - Agregação dos 141 produtos, considerados em Guilhoto et al., op. cit. (2003), em 31 setores.

\begin{tabular}{|c|c|c|}
\hline 112 & Trancnorte rodoviário & \\
\hline $\mid 20$ & Trancnorte aéreo & \\
\hline 122 & Transporte ferroviário & \\
\hline 123 & Transporte hidroviário & \\
\hline 124 & Atividades auxiliares do transporte & 24 Transporte \\
\hline 125 & Serviços de telefonia móvel & \\
\hline 126 & Serviços de telefonia fixa & \\
\hline 127 & Correios & 25 Comunicações \\
\hline 128 & Seguros & \\
\hline 129 & Serviços financeiros & 26 Instituições financeiras \\
\hline 130 & Saúde mercantis & \\
\hline 131 & Educação mercantil & \\
\hline 132 & Alojamento e alimentação & \\
\hline 133 & Outros serviços prestados às famílias & 27 Serviços prestados às famílias \\
\hline 134 & Serviços prestados às empresas & 28 Serviços prestados às empresas \\
\hline 135 & Aluguel de imóveis & \\
\hline 136 & Aluguel imputado & 29 Aluguel imóveis \\
\hline 137 & Saúde pública & \\
\hline 138 & Educação pública & \\
\hline 139 & Segurança pública & \\
\hline 140 & Outras atividades da adm. pública & 30 Administração pública \\
\hline 141 & Serviço não mercantil privado & 31 Serviços privados não mercantis \\
\hline
\end{tabular}




\section{REFERÊNCIAS BIBLIOGRÁFICAS}

ANUÁRIO ESTATÍSTICO DO BRASIL - 2000, v.60, 2002.

AUREA, A.; GALVÃO, A.C.F. Importação de tecnologia, acesso às inovações e desenvolvimento regional: o quadro recente do Brasil. Rio de Janeiro: IPEA, 1998. 37p. (Texto para discussão, 616)

BALDWIN, R.E. Determinants of the commodity structure of U.S. trade. The American Economic Review, v.61, n.1, p.126-146, Mar. 1971.

BOM, R. Comparative stability analysis of multiregional input-output models. The Quarterly Journal of Economics, v.99, n.4, p.791-815, Nov. 1984.

BRASIL. Ministério do Desenvolvimento, da Indústria e Comércio Exterior. Anuário Estatístico, abr. 2002. http://www.desenvolvimento.gov.br (13 maio 2002)

BRASIL. Ministério do Desenvolvimento, da Indústria e Comércio Exterior. Sistema Alice. http://www.mdic.aliceweb.gov.br (20 mar. 2003)

BRASIL. Ministério do Desenvolvimento, da Indústria e Comércio Exterior. Balança Comercial Brasileira. Brasília, jan./dez. 1994.

BRASIL. Ministério do Desenvolvimento, da Indústria e Comércio Exterior. Balança Comercial Brasileira. Brasília, jan./dez. 2000.

BRASIL. Ministério do Trabalho e Emprego. Relação Anual de Informações Sociais RAIS (compact disk). Brasília, 1999. 
CAVALCANTI, J.E.A. Avaliação do padrão de desenvolvimento da economia do Nordeste: 1975-80. Revista Brasileira de Economia, v.48, n.1, p.107-124, jan./mar. 1994.

CARVALHO, M.A.; SILVA, C.R.L. Economia internacional. São Paulo: Saraiva, 2000. 300p.

CROCOMO, F.C. Análise das relações inter-regionais e interssetoriais na economia brasileira em 1985: uma aplicação de insumo-produto. Piracicaba, 1998. 179p. Tese (Doutorado) - Escola Superior de Agricultura "Luiz de Queiroz", Universidade de São Paulo.

GALVÃO, O.J.A. Comércio interestadual por vias internas e integração regional do Brasil: 1943-69. Revista Brasileira de Economia, v.53, n.4, p.523-558, out./dez. 1999.

GONÇALVES, R.; BAUMANN, R.; CANUTO, O.; PRADO, L.C.D. A nova economia internacional: uma perspectiva brasileira. 5.ed. Rio de Janeiro: Campos, 1998, $392 p$.

GREENHALGH, C.; GREGORY, M.; ZISSIMOS, B. The impact of trade technological change and final demand on the skills structure of UK employment. Oxford: University of Oxford, Center for Economic Performance, 1998. (Discussion Paper, 29)

GUILHOTO, J.J.M. Leontief e insumo-produto: antecedentes, princípios e evolução. Piracicaba: ESALQ, Depto. Economia Administração e Sociologia, 2001. 43p. (Série seminários, 15)

HADDAD, P. Métodos de análise de setores-chave e de complexos industriais. In: HADDAD, P. (Org.). Economia regional: teoria e métodos de análise. Fortaleza: BNB/ETENE, 1989. p.399-426.

HANSEN, W.; TIEBOUT, C. An intersectoral flow analysis of the California economy. The Review of Economics and Statistics, v.45, n.20, p.409-418, Nov. 1963. 
HIDALGO, A.B. Mudanças na estrutura do comércio internacional brasileiro: comércio interindústria X comércio intra-indústria. Análise Econômica, v.11, n.20, p.55-68, set. 1993.

INSTITUTO BRASILEIRO DE GEOGRAFIA E ESTATISTICA. Sistema de contas nacionais: tabelas de recursos e usos metodologias. Rio de Janeiro, 1997. 59p. (Texto para discussão, 88)

INSTITUTO BRASILEIRO DE GEOGRAFIA E ESTATISTICA. Pesquisa nacional por amostra de domicílios: PNAD (compact disk). Rio de Janeiro: 1999a.

INSTITUTO BRASILEIRO DE GEOGRAFIA E ESTATISTICA. Pesquisa nacional por amostra de domicílios: microdados. (compact disk). Rio de Janeiro: 1999b.

ISARD, W. Interregional and regional input-output analysis: a model of a spaceeconomy. Review of Economics and Statistics, v.33, p.319-328, 1951.

KEESING, D.B. Labor skill and the structure of trade in manufactures. In: KENEN, P.; LAWRENCE, R. The open economy: essays on international trade and finance. New York: Columbia University Press, 1968. v.60, p.287-294.

KRUGMAN, P.R.; OBSTFELD, M. Economia internacional teoria e política. Trad. C.M.R. Laranjeira. 4.ed. São Paulo: Makron Books, 1999. 807p.

LEAMER, E.E. The Leontief paradox, reconsidered. Journal of Political Economy, v.88, n.3, p.495-503, June 1980.

LEAMER, E.E. Sources of international comparative advantage: theory and evidence. Cambridge: MIT Press, 1984. 353p.

LEAMER, E.E. Paths of development in the three-factor, N-good general equilibrium model. Journal of Political Economy, v.95, n.5, p.961-999, 1987.

LEON, F.L.L.; DOMINGUES, E.P.; HADDAD, E.A. Impacto das exportações sobre a estrutura setorial e de qualificação do emprego no Brasil (compact disc). In: ENCONTRO NACIONAL DE ECONOMIA, 28., Campinas, 2000. Anais. Campinas: ANPEC, 2000. 
LEONTIEF, W. Factor proportions and the structure of american trade: further theorical and empirical analysis. Review of Economic and Statistical, v.38, p.386-407, Nov. 1956.

LEONTIEF, W. Domestic production and foreign trade: the american capital position reexamined. Economia Internazionale, v.7, n.1, p.3-32, Feb. 1953. /Republicado em: CAVES, E.R.; JOHNSON, H.G. Readings in international economics. Illinois: Homewood, 1968/

MACHADO, D.L. A qualificação da mão-de-obra no comércio internacional brasileiro: um teste do Teorema de Heckscher-Ohlin. Rio de Janeiro: BNDES, Departamento de Relações Institucionais, jun. 1997. 97p. (20 prêmio BNDES de economia)

MAIA, K. Progresso tecnológico, qualificação da mão-de-obra e desemprego. Brasília, 2001. 183p. Tese (Doutorado) - Universidade de Brasília.

METZLER, L.A. Multiple-região theory of income and trade. Econometrica, v.18, p.329-354, Oct. 1950.

MILLER, R.E.; BLAIR, P.D. Input-output analysis: foundations and extensions. Englewood Cliffs: Prentice-Hall, 1985. 464p.

MONTOYA M.A.R. A matriz insumo-produto internacional do Mercosul em 1990: a desigualdade regional e o impacto intersetorial do comércio inter-regional. Piracicaba, 1998. 217p. Tese (Doutorado) - Escola Superior de Agricultura "Luiz de Queiroz", Universidade de São Paulo.

MOREIRA, M.M.; NAJBERG, S. Abertura comercial: criando ou exportando empregos ? Rio de Janeiro: IPEA, 1997. 51p. (Texto para discussão, 59)

MORETO, A.C. Relações intersetoriais e inter-regionais na economia paranaense em 1995. Piracicaba, 2000. 161p. Tese (Doutorado) - Escola Superior de Agricultura “Luiz de Queiroz”, Universidade de São Paulo. 
MOSES, L. The stability of interregional trading patterns and input-output analysis. The American Economic Review, v.45, n.5, p.803-832, 1955.

NERI, M.; CAMARGO, J.M.; REIS, M.C. Mercado de trabalho nos anos 90: fatos estilizados e interpretações. Rio de Janeiro: IPEA, 2000. 31p. (Texto para discussão, 743)

PARRÉ, J.L. O agronegócio nas microrregiões brasileiras: 1985 a 1995. Piracicaba, 2000. 191p. Tese (Doutorado) - Escola Superior de Agricultura "Luiz de Queiroz", Universidade de São Paulo.

RICARDO, D. Princípios da economia política e tributação. Trad. de Paulo H. R. Sandroni. São Paulo: Abril Cultural, 1982. 286p.

ROCCA, C.A.; BARROS, J.R.M. Recursos humanos e estrutura do comércio exterior. Estudos Econômicos, v.2 n.5, p.89-110, out. 1972.

RODRIGUES, R.L. Cooperativas agropecuárias e relação intersetorial na economia paranaense: uma análise de insumo-produto. Piracicaba, 2000. Tese (Doutorado) Escola Superior de Agricultura “Luiz de Queiroz”, Universidade de São Paulo.

ROUNDT, J.I. Nonsurvey techniques: a critical review of the theory and the evidence international. Regional Science Review, v.8, n.3, p.189-212, 1983.

SAMUELSON, P.A. International factor-price equalization once again. Economic Journal, v.59, n.234, p.181-197, 1948. /Republicado em: CAVES, E.R.; JOHNSON, H.G. Readings in international economics. Illinois: Homewood, 1968/

SILVA, C.E.L. Como as economias de São Paulo e Minas Gerais se comparam à do resto do Brasil: uma análise das suas estruturas produtivas. Piracicaba, 2001. 108p. Dissertação (Mestrado) - Escola Superior de Agricultura "Luiz de Queiroz", Universidade de São Paulo.

SILVEIRA, S.F.R. Inter-relações econômicas dos estados da bacia do rio São Francisco: uma análise insumo-produto. Piracicaba, 1998. 245p. Tese (Doutorado) - Escola Superior de Agricultura “Luiz de Queiroz”, Universidade de São Paulo. 
SMITH, A. A riqueza das nações: investigação sobre sua natureza e suas causas. Trad. de Winston Fritsh. São Paulo: Abril Cultural, 1983. 350p.

SÖDERSTEN, B.O. Economia internacional. Trad. de Flávio W. Lara. Rio de Janeiro: Interciência, 1979. 533p.

STOLPER, W.; SAMUELSON, P.A. Protection and real wages. Review of Economic Studies, v.9, p.58-73, 1941.

TYLER. W.G. O comércio de manufaturas e a participação do trabalho especializado: o caso brasileiro. Estudos Econômicos, v.2 n.5, p.129-1547, out. 1972.

VANEK, J. The factor proportions theory: the N-factor case. Kyklos, v.21, p.749-756, 1968.

VASCONCELOS, C.R. Análise do padrão do fluxo de comércio externo brasileiro sob a ótica do teorema de Heckscher-Ohlin: o caso do Mercosul e do comércio como resto do mundo. Estudos Econômicos, v.31, n.4, p.615-651, out./dez. 2001.

VASCONCELOS, J.R. Matriz de fluxo de comércio interestadual de bens e serviços no Brasil - 1998. Rio de Janeiro: IPEA, 2001. 81p. (Texto para discussão, 783) 